\section{Pacific Northwest} National Laboratory

Operated by Battelle for the

U.S. Department of Energy

\section{Groundwater Quality Assessment Report for Waste Management Area S-SX (April 2000 through December 2001)}

\author{
V. G. Johnson \\ C. J. Chou
}

February 2002

\author{
Prepared for the U.S. Department of Energy \\ under Contract DE-AC06-76RL01830
}




\title{
Groundwater Quality Assessment Report for Waste Management Area S-SX (April 2000 through December 2001)
}

\author{
V. G. Johnson \\ C. J. Chou
}

February 2002

Prepared for

the U.S. Department of Energy

under Contract DE-AC06-76RL01830

Pacific Northwest National Laboratory

Richland, Washington 99352 


\section{DISCLAIMER}

This report was prepared as an account of work sponsored by an agency of the United States Government. Reference herein to any specific commercial product, process, or service by trade name, trademark, manufacturer, or otherwise does not necessarily constitute or imply its endorsement, recommendation, or favoring by the United States Government or any agency thereof, or Battelle Memorial Institute.

\section{PACIFIC NORTHWEST NATIONAL LABORATORY operated by \\ BATTELLE for the \\ UNITED STATES DEPARTMENT OF ENERGY under Contract DE-AC06-76RL01830}




\section{Preface}

This report was written to comply with the requirements stipulated in the Resources Conservation and Recovery Act (40 CFR 265, Subpart F) and in the State of Washington dangerous waste regulations

(WAC 173-303). These regulations require groundwater monitoring at facilities that treat, store, transfer, and/or dispose of dangerous waste.

The regulated unit addressed in this report is one of seven single-shell tank waste management areas at the Hanford Site located in south central Washington State. The single-shell tanks contain radioactive high-salt defense waste generated during the chemical separation of weapons grade plutonium. Nearly half of the 149 individual single-shell tanks are known or suspected to have leaked. Spills associated with waste transfers within the waste management areas have also occurred. Retrieval, processing, and final disposal and/or stabilization in place of these wastes will take place over the next 30 to 40 years.

Mobile tank waste constituents (e.g., technetium-99, hexavalent chromium, and nitrate) have appeared in some downgradient wells at five of the seven single-shell tank waste management areas. Groundwater and vadose zone characterization activities are underway to evaluate the nature and extent of the subsurface contamination. The groundwater studies at the single-shell tank waste management areas are part of the Hanford Groundwater Monitoring Project conducted by Pacific Northwest National Laboratory for the U.S. Department of Energy. Additional background information and related subsurface conditions at Hanford Site can be found at http://hanford-site.pnl.gov/groundwater. 


\section{Summary}

This report presents the results of a continued groundwater quality assessment to determine the rate of movement and extent of contamination in the uppermost aquifer beneath Waste Management Area S-SX in the 200 West Area of the Hanford Site. The primary focus is on interpretation of data acquired between April 2000 and December 2001 from new and existing wells since the last assessment report (PNNL-13441). In addition to routine quarterly groundwater sampling from the new and existing network wells, additional hydrologic testing was also conducted, adding to the understanding of site-specific hydrologic conditions.

Two upgradient replacement wells and six new downgradient wells were installed. No significant new contamination was discovered in the new wells during the report period. However, rapidly increasing concentrations of technetium-99 and associated mobile tank waste contaminants were observed in two existing S tank farm wells (299-W22-44 and 299-W22-48).

Technetium-99 continues to be the constituent with the highest concentration relative to a drinking water standard. Well 299-W23-19 at tank SX-115 continues to exhibit elevated concentrations with a maximum of $81,500 \mathrm{pCi} / \mathrm{L}$ relative to the drinking water standard of $900 \mathrm{pCi} / \mathrm{L}$. Interim corrective measures (conducted by CH2M HILL Hanford Group, Inc.) included (1) permanently cutting and capping old pressurized water lines in close proximity to the soil column source of contamination near tank SX-115 and (2) surface run-on control. The water line work was completed on April 25, 2001. If suspected water line leakage transported tank waste through the vadose zone to groundwater at this location, contaminant concentrations should begin to decline from the maximum of 81,500 pCi/L that occurred in March 2001. A clear downward trend has not yet been established in this well. However, technetium-99 concentrations have not continued to increase as observed prior to the corrective measures.

Evaluation of the extent of the apparent contaminant plume at the southern end of the SX tank farm suggests the rate of movement is slow ( $<20$ meters per year) and the contaminant plume is limited in extent. Predicted areal distribution is consistent with contaminant concentrations in the observations wells within the boundaries of the theoretical concentration contours, lending confidence in the predictive modeling approach used.

Based on the predicted technetium-99 concentration contours, the areal extent of groundwater contamination that exceeds the cleanup target level of $9,000 \mathrm{pCi} / \mathrm{L}$ is estimated to be equivalent to the area of two single-shell tanks (about $800 \mathrm{~m}^{2}$ ). The very low hydraulic conductivities in the southwestern area of the SX tank farm indicate that movement of contaminants that reach the water table in this area may be severely restricted in lateral movement.

The groundwater quality assessment at Waste Management Area S-SX has evolved from a detection phase to assessment and characterization followed by interim corrective measures. The groundwater sampling and analysis conducted at this site in the future should help determine the efficacy of the corrective measures that were undertaken to reduce or eliminate sources of groundwater contamination within Waste Management Area S-SX. 


\section{Acknowledgments}

The authors wish to thank Dave Myers (CH2M HILL Hanford Group, Inc.) and Frank Spane, Stuart Luttrell, and Ron Smith (Pacific Northwest National Laboratory) for critical review and constructive comments on the manuscript. We are also indebted to Evan Dresel, Bruce Williams, Chris Newbill, and Dave Lanigan (Pacific Northwest National Laboratory) for interpretive graphics. Special thanks are due to Darrell Newcomer and Vince Vermeul (Pacific Northwest National Laboratory) for the hydrologic field testing conducted for this project. 


\section{Contents}

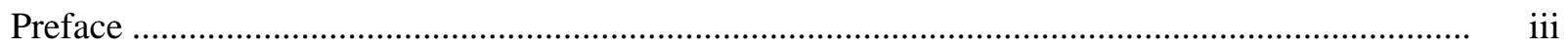

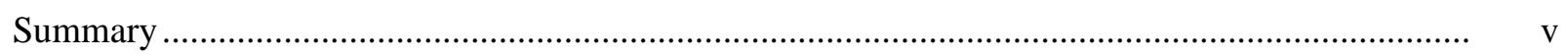

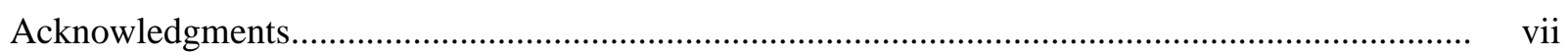

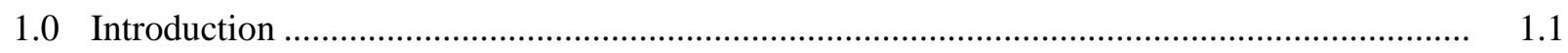

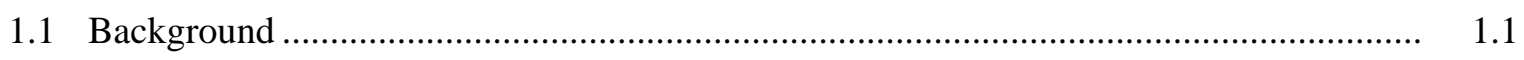

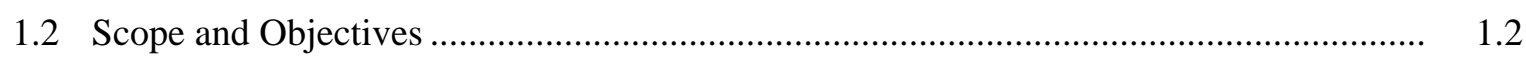

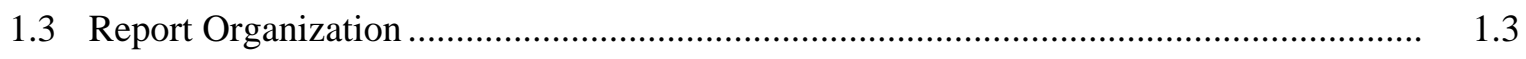

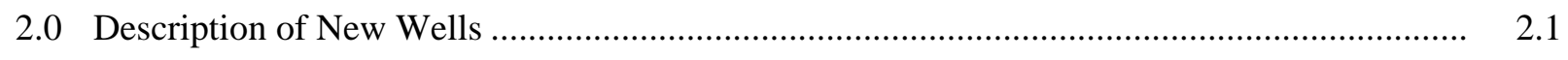

3.0 Rate and Direction of Groundwater Flow .................................................................

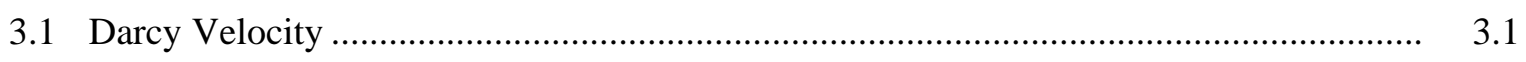

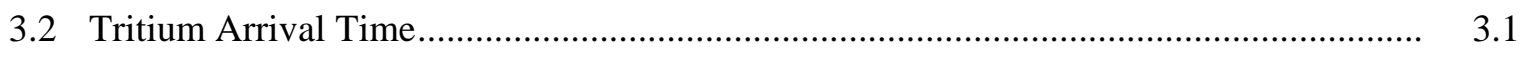

3.3 Large Scale Bromide Tracer Drift Test .................................................................. 3.3

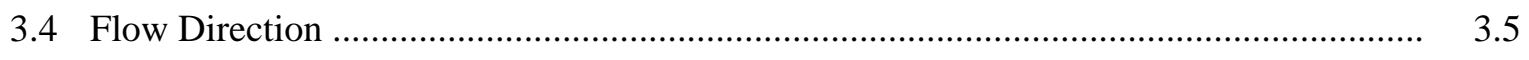

4.0 Maximum Contaminant Concentrations ....................................................................

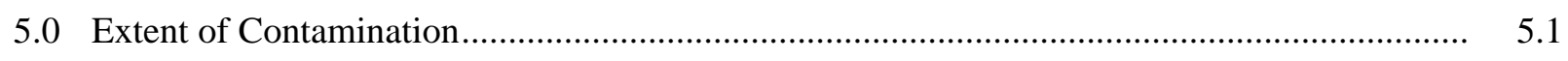

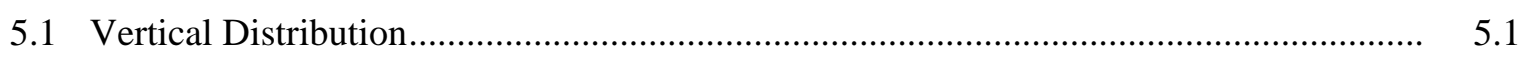

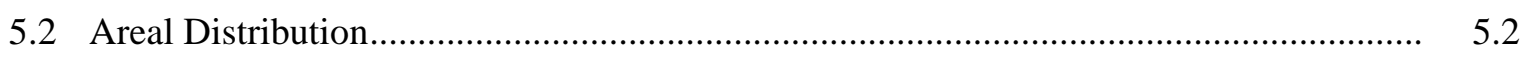

5.2.1 S Tank Farm Area ....................................................................... 5.2

5.2.2 SX Tank Farm Area ........................................................................... 5.5

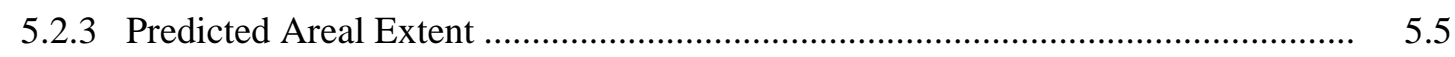

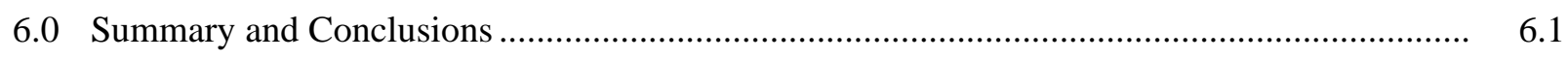

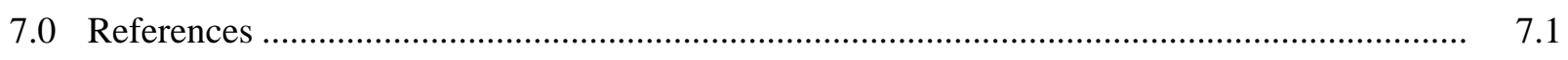

Appendix A - Hydraulic Conductivity Estimates in Waste Management Area S-SX .................... A.1

Appendix B - Hydrologic Testing at Well 299-W23-19: Specific Conductance Results ................ B.1 


\section{Figures}

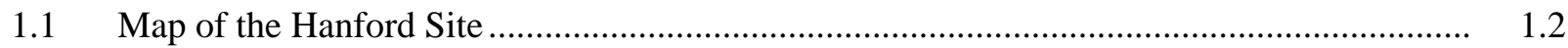

2.1 Location Map of Waste Management Area S-SX Monitoring Wells.................................. 2.3

3.1 Hydraulic Conductivities in New and Existing Wells ................................................ 3.2

3.2 Correlation of Tritium Breakthrough in Upgradient Well 299-W23-9 and Downgradient Wells 299-W22-46, 299-W22-39, and 299-W23-2 .......................................................... 3.3

3.3 2001 Average Tritium Plume and Water-Table Elevation Map for Waste Management Area S-SX and Vicinity .................................................................................................. 3.4

4.1 Technetium-99, Nitrate, and Chromium in Well 299-W22-48 _........................................... 4.3

4.2 Technetium-99, Nitrate, and Chromium in Well 299-W23-19 .......................................... 4.4

4.3 Dissolved Aluminum Concentrations as a Function of $\mathrm{pH}$............................................ 4.5

5.1 Areal Distribution of Technetium-99 at Waste Management Area S-SX ........................... 5.3

5.2 Technetium-99 Concentration in Well 299-W22-44 at S Tank Farm ................................. 5.4

5.3 Technetium-99 Concentration in Well 299-W22-46 at SX Tank Farm ............................. 5.6

5.4a Conceptual Model of Tank Waste Transport through Vadose Zone to Groundwater at

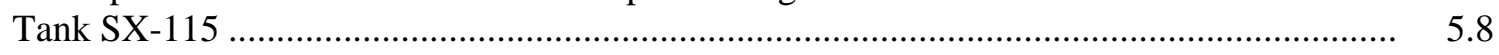

5.4b Location of Water Lines at Southern End of SX Tank Farm .........................................

$5.5 \quad$ Predicted versus Observed Contaminant Arrival Time Response.................................... 5.9

5.6 Predicted Technetium-99 Plume Downgradient from the Source Area Near Tank SX-115 


\section{Tables}

2.1 New Wells Installed at Waste Management Area S-SX in 2000-2001 ............................. 2.2

4.1 Maximum Contaminant Concentrations for Groundwater Samples Collected from Waste Management Area S-SX Network Wells..

5.1 Comparison of Concentrations in Shallow and Deep Wells at Waste Management

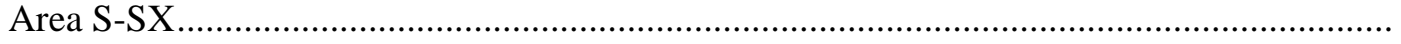

5.2 


\subsection{Introduction}

This report presents the results of a continued groundwater quality assessment to determine the rate and extent of contamination in the uppermost aquifer beneath Waste Management Area S-SX in the 200 West Area of the Hanford Site (Figure 1.1). The primary focus is on interpretation of data acquired between April 2000 and December 2001 from new and existing wells since the last assessment report (Johnson and Chou 2001).

Eight new wells were installed between April 2000 and December 2001:

- Two upgradient replacement wells (299-W23-20 and 299-W23-21) to address past-practice discharge sources (ponds, ditches, and cribs)

- Four downgradient wells (299-W22-80, 299-W22-81, 299-W22-84, 299-W22-85) to enhance spatial coverage, and two downgradient wells (299-W22-82 and 299-W22-83) to further delineate the areal extent of groundwater contamination in the vicinity of the south end of the SX tank farm.

In addition to the routine quarterly groundwater sampling from the new and existing network wells, additional hydrologic testing was conducted, adding to the understanding of site-specific hydrologic conditions. The hydrologic testing is summarized in this report and will be released as a separate document that will include a detailed description of hydrologic test procedures and results.

\subsection{Background}

Waste Management Area S-SX was placed into groundwater quality assessment monitoring status in June 1996. An initial assessment report, based on the results of a first determination, was issued in February 1998 and concluded the waste management area was contributing to groundwater contamination (Johnson and Chou 1998). Thus, a continued assessment of the rate, extent, and concentration profiles of the contamination is required [see 40 CFR 265.93(d)(7)]. Accordingly, an assessment plan (Johnson and Chou 1999a) was prepared to obtain the data needed to determine the rate and extent of contaminant migration and concentrations in groundwater.

The groundwater assessment for Waste Management Area S-SX is being conducted concurrently and in coordination with the vadose zone investigations for the Resource Conservation and Recovery Act (RCRA) Facility Investigation/Corrective Measures Study (RFI/CMS), as described in Tri-Party Agreement Milestone M-45 (Ecology et al. 1998). The RFI/CMS work is being conducted by CH2M HILL Hanford Group, Inc. (Tank Farm Vadose Zone Project) for the Office of River Protection, U.S. Department of Energy, in response to Tri-Party Agreement Milestone M-45. Summary information on assessment results is also included in quarterly reports to the Washington State Department of Ecology (Ecology) and annually in the groundwater monitoring annual reports (http://hanford-site.pnl.gov/ groundwater/reports/gwrep00/start.htm). 


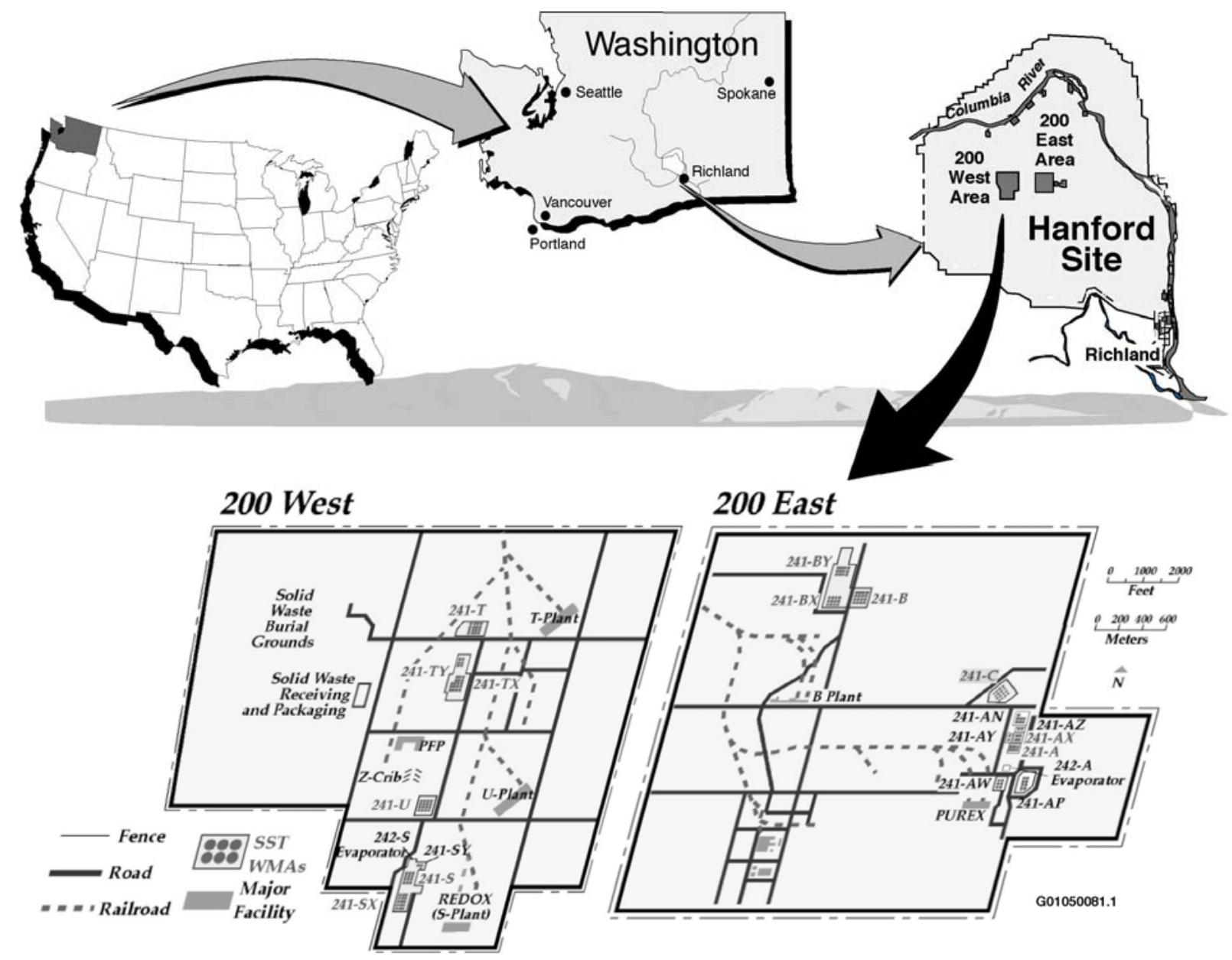

Figure 1.1. Map of the Hanford Site. The single-shell tank storage area addressed in this paper is designated as the 241-S and 241-SX tank farms, located at the southern end of the 200 West Area. SST = Single-shell tanks. WMA = Waste management areas. Rectangles with solid circles show the locations of the nuclear waste storage areas (subsurface tanks and ancillary equipment).

\subsection{Scope and Objectives}

The primary objective of a RCRA groundwater quality assessment is to determine the rate, extent, and concentrations of contaminants attributable to the regulated waste management unit. The scope of this report is limited to new water quality data and hydrologic testing results obtained subsequent to the cutoff (April 2000) for the previous assessment report. Hydrogeology of the site, stratigraphy, waste site descriptions, and contaminant hydrology were described in the first assessment report (Johnson and Chou 1998) and addendum (Johnson and Chou 1999b), and in the updated assessment plan (Johnson and Chou 1999a). 
Supporting information (e.g., drillers log, geologist logs, geophysical logging results) are available in the project files of the Hanford Groundwater Monitoring Project at Pacific Northwest National Laboratory (PNNL) and in the borehole data packages for the new wells that were drilled during the report period (e.g., Horton and Johnson 2001).

\subsection{Report Organization}

Organization of this report is based on the objectives for the continuing assessment, which are to determine the rate and extent of migration and concentration of groundwater contamination. The primary focus is on interpretation of data acquired between April 2000 and December 2001 from new and existing wells since the last assessment report (Johnson and Chou 2001). Accordingly, Chapter 2 provides information on the eight new wells drilled during the report period. Chapter 3 addresses the rate of groundwater movement and direction of flow based on hydrologic data acquired from the existing and new wells tested. Chapter 4 provides the maximum concentrations of the primary mobile constituents of concern at Waste Management Area S-SX that were detected during the report period. Non-RCRA wells are included in addition to the RCRA-compliant wells in the network. Chapter 5 addresses areal and vertical extent of contamination based on existing well data and on new observations from new RCRA-compliant monitoring wells installed for this assessment. Chapter 6 presents conclusions regarding the rate and extent of contaminant migration.

Preliminary analysis results of hydrologic characterization at new wells installed during the report period at Waste Management Area S-SX are included in Appendix A. Results of continuous monitoring of specific conductance during step drawdown and constant discharge testing at well 299-W23-19 inside the SX tank farm are presented in Appendix B. The hydrologic testing in well 299-W23-19 was conducted by CH2M HILL Hanford Group, Inc. to assess the feasibility of a pump and treat at this location.

English units are used in some places in this report (e.g., Tables 2.1, 5.1) to maintain the integrity of the data and because they are used by drillers to measure and report depths and well construction and development details. The conversion to metric may be made by multiplying feet by 0.3048 to obtain meters or multiplying inches by 2.54 to obtain centimeters, and gallons by 3.785 to obtain liters. 


\subsection{Description of New Wells}

The eight new wells drilled during the report period are listed in Table 2.1. Drilling method used, completion depth, drawdown during development, and sediment texture characteristics for the screened interval in the saturated zone are also summarized in Table 2.1. Locations are shown in Figure 2.1.

The two new upgradient wells (299-W23-20 and 299-W23-21) were installed to replace the old upgradient wells (299-W23-13 and 299-W23-14), which were going dry. Four of the new downgradient wells were added to address gaps in spatial coverage as identified in PNNL-13441 (Johnson and Chou 2001). Two mid-field wells (299-W22-82 and 299-W22-83), located near the southeastern corner of SX tank farm, were added to assess the lateral extent of the contaminants believed to be emanating from the southern end of the SX tank farm (see Figure 2.1 for locations).

All of the wells were completed with nominally 11 meters of submerged screen. Two of the wells (one upgradient and one downgradient) were drilled by air rotary methods. The others were all drilled by cable tool methods. Split spoon core sections in 2-ft (0.61 meter) lengths were collected at the top, mid and bottom of the screened intervals. The latter were used to determine particle size distribution and for lithologic examination.

Indications of relative aquifer permeability are evident from the drawdown that occurred during development pumping (see Table 2.1). The maximum observed drawdown in each well ranged from 2 to $29 \mathrm{ft}$ (0.61 to 8.8 meters). The wide range in drawdown is indicative of the heterogeneity of the uppermost aquifer in this area.

Sediment texture (see Table 2.1) is suggestive of vertical variability in permeability over the screened interval in several of the wells. For example, sediments in the upper portions of wells 299-W22-20, -81, $-82,-83$, and -84 are described as silty sandy gravel changing to sandy gravel in the bottom sections (approximately the lower quarter of the screened intervals). The most significant textural change is in the bottom of well 299-W22-80 at the southern end of the SX tank farm. The driller's log notes that "heaving sand" was encountered in the bottom portion of this well (Horton and Johnson 2001). Particle-size data from the three core sections collected during drilling of this well also indicate a dramatic change in lithology near the bottom of the well. For example, the sediments are well sorted (uniform sand size) in the core section for the bottom of the well. In contrast, the upper sections indicate a mixture of sand, silt, and gravel. The well-sorted sand from the bottom section was unconsolidated and difficult to maintain in the core barrel (poor recovery). In contrast, the sediments from the upper sections were tightly packed (consolidated or semi-cemented) and good recovery was obtained. The well-sorted, unconsolidated sands in the bottom section are more permeable than the upper zones.

In addition to the above, discrete depth water samples were collected from the air lifted drill cuttings slurry produced from well 299-W22-80 (Horton and Johnson 2001). Field nitrate measurements indicated that nitrate concentrations were fairly uniform at about $8 \mathrm{mg} / \mathrm{L}$ in the upper three-quarters of the screened

interval and declined to about $4 \mathrm{mg} / \mathrm{L}$ in the heaving sand zone near the bottom. The nitrate concentration 
Table 2.1. New Wells Installed at Waste Management Area S-SX in 2000-2001

\begin{tabular}{|c|c|c|c|c|c|c|c|c|}
\hline Well $^{(\mathrm{a})}$ & $\begin{array}{c}\text { Date } \\
\text { Drilled } \\
\end{array}$ & $\begin{array}{l}\text { Drilling } \\
\text { Method } \\
\end{array}$ & $\begin{array}{l}\text { Submerged } \\
\text { Screen } \\
\text { Length (ft) } \\
\end{array}$ & $\begin{array}{c}\text { Development } \\
\text { Rate/Max. } \\
\text { Drawdown } \\
\text { (gpm/ft) } \\
\end{array}$ & $\begin{array}{c}\text { Pump } \\
\text { Intake } \\
(\mathrm{ft}) \\
\end{array}$ & $\begin{array}{l}\text { Total Drill } \\
\text { Depth } \\
\text { (ft) } \\
\end{array}$ & $\begin{array}{l}\text { Depth to } \\
\text { Water } \\
\text { (ft) }^{(\mathrm{b})} \\
\end{array}$ & Comments \\
\hline W23-20 (c) & $08 / 2000$ & Air Rotary & 34.9 & $29 / 2$ & 220.8 & 260 & 215.6 & $\begin{array}{l}\text { Silty sandy gravel in upper sections of } \\
\text { screened interval and sandy gravel in } \\
\text { bottom }(250 \mathrm{ft})\end{array}$ \\
\hline $\mathrm{W} 23-21^{(\mathrm{c})}$ & $10 / 2000$ & Cable Tool & 37.0 & $6 / 25$ & 223 & 259 & 212.7 & $\begin{array}{l}\text { Silty sandy gravel - no change in } \\
\text { texture for screened interval }\end{array}$ \\
\hline W22-80 & $09 / 2000$ & Air Rotary & 34.8 & $30 / 3$ & 214.5 & 251 & 205.3 & $\begin{array}{l}\text { Major texture break in bottom } 1 / 4 \text { of } \\
\text { screened interval; "heaving” sand at } \\
\text { bottom ( } 241 \mathrm{ft}) \\
\text { Silty-sandy gravel down to heaving } \\
\text { sand zone }\end{array}$ \\
\hline W22-81 ${ }^{(\mathrm{d})}$ & $01 / 2001$ & Cable Tool & 35.8 & $8.5 / 22$ & 237 & 269 & 225.9 & $\begin{array}{l}\text { Silty-sandy-gravel in screened interval } \\
\text { - sandy gravel in bottom section } \\
(260.5 \mathrm{ft})\end{array}$ \\
\hline W22-82 ${ }^{(\mathrm{e})}$ & $02 / 2001$ & Cable Tool & 34.9 & $10 / 18.8$ & 237.4 & 261 & 226.3 & $\begin{array}{l}\text { Silty sandy gravel in top section - } \\
\text { sandy gravel in bottom section }(260 \mathrm{ft})\end{array}$ \\
\hline W22-83 ${ }^{(\mathrm{e})}$ & $03 / 2001$ & Cable Tool & 33.5 & $10 / 29$ & 237 & 261.3 & 227.8 & $\begin{array}{l}\text { Silty sandy gravel in upper sections } \\
\text { and sandy gravel in bottom section } \\
(262 \mathrm{ft})\end{array}$ \\
\hline W22-84 ${ }^{(\mathrm{d})}$ & $10 / 2001$ & Cable Tool & 31.4 & $10 / 17.5$ & 245.4 & 273 & 235.6 & $\begin{array}{l}\text { Silty sandy gravel in upper sections - } \\
\text { sandy gravel in bottom section ( } 265 \mathrm{ft} \text { ) }\end{array}$ \\
\hline W22-85 ${ }^{(\mathrm{d})}$ & $10 / 2001$ & Cable Tool & 33.6 & $30 / 11.5$ & 226.6 & 260 & 218.4 & $\begin{array}{l}\text { Sandy gravel over entire screened } \\
\text { interval }\end{array}$ \\
\hline $\begin{array}{l}\text { (a) All we } \\
\text { (b) At tim } \\
\text { (c) Replac } \\
\text { (d) Enhan } \\
\text { (e) Help d }\end{array}$ & $\begin{array}{l}\text { me prefix } \\
\text { drilling. } \\
\text { int for upg } \\
\text { patial cove } \\
\text { eate contal }\end{array}$ & $\begin{array}{l}\text { by } 299-\text {. } \\
\text { ient well goi } \\
\text { e. }\end{array}$ & & & & & & \\
\hline
\end{tabular}




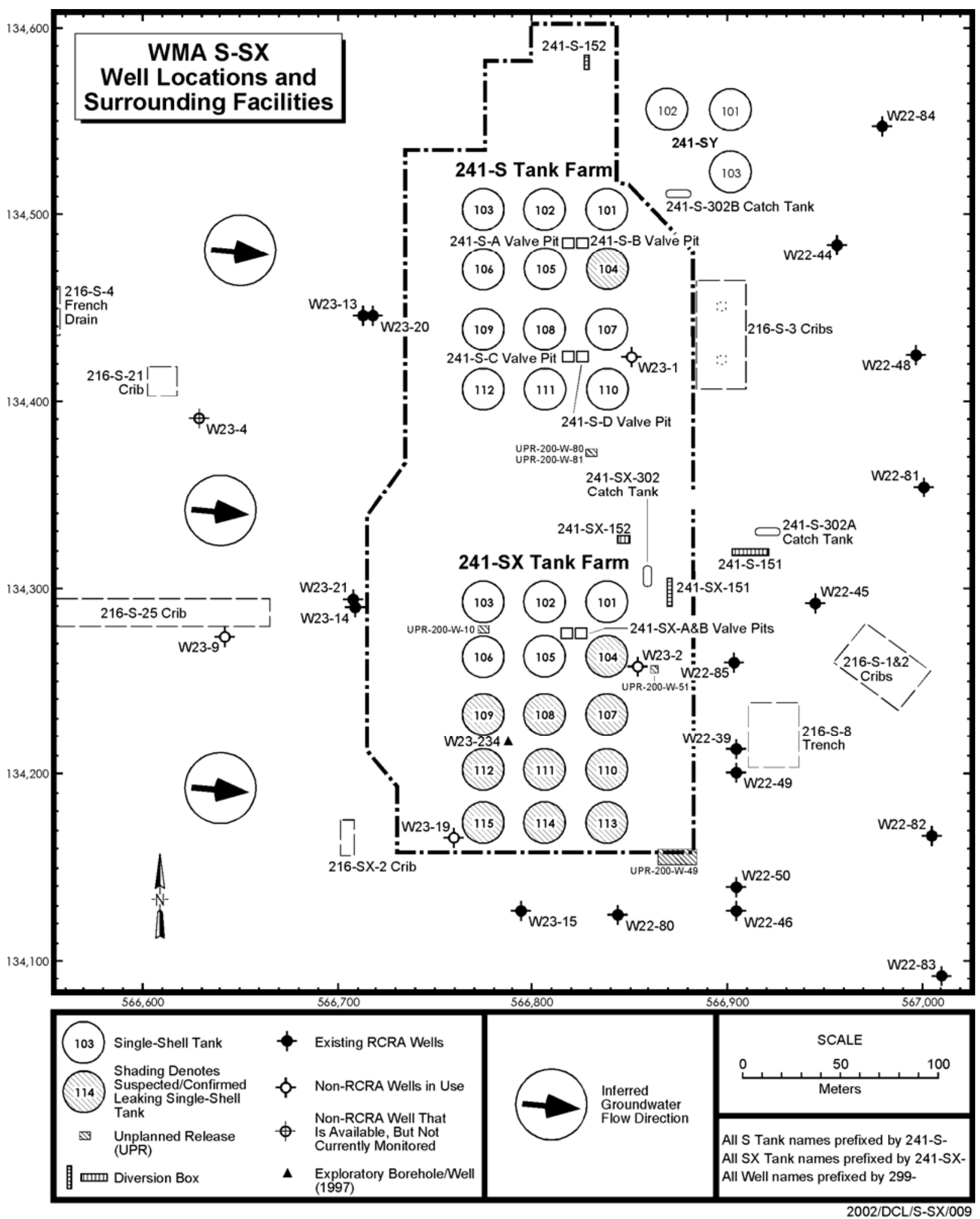

Figure 2.1. Location Map of Waste Management Area S-SX Monitoring Wells 
observed after a pump was installed was $6 \mathrm{mg} / \mathrm{L}$, suggesting that about half of the water produced from the well came from the lower quarter of the screened interval. The heaving sand zone observed at the bottom of this well was apparently not evident in the other wells in the S-SX network, although it has been noted in other wells in the 200 West Area. At S-SX, the heaving sand zone could be present but at depths below the maximum drill depths at the other network well locations (i.e., in wells other than well 299-W22-80).

The above observation suggests a deeper, relatively thin producing zone with low contaminant concentrations can dilute the concentrations from a lower yielding zone with higher contaminant concentrations at the top of the aquifer. The opposite could occur if the deeper, higher yielding zone has high contaminant concentrations relative to the top of the aquifer. The latter effect was observed in a well at the northeast corner of $\mathrm{T}$ farm.

In summary, vertical variability in aquifer properties must be kept in mind when interpreting contaminant concentrations and hydraulic data from wells completed across zones with variable permeability (i.e., in heterogeneous aquifers). 


\subsection{Rate and Direction of Groundwater Flow}

The rate of groundwater movement beneath and in the vicinity of Waste Management Area S-SX is estimated from classical methods (Darcy equation), borehole tracer dilution tests, and observation of contaminant plume movement and tracer drift test arrival times.

\subsection{Darcy Velocity}

The Darcy equation for estimating velocity (v) requires measurement of hydraulic conductivity (K), effective porosity $\left(\mathrm{n}_{\mathrm{e}}\right)$ and hydraulic gradient (i). The velocity is calculated from the following relationship:

$$
\mathrm{v}=\mathrm{Ki} / \mathrm{n}_{\mathrm{e}}
$$

For the Waste Management Area S-SX assessment, new hydraulic conductivity data were obtained from slug tests and drawdown tests conducted in the new wells installed for this site and in selected existing wells. Effective porosity was determined using tracer drift and pumpback test methods as described in PNNL Procedures for Groundwater Investigations ${ }^{1}$ (PNL-MA-567, AT-7) and in Spane et al. (2001).

Variation in hydraulic conductivities among the existing and new wells tested (see Figure 3.1 and Appendix A) is consistent with the known aquifer heterogeneity and low permeability in the study area. The results also suggest the average groundwater velocity should be very low (5 to 20 meters per year) in the study area based on Darcy velocity estimates previously reported (Connelly et al. 1992) and based on more recent hydrologic test results (Spane et al. 2001).

\subsection{Tritium Arrival Time}

High concentrations of tritium occurred in groundwater at the 216-S-25 Crib in the past due to discharges of condensate from the S and SX tank farms. The most recent discharge occurred in 1985 and continued semi-erratically for about 5 years (Figure 3.2). Monitoring well 299-W23-9, located next to the eastern end of the crib (see Figure 2.1 for the 216-S-25 Crib and well locations), showed a sharp upward increase in 1986 in response to the crib discharges. This same sharp upward inflection occurs in three of the downgradient wells (299-W23-2, 299-W22-39, and 299-W22-46) located near the southeastern corner of the SX tank farm (see Figure 3.2). The sharp upward inflection in all of these downgradient wells

\footnotetext{
1 "Recommendations for Conducting Bromide Tracer-Dilution and Drift Pump-Back Tests." Procedure AT-7, found in Procedures for Ground-Water Investigations, PNL-MA-567, Pacific Northwest National Laboratory, Richland, Washington.
} 


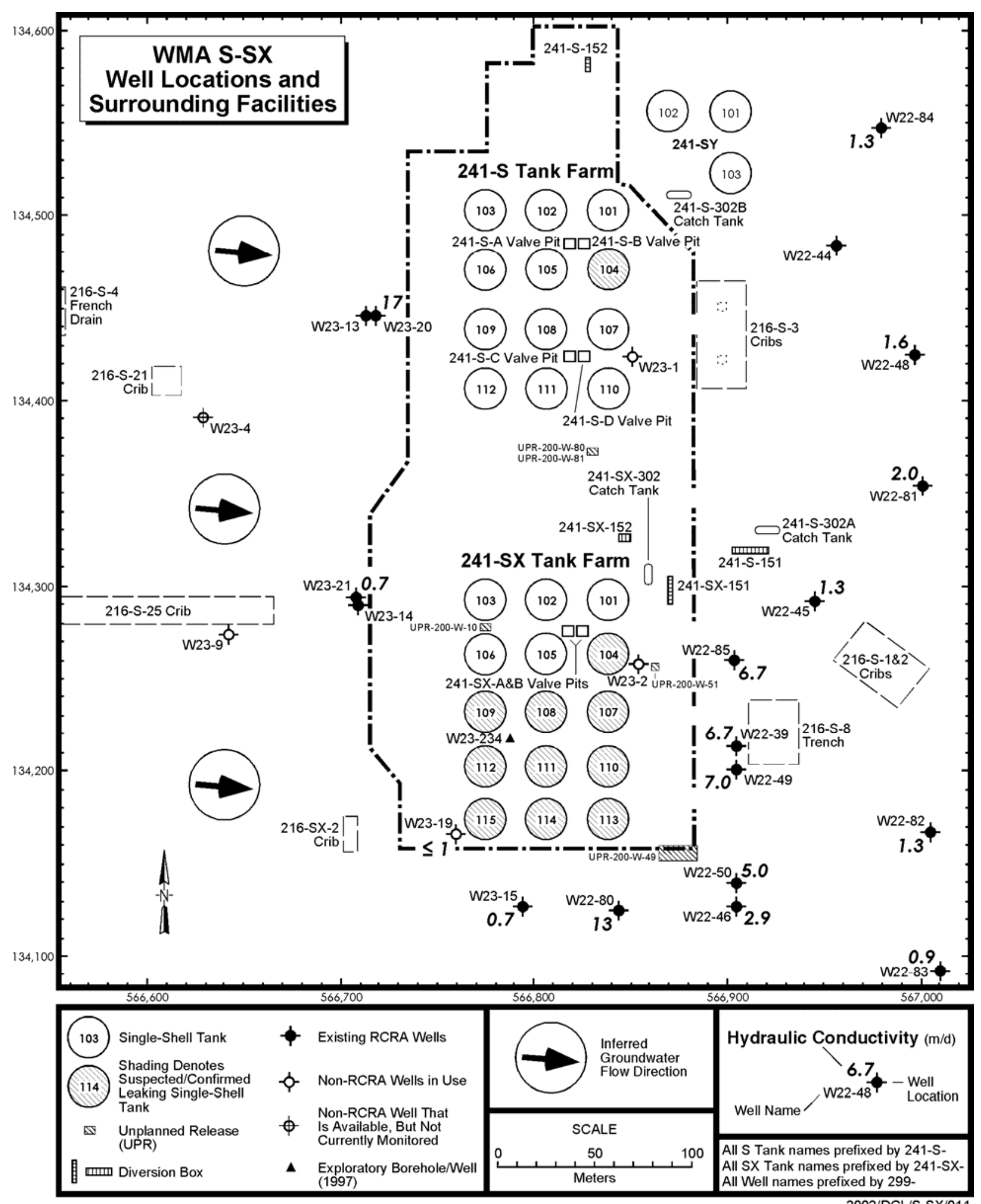

Figure 3.1. Hydraulic Conductivities in New and Existing Wells (1999-2001) 


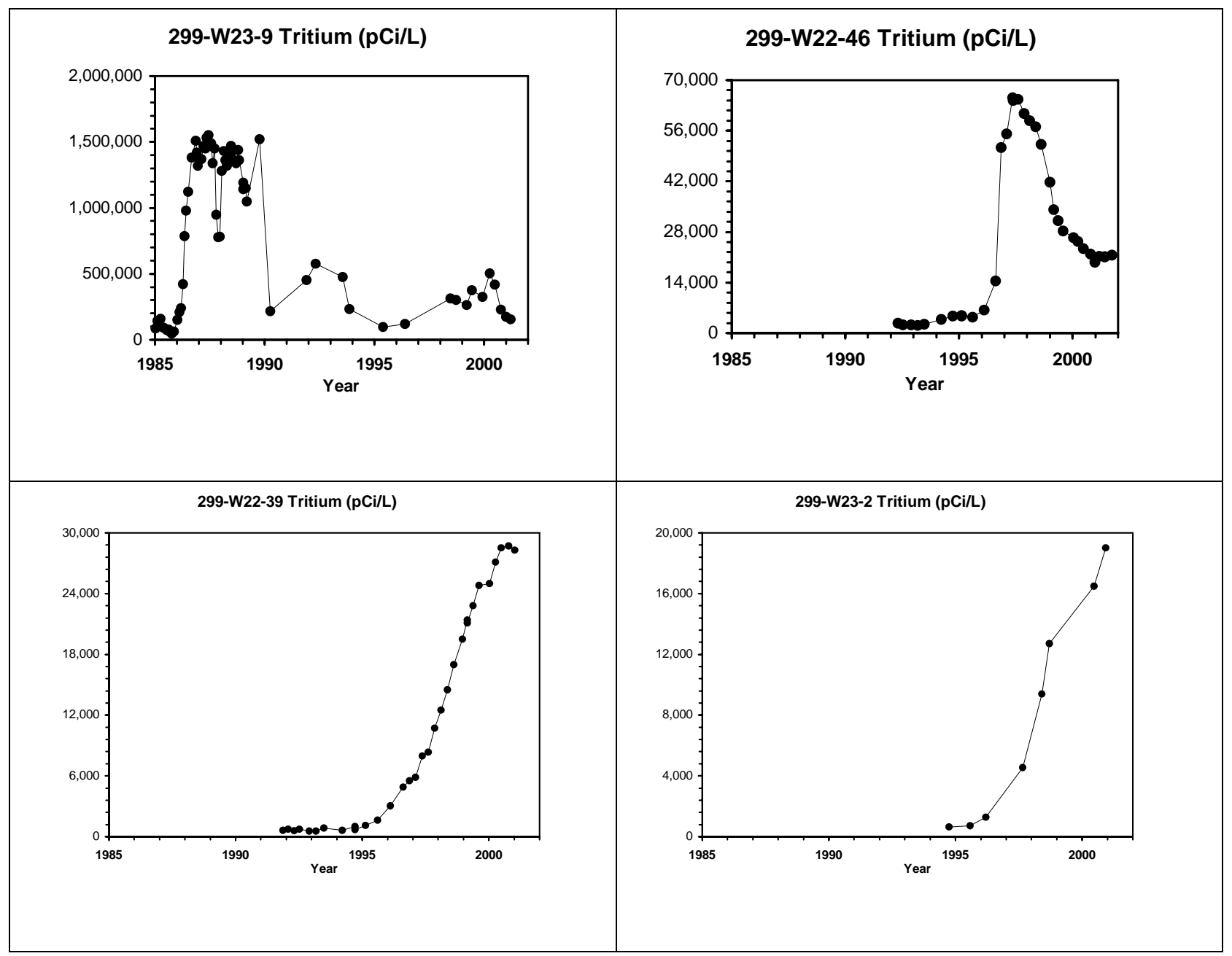

Figure 3.2. Correlation of Tritium Breakthrough in Upgradient Well 299-W23-9 and Downgradient Wells 299-W22-46, 299-W22-39, and 299-W23-2

occurs in about 1996 (plus or minus a year). Assuming the tritium source was the 216-S-25 crib and that well 299-W23-9 reflects the time-concentration pattern for this source in groundwater, the apparent travel time to the downgradient wells noted above is $~ 10$ years (1986 to 1996). The average distance between well 299-W23-9 and these wells is about 250 meters. The apparent flow velocity along the centerline of the plume (Figure 3.3), is then 250 meters per 10 years $=25$ meters per year.

\subsection{Large Scale Bromide Tracer Drift Test}

A volume of 16,000 liters of a 60,000 $\mu \mathrm{g} / \mathrm{L}$ bromide solution (in Columbia River water) was injected into the top of the aquifer beneath the SX tank farm in March 1999, just prior to abandonment of borehole 41-09-39 (now named well 299-W23-234). The tracer was injected into a shallow (1.5 meter) screened interval in an attempt to simulate a large area source that had just entered the aquifer. The total dissolved solids content of the bromide solution matched the ambient groundwater. An initial tracer patch of 


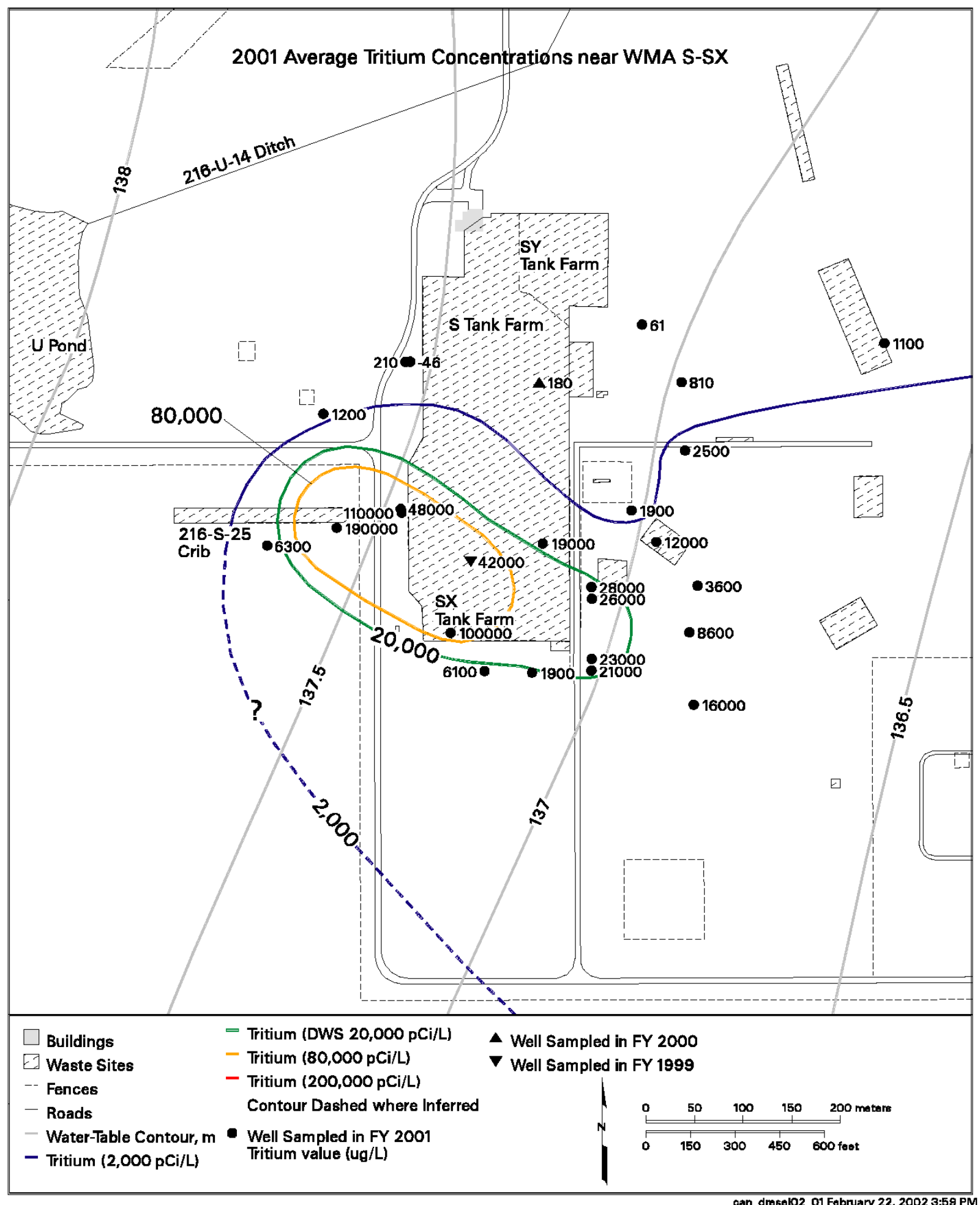

Figure 3.3. 2001 Average Tritium Plume and Water-Table Elevation Map (March 2001) for Waste Management Area S-SX and Vicinity 
20 meters in diameter, or about the diameter of a single-shell tank, was intended. The primary objective was to test the efficiency of the downgradient monitoring wells to detect a simulated leak from a tank source. The elapsed time between when the tracer was injected and when it first appears in downgradient monitoring wells should also indicate flow rate in that area of the waste management area. Bromide measurements in downgradient wells are made by special request on samples collected during the routine RCRA quarterly sampling of the monitoring network wells. Nearly 3 years have passed since injection of the tracer. There is no evidence that the tracer has arrived yet in any of the wells located downgradient from the point of injection (i.e., wells 299-W23-19, 299-W23-15, 299-W22-50, 299-W22-49, 299-W22-46, 299-W22-39, and 299-W22-45). Bromide concentrations in these wells are currently being reported as non-detects with a detection limit of $10 \mu \mathrm{g} / \mathrm{L}$. Since the initial bromide concentration of the tracer patch was $60,000 \mu \mathrm{g} / \mathrm{L}$, bromide should be detectable in downgradient wells even at a dilution of 100 to 1,000 fold. Also, with such a slow apparent flow rate, it should take a year or more for the tracer patch (estimated to be 20 meters in diameter at the source) to pass by. Based on trend surface analysis of flow direction, well 299-W22-49 should be close to the center line of the trajectory (15 degrees south of due east) from the point of injection at well 299-W23-234. Of course in a heterogeneous aquifer, the actual pathway could deviate significantly from a straight line. Nevertheless, some idea of lateral spreading of the tracer patch can be obtained from the continuous release plume case (see Section 5.2.3).

The absence of bromide from the tracer drift test in any downgradient well is consistent with the low computed Darcy velocities (Spane et al. 2001) and the contaminant plume arrival times. For example, the nearest distance to a downgradient well from the point of injection is $~ 100$ meters, and assuming an average velocity 25 meters per year (see Section 3.2), it would take 4 years to arrive at this well. The absence of the tracer in downgradient wells is consistent with the slow travel times indicated above based on tritium arrival times and Darcy velocities.

\subsection{Flow Direction}

The direction of groundwater flow was estimated based on the gradient in the water-table elevations in the S-SX network monitoring wells. This approach assumes the aquifer is homogeneous. Because there is evidence that the aquifer is non-homogeneous, this limitation must be kept in mind when applying the gradient analysis approach to estimate flow direction. A general flow direction may be estimated over the study area, but at any specific location, perturbations may occur in the local flow direction due to localized low permeability zones. Such variability is evident in the distribution of hydraulic conductivities for this waste management area (see Figure 3.1). For example, the southwestern area of the waste management area appears to be in a zone of very low hydraulic conductivity.

Trend surface analysis was applied to the water-table elevation gradient for various combinations of wells in the waste management area network (Spane et al. 2001). Annual water-table elevation measurements from 1992 to the present were selected for the same month of the year (August) to minimize atmospheric disturbance effects (barometric pressure changes can cause fluctuations in the static water level in a well and these effects are at a minimum during the late summer). Three combinations were evaluated: (1) the S tank farm and vicinity; (2) SX tank farm; and (3) the waste management area as a whole. A change in the direction of groundwater flow from southeast to a more easterly direction over time was evident in all three cases evaluated. Most of the shift in flow direction occurred in the northern 
part of the waste management area. This is because until June 1995, wastewater was discharged to the 216-U-14 ditch along the northwestern edge of the waste management area. The ditch caused a localized groundwater mound at that location, causing a southeasterly flow direction beneath the waste management area. Thus, prior to 1995 the prevailing direction of groundwater flow was more southeasterly. At the present time, the trend surface results for all the network wells combined suggests groundwater is flowing in nearly a due east direction.

The larger scale water-table map of Waste Management Area S-SX (see Figure 3.3) and the surrounding area suggests a flow direction that is a little more east-southeast than indicated by the localized trend surface analysis for Waste Management Area S-SX. The apparent tritium plume superimposed on the water-table map also seems consistent with the flow direction suggested by the larger scale water-table map. The difference in the trend surface results based on a relatively close grouping of network wells (Waste Management Area S-SX network) versus the larger area water-table map may be one manifestation of the effect of a non-homogeneous aquifer. 


\subsection{Maximum Contaminant Concentrations}

Table 4.1 shows the maximum concentrations of the primary mobile constituents of concern at Waste Management Area S-SX detected during the report period. Non-RCRA wells are included as well as the RCRA-compliant wells in the network. Only filtered $(0.4 \mu \mathrm{m})$ metal results were included in the summary. Results for anions and radionuclides are all based on unfiltered samples. The last column shows the highest maximum contaminant concentration (values in bold type) for each constituent divided by the applicable maximum contaminant level or drinking water standard, referred to as the relative hazard index for purposes of this report. The maximum uranium concentration is less than the maximum contaminant level of $30 \mu \mathrm{g} / \mathrm{L}$ and concentrations are higher in the upgradient wells than in down gradient wells (see Table 4.1).

Tritium is widespread in the network wells (see Table 4.1 and Figure 3.2) with the maximum concentration (417,000 pCi/L) occurring in well 299-W23-9 at the 216-S-25 crib. A persistent tritium plume has been associated with this crib for some time. The slow rate of movement is consistent with the low permeability of the aquifer sediments in this area as indicated in Chapter 3. While tritium also is associated with tank waste, the past-practice crib sources obscure additional contributions from tank farm sources, at least in the southern half of the waste management area. In contrast, tritium is virtually absent (see Table 4.1) in the northern half of the waste management area. Thus, any tank farm contribution should be evident in the $S$ tank farm downgradient monitoring wells. Detectable tritium (maximum of 1,460 pCi/L, Table 4.1) was detected in just one well (299-W22-48) in the S tank farm area. This well is also currently showing an increasing trend in technetium-99, chromium, and nitrate (Figure 4.1).

The technetium-99 to nitrate ratios (Johnson and Chou 2001) are about the same ( 0.05 pCi/1g-NO3) in 299-W22-48 as observed in the older well (299-W23-1) located 110 meters directly upgradient and inside the $\mathrm{S}$ tank farm. A transient in technetium-99 concentration that lasted for about one year occurred in well 299-W23-1 in 1986. The maximum concentration observed was 8,250 pCi/L (June 1986). Assuming this transient is just now arriving at well 299-W22-48 (see Figure 4.1), the implied travel time between the two wells is 14 years or $110 \mathrm{~m} / 14$ years $=8 \mathrm{~m} /$ year. An aquifer flow velocity of about 5 meters per year was determined based on tracer-pump back tests conducted in well 299-W22-48 (Spane et al. 2001). If the above assumptions are correct, the technetium-99 concentrations in well 299-W22-48 should reach a maximum and decline rapidly in 2002. If so, the apparent flow velocity in the $\mathrm{S}$ tank farm area, at least in the vicinity of wells 299-W23-1 and 299-W22-48, must be even slower than previously thought. The above considerations also rule out the 216-S-3 crib as a source of the increasing technetium-99 in 299-W22-48 since adequate technetium-99 concentrations occurred in groundwater upgradient of both the crib and well 299-W22-48.

The highest concentrations for all mobile tank waste related constituents of concern (technetium-99, nitrate, chromium, and tritium) occur in well 299-W23-19 located immediately adjacent to tank SX-115. The well with the second highest concentrations of technetium-99, nitrate, and chromium (well 299W-22-46) occurs directly downgradient from tank SX-115. Well 299-W22-48 (downgradient from $\mathrm{S}$ tank farm) is a close third. Contaminant concentrations in the latter well have been rising rapidly over 
Table 4.1. Maximum Contaminant Concentrations for Groundwater Samples Collected from Waste Management Area S-SX Network Wells (April 2000 to December 2001)

\begin{tabular}{|c|c|c|c|c|c|c|c|c|c|c|}
\hline "Analyte & בMCL & W22-39 & W22-44 & W22-45 & W22-46 & W22-48 & W22-49 & W22-50 & W22-80 & W22-81 \\
\hline Chromium $^{(a)}(\mu \mathrm{g} / \mathrm{L})$ & 100 & 16.3 & 5.1 & 27.8 & 39 & 37.3 & 9.3 & 20 & 4.4 & 10.4 \\
\hline${ }^{99} \mathrm{Tc}(\mathrm{pCi} / \mathrm{L})$ & 900 & 115 & 141 & $1,470^{(\mathrm{b})}$ & $4,550^{(\mathrm{b})}$ & $4,050^{(\mathrm{b})}$ & 381 & $3,530^{(\mathrm{b})}$ & $6.4 \mathrm{U}$ & 529 \\
\hline $\begin{array}{l}\text { Nitrate }\left(\text { as } \mathrm{NO}_{3}\right) \\
(\mu \mathrm{g} / \mathrm{L})\end{array}$ & 45,000 & 21,200 & 35,900 & $46,000^{(b)}$ & $48,300^{(\mathrm{b})}$ & $72,200^{(\mathrm{b})}$ & 18,100 & 30,500 & 7,530 & 22,600 \\
\hline Uranium $(\mu \mathrm{g} / \mathrm{L})$ & 30 & 4.64 & 6.32 & 8.43 & 5.82 & 4.56 & 5.65 & 4.82 & 3.54 & 4.95 \\
\hline Gross alpha (pCi/L) & 15 & 3.26 & 4.08 & 5.77 & 6.26 & 3.88 & 2.68 & 4.21 & $\overline{---}$ & --- \\
\hline Gross beta (pCi/L) & 50 & 38.1 & 39.4 & $689^{(\mathrm{b})}$ & $1,780^{(\mathrm{b})}$ & $954^{(\mathrm{b})}$ & 33.2 & $1,340^{(\mathrm{b})}$ & --- & --- \\
\hline Tritium (pCi/L) & 20,000 & $28,700^{(\mathrm{b})}$ & $74.4 \mathrm{U}$ & 2,800 & $23,400^{(\mathrm{b})}$ & 1,460 & $27,400^{(\mathrm{b})}$ & $24,800^{(\mathrm{b})}$ & 1,970 & 3,110 \\
\hline${ }^{90} \mathrm{Sr}(\mathrm{pCi} / \mathrm{L})$ & 8 & $0.42 \mathrm{U}$ & $0.06 \mathrm{U}$ & $0.64 \mathrm{U}$ & $0.73 \mathrm{U}$ & $0.09 \mathrm{U}$ & $0.05 \mathrm{U}$ & 1.49 & --- & --- \\
\hline${ }^{129} \mathrm{I}(\mathrm{pCi} / \mathrm{L})$ & 1 & -- & --- & --- & $0.22 \mathrm{U}$ & $0 \mathrm{U}$ & --- & $0.312 \mathrm{U}$ & --- & -- \\
\hline${ }^{137} \mathrm{Cs}(\mathrm{pCi} / \mathrm{L})$ & 200 & $1.73 \mathrm{U}$ & $0 \mathrm{U}$ & $1.38 \mathrm{U}$ & $0 \mathrm{U}$ & $0.669 \mathrm{U}$ & $0.641 \mathrm{U}$ & $0 \mathrm{U}$ & --- & --- \\
\hline $\operatorname{Iron}^{(a)}(\mu \mathrm{g} / \mathrm{L})$ & 300 & 118 & 30.5 & 30.4 & 37.2 & 34.2 & $347^{(\mathrm{b})}$ & $56.6 \mathrm{U}$ & 35.3 & $31.5 \mathrm{U}$ \\
\hline Manganese $^{(\mathrm{a})}(\mu \mathrm{g} / \mathrm{L})$ & 50 & 7.7 & 0.85 & 0.7 & 0.76 & $120^{(\mathrm{b})}$ & 13.8 & 24.6 & 2.8 & 24.1 \\
\hline Fluoride $(\mu \mathrm{g} / \mathrm{L})$ & 4,000 & 470 & 360 & 470 & 500 & 440 & 520 & 520 & 530 & 440 \\
\hline Aluminum $^{(\mathrm{a})}(\mu \mathrm{g} / \mathrm{L})$ & 50 & $\begin{array}{c}\text { Not } \\
\text { detected }\end{array}$ & $\begin{array}{c}\text { Not } \\
\text { detected }\end{array}$ & 12.5 & $\begin{array}{c}\text { Not } \\
\text { detected }\end{array}$ & 28.3 & $\begin{array}{c}\text { Not } \\
\text { detected }\end{array}$ & $\begin{array}{c}\text { Not } \\
\text { detected }\end{array}$ & 29.7 & 25.1 \\
\hline $\mathrm{pH}$ & {$[6.5,8.5]$} & $\begin{array}{c}6.99, \\
8.29\end{array}$ & $\begin{array}{l}{[7.39,} \\
8.98]\end{array}$ & $\begin{array}{c}8.08, \\
8.43\end{array}$ & $\begin{array}{l}7.80, \\
7.89]\end{array}$ & $\begin{array}{l}8.22, \\
8.81]\end{array}$ & $\begin{array}{l}{[8.46,} \\
8.92]\end{array}$ & $\begin{array}{l}7.90, \\
8.14]\end{array}$ & $\begin{array}{c}7.86, \\
7.9]\end{array}$ & $\begin{array}{l}77.7 \\
7.87]\end{array}$ \\
\hline
\end{tabular}

\begin{tabular}{|c|c|c|c|c|c|c|c|c|c|}
\hline Analyte & W22-82 & W22-83 & W22-84 & W22-85 & W23-1 & W23-2 & W23-4 ${ }^{(\mathrm{c})}$ & W23-9 ${ }^{\text {(c) }}$ & W23-13 $3^{(\mathrm{c})}$ \\
\hline Chromium $^{(\mathrm{a})}(\mu \mathrm{g} / \mathrm{L})$ & 4.1 & 3.5 & 10 & $30 \mathrm{U}$ & 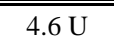 & 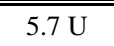 & $7.5 \mathrm{U}$ & 8 & 30.6 \\
\hline${ }^{99} \mathrm{Tc}(\mathrm{pCi} / \mathrm{L})$ & 62.7 & 483 & $85 \mathrm{U}$ & $70 \mathrm{U}$ & 371 & 131 & 13.6 & 71.4 & $0 \mathrm{U}$ \\
\hline Nitrate $\left(\right.$ as $\left.\mathrm{NO}_{3}\right)(\mu \mathrm{g} / \mathrm{L})$ & 9,300 & 11,500 & 6,200 & 7,085 & 20,400 & 23,900 & 6,640 & $95,200^{(\mathrm{b})}$ & 10,600 \\
\hline Uranium $(\mu \mathrm{g} / \mathrm{L})$ & 1.17 & 1.31 & 1.3 & 0.3 & 5.77 & 6.35 & 25.3 & 19.5 & 16.9 \\
\hline Gross alpha (pCi/L) & --- & --- & --- & --- & $1.74 \mathrm{U}$ & 4.97 & $17.9^{(\mathrm{b})}$ & 12 & 11.3 \\
\hline Gross beta (pCi/L) & --- & --- & --- & --- & $110^{(\mathrm{b})}$ & $56.6^{(\mathrm{b})}$ & 16.2 & 27.5 & 11.8 \\
\hline Tritium (pCi/L) & 10,800 & 16,900 & & & $176 \mathrm{U}$ & 19,000 & 1,480 & $417,000^{(b)}$ & $152 \mathrm{U}$ \\
\hline${ }^{90} \mathrm{Sr}(\mathrm{pCi} / \mathrm{L})$ & --- & --- & --- & --- & $0.54 \mathrm{U}$ & $0.18 \mathrm{U}$ & $0.16 \mathrm{U}$ & --- & $0.13 \mathrm{U}$ \\
\hline${ }^{129} \mathrm{I}(\mathrm{pCi} / \mathrm{L})$ & --- & --- & --- & --- & $0 \mathrm{U}$ & $0.073 \mathrm{U}$ & --- & $0.148 \mathrm{U}$ & --- \\
\hline${ }^{137} \mathrm{Cs}(\mathrm{pCi} / \mathrm{L})$ & --- & --- & --- & --- & $4.96 \mathrm{U}$ & $1.39 \mathrm{U}$ & $0.253 \mathrm{U}$ & $0 \mathrm{U}$ & $0.341 \mathrm{U}$ \\
\hline $\operatorname{Iron}^{(a)}(\mu \mathrm{g} / \mathrm{L})$ & 40.1 & 27.7 & $320^{(\mathrm{b})}$ & $30 \mathrm{U}$ & 23 & 94.7 & $56.6 \mathrm{U}$ & $34.9 \mathrm{U}$ & 176 \\
\hline Manganese $^{(\mathrm{a})}(\mu \mathrm{g} / \mathrm{L})$ & $113^{(\mathrm{b})}$ & $72.6^{(\mathrm{b})}$ & $51^{(\mathrm{b})}$ & $53^{(\mathrm{b})}$ & $109^{(\mathrm{b})}$ & 9.1 & $2.9 \mathrm{U}$ & 12.3 & 14.4 \\
\hline Fluoride $(\mu \mathrm{g} / \mathrm{L})$ & 570 & 530 & 1,300 & 1,500 & 440 & 420 & 380 & 390 & 410 \\
\hline Aluminum $^{(\mathrm{a})}(\mu \mathrm{g} / \mathrm{L})$ & 43.8 & 20.8 & $\begin{array}{c}\text { Not } \\
\text { detected }\end{array}$ & $\begin{array}{c}\text { Not } \\
\text { detected }\end{array}$ & $\begin{array}{c}\text { Not } \\
\text { detected }\end{array}$ & $\begin{array}{c}\text { Not } \\
\text { detected }\end{array}$ & $\begin{array}{c}\text { Not } \\
\text { detected }\end{array}$ & $\begin{array}{c}\text { Not } \\
\text { detected }\end{array}$ & $\begin{array}{c}\text { Not } \\
\text { detected }\end{array}$ \\
\hline $\mathrm{pH}$ & $\begin{array}{l}\text { [7.71, } \\
7.85]\end{array}$ & $\begin{array}{l}{[7.81,} \\
7.91]\end{array}$ & 7.8 & 7.7 & 7.22 & 8.2 & $\begin{array}{l}\text { [7.93, } \\
8.09]\end{array}$ & $\begin{array}{l}\text { [7.73, } \\
8.29]\end{array}$ & $\begin{array}{l}{[8.09,} \\
8.31]\end{array}$ \\
\hline \multicolumn{10}{|c|}{$\begin{array}{l}\text { Note: All well numbers prefixed by 299-. U denotes analytical result is not detected. --- indicates not analyzed. Bold indicates well with } \\
\text { maximum. } \\
\text { (a) Filtered sample results. } \\
\text { (b) Exceeds MCL. } \\
\text { (c) Upgradient wells. } \\
\text { (d) Maximum across all network wells. }\end{array}$} \\
\hline
\end{tabular}


Table 4.1. (contd)

\begin{tabular}{|c|c|c|c|c|c|c|c|c|}
\hline Analyte & $\overline{\mathrm{MCL}}$ & W23-14 ${ }^{(\mathrm{c})}$ & W23-15 & W23-19 & W23-20 (c) & W23-21 $1^{\text {(c) }}$ & $\operatorname{Max}^{(\mathrm{d})}$ & Max/MCL \\
\hline Chromium $^{(\mathrm{a})}(\mu \mathrm{g} / \mathrm{L})$ & 100 & 8.1 & 8.7 & $138^{(\mathrm{b})}$ & 3.1 & 3.8 & 138 & 1.4 \\
\hline${ }^{99} \mathrm{Tc}(\mathrm{pCi} / \mathrm{L})$ & 900 & 36.9 & 21.4 & $81,500^{(b)}$ & 13.2 & 39.7 & 81,500 & 90.6 \\
\hline Nitrate $\left(\right.$ as $\left.\mathrm{NO}_{3}\right)(\mu \mathrm{g} / \mathrm{L})$ & 45,000 & $68,600^{(\mathrm{b})}$ & 12,800 & $677,000^{(\mathrm{b})}$ & 4,870 & $54,400^{(\mathrm{b})}$ & 677,000 & 15.0 \\
\hline Uranium $(\mu \mathrm{g} / \mathrm{L})$ & 30 & 18 & 13.8 & 25.8 & 5.83 & 14.2 & 25.8 & 0.9 \\
\hline Gross alpha (pCi/L) & 15 & 10.3 & 9.16 & $16.1^{(\mathrm{b})}$ & --- & --- & 17.9 & NA \\
\hline Gross beta $(\mathrm{pCi} / \mathrm{L})$ & 50 & 22 & 13.8 & $\mathbf{2 8 , 7 0 0 ^ { ( \mathrm { b } ) }}$ & --- & --- & 28,700 & NA \\
\hline Tritium (pCi/L) & 20,000 & $113,000^{(\mathrm{b})}$ & 8,530 & $115,000^{(\mathrm{b})}$ & $134 \mathrm{U}$ & $49,000^{(\mathrm{b})}$ & 417,000 & 20.8 \\
\hline${ }^{90} \mathrm{Sr}(\mathrm{pCi} / \mathrm{L})$ & 8 & $0.10 \mathrm{U}$ & $0.15 \mathrm{U}$ & $15.1 \mathrm{U}$ & -- & -- & 1.49 & 0.19 \\
\hline${ }^{129} \mathrm{I}(\mathrm{pCi} / \mathrm{L})$ & 1 & --- & --- & $5.64^{(\mathrm{b})}$ & --- & --- & 5.64 & 5.6 \\
\hline${ }^{137} \mathrm{Cs}(\mathrm{pCi} / \mathrm{L})$ & 200 & $0 \mathrm{U}$ & $2.06 \mathrm{U}$ & $2.56 \mathrm{U}$ & $\begin{array}{c}-- \\
\end{array}$ & $\begin{array}{l}-- \\
\end{array}$ & $\begin{array}{c}\text { Not } \\
\text { detected }\end{array}$ & NA \\
\hline $\operatorname{Iron}^{(a)}(\mu \mathrm{g} / \mathrm{L})$ & 300 & $2,530^{(\mathrm{b})}$ & 248 & 102 & 16 & 40.5 & 2,530 & 8.4 \\
\hline Manganese $^{(\mathrm{a})}(\mu \mathrm{g} / \mathrm{L})$ & 50 & $202^{(\mathrm{b})}$ & 2.2 & $329^{(b)}$ & 2.2 & 16.9 & 329 & 6.6 \\
\hline Fluoride $(\mu \mathrm{g} / \mathrm{L})$ & 4,000 & 320 & 500 & 330 & 480 & 460 & 1,500 & 0.4 \\
\hline Aluminum $^{(\mathrm{a})}(\mu \mathrm{g} / \mathrm{L})$ & 50 & $1,160^{(\mathrm{b})}$ & 21.2 & 24.7 & 25.6 & 44.3 & 1,160 & 23.2 \\
\hline $\mathrm{pH}$ & {$[6.5,8.5]$} & $\begin{array}{c}{[8.16,} \\
8.28]\end{array}$ & $\begin{array}{l}7.89, \\
8.11]\end{array}$ & {$[7.5,7.84]$} & $\begin{array}{c}{[7.96,} \\
8.05]\end{array}$ & $\begin{array}{l}7.71, \\
7.91]\end{array}$ & $\begin{array}{c}6.99, \\
8.98]\end{array}$ & NA \\
\hline \multicolumn{9}{|c|}{$\begin{array}{l}\text { Note: All well numbers prefixed by 299-. U denotes analytical result is not detected. --- indicates not analyzed. Bold indicates well with } \\
\text { maximum. } \\
\text { (a) Filtered sample results. } \\
\text { (b) Exceeds MCL. } \\
\text { (c) Upgradient wells. } \\
\text { (d) Maximum across all network wells. }\end{array}$} \\
\hline
\end{tabular}

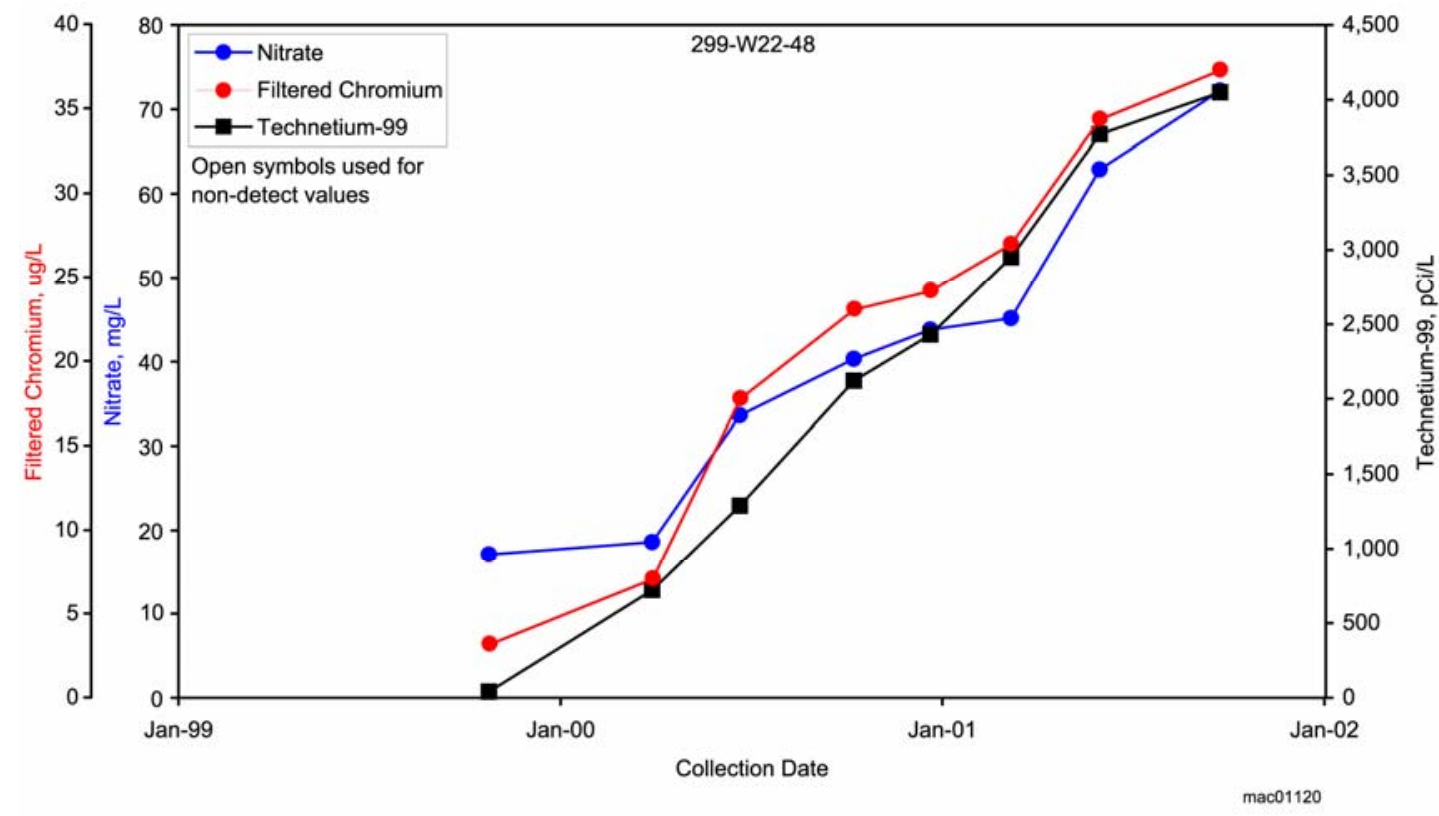

Figure 4.1. Technetium-99, Nitrate, and Chromium in Well 299-W22-48 
the last year or so. Trends for the major mobile constituents related to tank waste are similar in both this well (see Figure 4.1) and well 299-W23-19 (Figure 4.2), indicative of a tank waste source in the S and SX tank farm areas, respectively.

The abrupt decline from the maximum that occurred in March 2001 for well 299-W23-19 may be related to pumping rate during purging prior to sampling (see Appendix B). For example, during a 3-hour development/step drawdown test at this well, continuous electrical conductivity monitoring of the discharge water was conducted. The electrical conductivity was observed to increase from a low of $800 \mu \mathrm{S} / \mathrm{cm}$ to a high of nearly $1,600 \mu \mathrm{S} / \mathrm{cm}$ as the pumping rate was decreased from 5 gallons per minute to about 1 gallon per minute. Nitrate and technetium-99 are approximately proportional to electrical conductivity in this well. Thus, contaminant concentrations ranged approximately a factor of two as a result of the altered pumping rate. When the pumping rate was held constant for a 72-hour period at a rate of 3 gallons per minute, the conductivity remained within a narrow range of 1,250 to $1,300 \mu \mathrm{S} / \mathrm{cm}$ (see Appendix B). Routine sampling of this well typically is conducted with a nominal purge rate of 1 gallon per minute. However, for the sampling event that resulted in the sharp drop in contaminant concentrations (August 2001; see Figure 4.2), the purge rate was initially set at 3 gallons per minute. The lower contaminant concentrations may have been due to the higher than normal purge rate rather than due to an actual change in contaminant concentrations in the aquifer.

Other apparent exceedances (see Table 4.1) are for aluminum, iron, and manganese. The elevated concentrations of these constituents are often associated with high turbidity. Apparently breakthrough of fine particulates (colloidal) through the membrane filter must occur when particle loading is high.

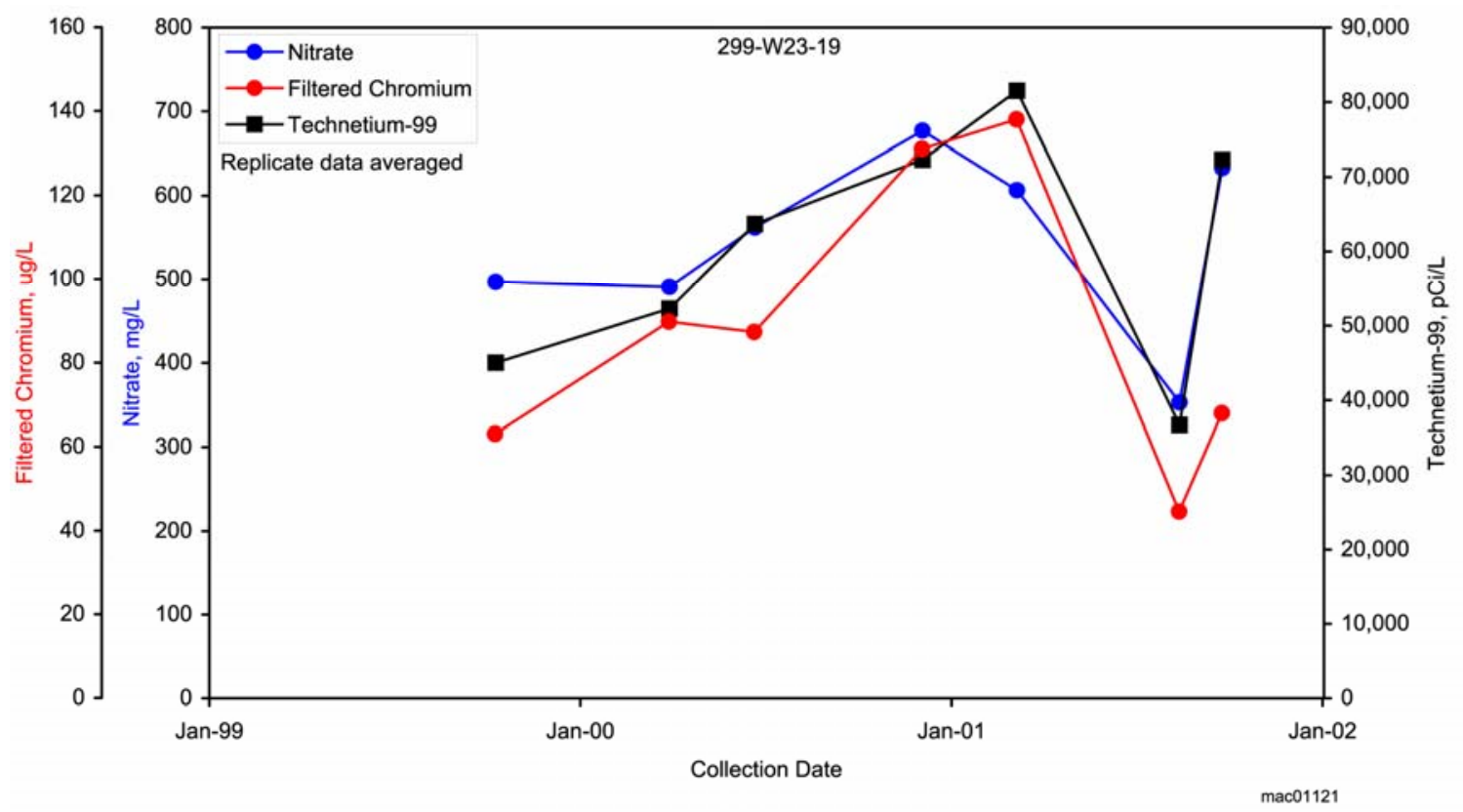

Figure 4.2. Technetium-99, Nitrate, and Chromium in Well 299-W23-19 
Aluminum is abundant in contained tank waste but is not expected to be very soluble at the natural $\mathrm{pH}$ of groundwater. For example, based on $\mathrm{pH}$-aluminum solubility calculations (Figure 4.3), the theoretical dissolved aluminum concentration (zones below the line separating the solid phase, gibbsite, from dissolved species) is about $27 \mu \mathrm{g} / \mathrm{L}$ at a typical groundwater $\mathrm{pH}$ of 8 . Thus it is unlikely that dissolved aluminum could exist at concentrations approaching the MCL (50 $\mu \mathrm{g} / \mathrm{L})$ even if elevated concentrations in pore fluid reached groundwater

Figure 4.3 also shows that aluminum is soluble at a $\mathrm{pH}$ that is either very high or very low. Therefore, tank waste that leaked into the soil column at very high $\mathrm{pH}$ ( 12 or greater) would contain mobile species of aluminum. Some concern has been expressed that soluble aluminum in tank waste could reach groundwater. However, once the excess hydroxide is neutralized by reaction with aluminosilicate mineral phases, the $\mathrm{pH}$ will drop to $\sim 9$ and the dissolved aluminum should precipitate as a solid phase. By the time additional dilution of pore fluid occurs in transit to the water table, and after reaching the saturated zone at the water table, the natural groundwater $\mathrm{pH}$ of around 8 should dominate the $\mathrm{pH}$ of any waste liquid mixtures in groundwater. Except for two wells (299-W22-48 and 299-W22-49) that have somewhat elevated $\mathrm{pH}$ (attributed to residual cement that seeped into the sand pack around the screen), all network wells have a $\mathrm{pH}$ of around 8 (see Table 4.1).

The high maximum concentrations (filtered) of iron (up to 2,500 $\mu \mathrm{g} / \mathrm{L}$ ), manganese (202 $\mu \mathrm{g} / \mathrm{L}$ ), and aluminum (1,160 $\mu \mathrm{g} / \mathrm{L})$ occurred in well 299-W23-14 during a sampling event (December 29, 2000)

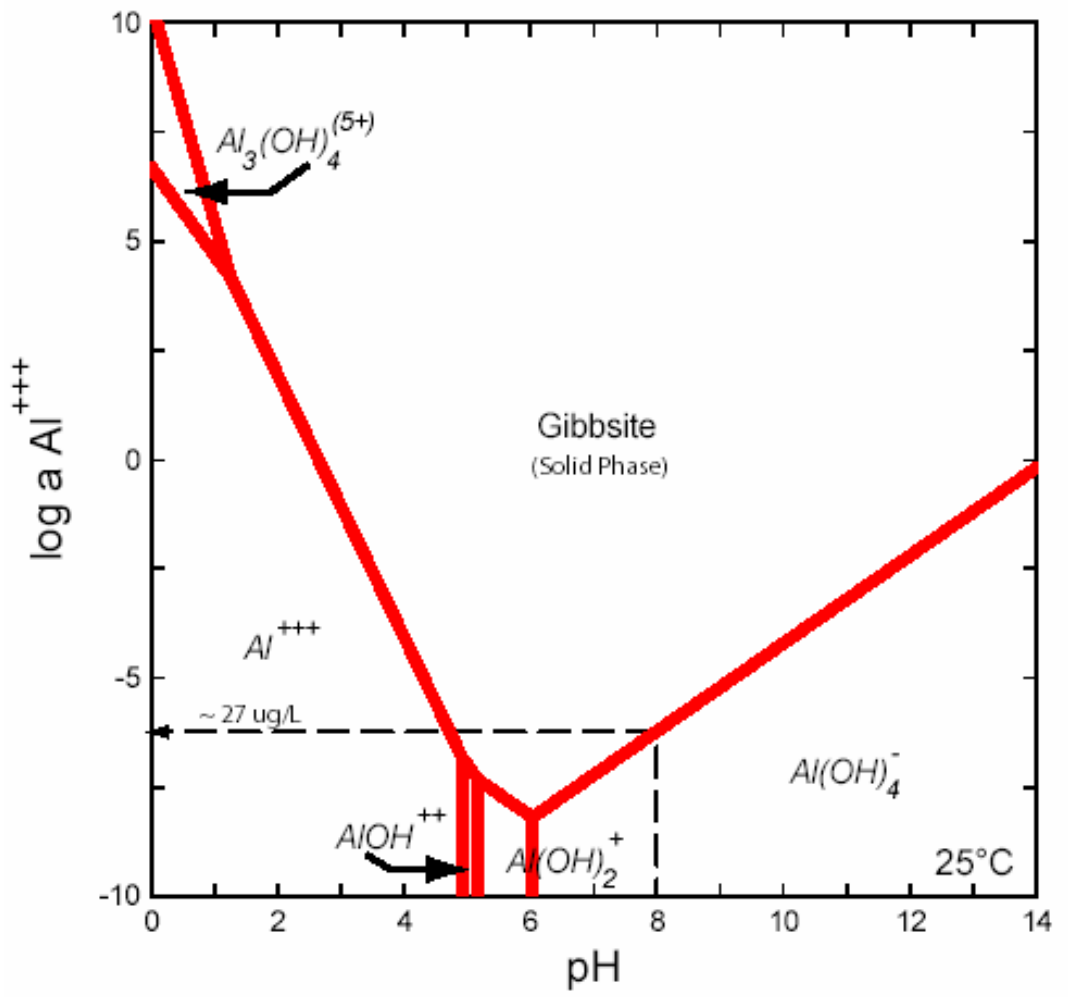

Figure 4.3. Dissolved Aluminum Concentrations as a Function of $\mathrm{pH}$ (Evan Dresel, personal communication, December 2001) 
when the turbidity was very high (916 NTU). The high concentrations of iron, manganese, and aluminum are deemed to be sampling related and not representative of the aquifer. The high turbidity was due to re-suspension of sediment in the bottom of a well that was going dry (this well was replaced by new well 299-W23-21). Apparently, the high particulate loading of the filter resulted in failure of the membrane, allowing particulates to pass through.

Other constituents of concern not listed in the table were previously analyzed in selected wells with the highest likelihood of occurrence (Johnson and Chou 2001). For example, groundwater samples from well 299-W23-234 near tank SX 108 and well 299-W23-19 near tank SX-115 were analyzed for iodine-129, neptunium-237, plutonium-238, -239, and -240, and americium-241 (all unfiltered samples). The vendor reported non-detect results for all these constituents. 


\subsection{Extent of Contamination}

Evaluation of the extent of contamination involves consideration of both vertical and areal distribution of contaminant concentrations. Vertical distribution at Waste Management Area S-SX was reported in the previous assessment report (Johnson and Chou 2001). Some new information related to vertical extent also was acquired for this report but the primary emphasis is on areal extent based on:

- data from existing wells and new wells installed to fill gaps along the S and SX tank farm fence lines

- data from new wells that allow better delineation of the lateral extent of the technetium-99 plume originating from the south end of the SX tank farm.

A review of previous and new vertical information is discussed first, followed by a discussion of areal distribution based on both observed and predicted results.

\subsection{Vertical Distribution}

Discrete depth sampling during drilling in 1999 suggested that most of the tank waste contaminants were within the upper 5 to 10 meters of the aquifer at the south end of this waste management area (Johnson and Chou 2001). Most of these data were acquired during air rotary drilling that allowed collection of multiple discrete-depth samples. A field screening method for technetium-99 (Beals et al. 2001) also was demonstrated in the field during the above air rotary drilling, providing discrete depth data in the field as the well was advanced. Only very limited discrete depth sampling was possible during the current report period since the cable tool method was used for most of the well drilling. However, some opportunity was provided to compare the very top of the aquifer (upper $\sim 0.5$ meter) with results for samples pumped from a 5- or 10-meter screened interval, discussed in the following paragraph.

Some reviewers (tank farm expert panel) postulated that tank farm contaminants at the SX tank farm may be wide spread but were missed because of either the long well screens (dilution of the signal) or deeper pump intakes that missed the major zone of contamination. To investigate this hypothesis, three well pairs (a well going dry and its replacement) were sampled at the same time, thus allowing comparison of contaminant concentrations at the very top of the aquifer with concentrations pumped from a relatively long screened interval. Results are shown in Table 5.1. Technetium-99 concentrations in the downgradient pair at the SX tank farm are very low and about the same concentration. This suggests that at this location, a major contaminant plume was not missed due to the use of sample pump intakes that are set too far below a thin contaminant layer at the top of the aquifer.

Contaminants in the upgradient well pairs indicate concentrations are a factor of 2 or 3 higher in the shallow well as compared to concentrations in the deeper wells. There appears to be dilution due to mixing from sampling across the long well screen at these upgradient locations (Martin-Hayden and Robbins 1997). But even in this case, the contaminants were not missed. Some dilution of the signal can be expected, especially in a heterogeneous aquifer (see discussion in Chapter 2). 
Table 5.1. Comparison of Concentrations in Shallow and Deep Wells at Waste Management Area S-SX

\begin{tabular}{|c|c|c|c|c|c|c|}
\hline \multirow[b]{2}{*}{$\begin{array}{l}\text { Constituent } \\
\text { (Unit) }\end{array}$} & \multicolumn{2}{|c|}{$\begin{array}{l}\text { Upgradient Pair } \\
\text { (S Farm) }\end{array}$} & \multicolumn{2}{|c|}{$\begin{array}{l}\text { Upgradient Pair } \\
\text { (SX Farm) }\end{array}$} & \multicolumn{2}{|c|}{$\begin{array}{c}\text { Downgradient Pair } \\
\text { (SX Farm) }\end{array}$} \\
\hline & $\begin{array}{l}\text { W23-13 }{ }^{\text {(a) }} \\
\text { (Shallow) }\end{array}$ & $\begin{array}{l}\text { W23-20(b) } \\
\text { (Deep) }\end{array}$ & $\begin{array}{l}\text { W23-14 }{ }^{(\mathrm{a})} \\
\text { (Shallow) }\end{array}$ & 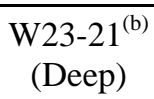 & $\begin{array}{l}\text { W22-39(a) } \\
\text { (Shallow) }\end{array}$ & $\begin{array}{c}\text { W22-49 }{ }^{(\mathrm{c})} \\
\text { (Deep) }\end{array}$ \\
\hline Uranium $(\mu \mathrm{g} / \mathrm{L})$ & 15 & 5.4 & 14.8 & 11 & 4.6 & 3.6 \\
\hline Tritium (pCi/L) & $152 \mathrm{U}$ & $40 \mathrm{U}$ & 100,000 & 48,600 & 28,300 & 24,500 \\
\hline Technetium-99 (pCi/L) & $0 \mathrm{U}$ & $0 \mathrm{U}$ & 36.9 & 29.2 & 115 & 86.4 \\
\hline Nitrate $(\mu \mathrm{g} / \mathrm{L})$ & 8,411 & 3,537 & 62,860 & 46,039 & 21,249 & 11,952 \\
\hline Chromium $(\mu \mathrm{g} / \mathrm{L})$ & 5.7 & 5.7 & 8.1 & 3.9 & 9.8 & 5.7 \\
\hline Sodium $(\mu \mathrm{g} / \mathrm{L})$ & 20,600 & 21,700 & 28,800 & 26,100 & 23,700 & 23,000 \\
\hline Calcium ( $\mu \mathrm{g} / \mathrm{L})$ & 21,200 & 17,600 & 33,600 & 32,800 & 19,500 & 18,200 \\
\hline Alkalinity $(\mu \mathrm{g} / \mathrm{L})$ & 94,000 & 86,000 & 82,000 & 66,000 & 86,000 & 92,000 \\
\hline \multicolumn{7}{|c|}{$\begin{array}{l}\text { Note: All well numbers prefixed by } 299 \text {. U denotes analytical result is not detected. Results in the table for shallow } \\
\text { wells W23-13, W23-14, and W22-39 were collected from the last sampling events on 01/8/01, 12/29/00, and 01/8/01, } \\
\text { respectively (all three wells went dry). Results in the table for deep wells W23-20, W23-21, and W22-49 were } \\
\text { collected on 03/8/01, 03/19/01, and 01/8/01, respectively. } \\
\text { (a) } 1-2 \mathrm{ft} \text { screen. } \\
\text { (b) } 35 \text {-ft screen length. } \\
\text { (c) } 15 \text {-ft screen length. }\end{array}$} \\
\hline
\end{tabular}

\subsection{Areal Distribution}

The most recent concentrations of technetium-99, the primary indicator of mobile tank waste, in the completed well network are shown in Figure 5.1. Data for the two most recently installed wells (299-W22-84 and 299-W22-85) are based on samples collected during drilling and development. Results for these two wells are provisional. Observed areal distribution is discussed separately for the $S$ and SX tank farm areas followed by a comparison of observed and predicted technetium-99 plume concentrations at the south end of the SX tank farm.

\subsubsection{S Tank Farm Area}

Technetium-99 in a sample collected during drilling at well 299-W22-85 (located along the northern, downgradient fence line) was at or near the detection limit. This is the first time groundwater in this area has been available. There was some concern that groundwater contamination may exist in this area due to a past spill from a transfer line in the SY farm and the diversion box (241-S-152) at the north end of the $\mathrm{S}$ tank farm. With this new well in place, this area of the waste management area is now covered.

Elevated technetium-99 concentrations occur in the relatively new well 299-W22-48. In contrast, concentrations are relatively low in the wells immediately north (well 299-W22-44) and south (well 


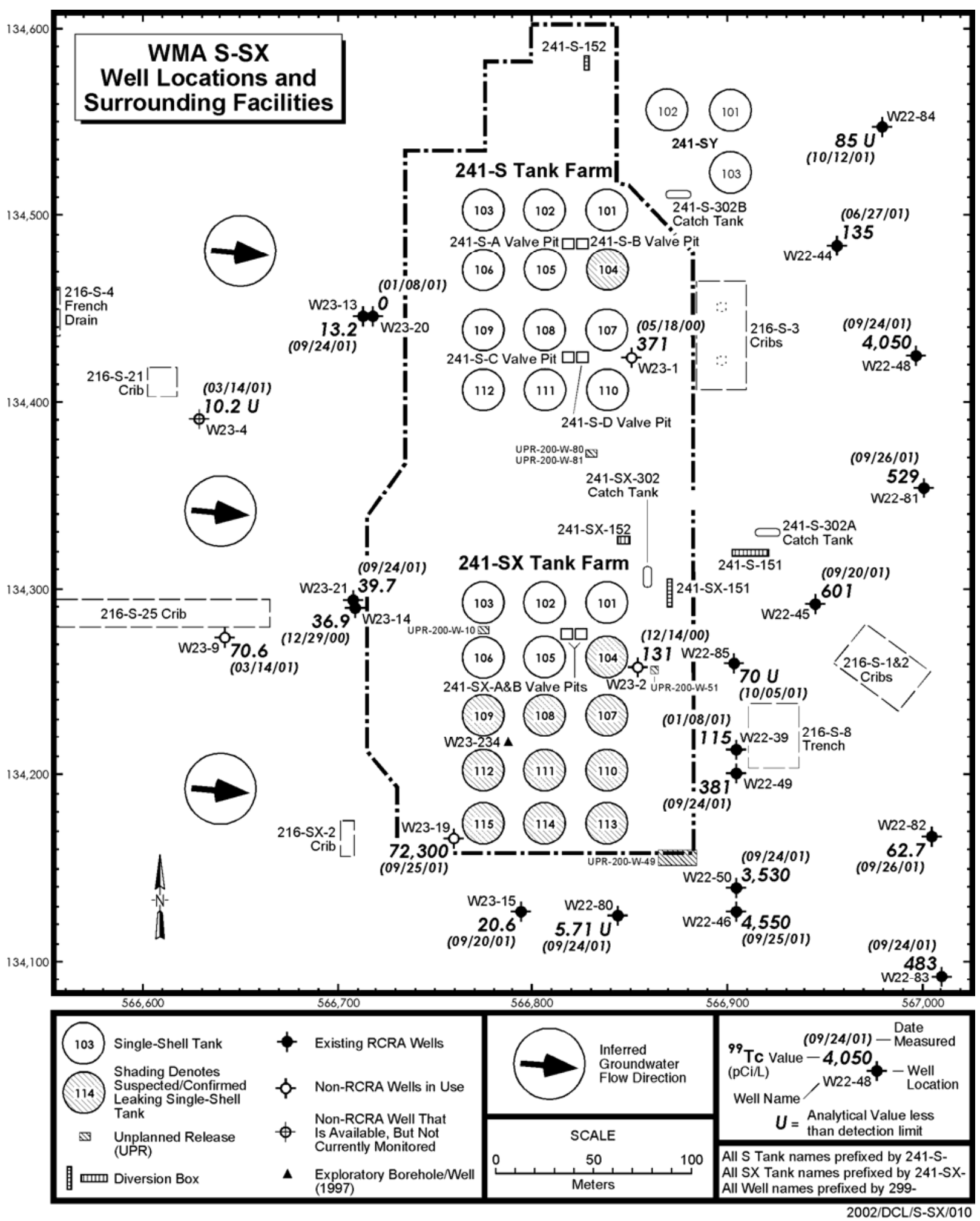

Figure 5.1. Areal Distribution of Technetium-99 at Waste Management Area S-SX 
299-W22-81) of well 299-W22-48. The distance between wells at this location is $\sim 60$ meters. Thus, the contaminant plume must be somewhat narrow. The sharp upward trend in technetium-99 concentrations at well 299-W22-48 (see Figure 4.1) also suggests relatively little dispersion has occurred between the source and the well (see Section 5.3 discussion of the significance of sharp breakthrough curves).

While technetium-99 concentrations are low in well 299-W22-44, the sharp upward trend suggests the recent arrival of a groundwater plume in this area of the tank farm (Figure 5.2). Valve pits and tank S-104, the only tank designated as leaking in S tank farm, are upgradient from wells 299-W22-44 and 299-W22-48.

In addition to technetium-99 distribution, tritium provides some important information concerning areal distribution and groundwater movement in the $S$ tank farm area. For example, in contrast to the SX tank farm area, tritium is virtually absent (see Table 4.1) in the S tank farm and vicinity. More importantly, there is no upgradient source (based on upgradient wells 299-W23-13 and W23-20). Any tank farm contribution of tritium should be evident in the $\mathrm{S}$ tank farm downgradient monitoring wells. Detectable tritium (maximum of 1,460 pCi/L, see Table 4.1) was observed in just one well (299-W22-48) in the $\mathrm{S}$ tank farm area. This well is also currently showing increasing trends in technetium-99, chromium, and nitrate (see Figure 4.1).

The areal distribution of uranium also reflects the past-practice, upgradient sources. However, unlike tritium, residual upgradient sources of uranium occur in the S tank farm area. For example, the 216-U-14 ditch, which passed along the northwestern side of the S tank farm, carried wastewater from the U Plant

299-W22-44 Technetium-99 (pCi/L)

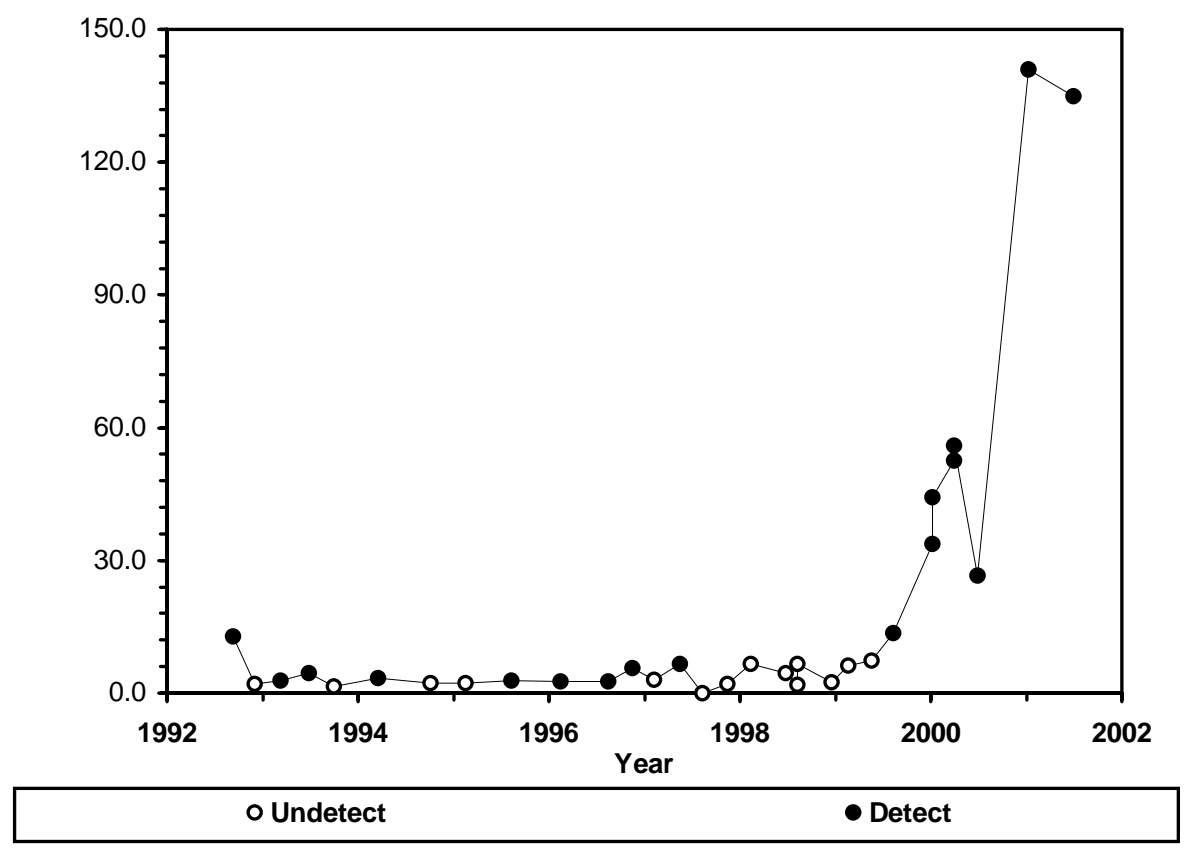

Figure 5.2. Technetium-99 Concentration in Well 299-W22-44 at S Tank Farm 
to U Pond. Spills of uranium-bearing waste released to the ditch during the operational period may account for the apparent upgradient source in this area. The areal distribution of both tritium and uranium are consistent with the inferred flow direction (i.e., west to east or east-southeast).

\subsubsection{SX Tank Farm Area}

Contrary to expectations, no significant new contamination was found in new well 299-W22-85 located midway along the eastern fence line of the SX tank farm. This well is located downgradient from spill sites as well as tanks that have leaked in the past. Either groundwater contamination existed in this area but passed by, or it has not yet arrived (or it has not broken through the vadose zone to groundwater). Whichever the case, the gap in spatial coverage at this important location has been eliminated.

The distribution of technetium-99 in the SX tank farm area continues to be dominated by the source in the southwest corner near or at tank SX-115 (i.e., at well 299-W23-19). The new downgradient wells (299-W22-80, 299-W22-82, and 299-W22-83) help to define the transverse and longitudinal distribution of the assumed plume emanating from the vicinity of tank SX-115. The low concentrations observed thus far in the two new mid-field downgradient wells (299-W22-82 and 299-W22-83) suggest the assumed contaminant plume must be fairly restricted in areal extent. However, given the limited number of monitoring wells, predicted plume distribution patterns would be very useful. An initial attempt to provide such information is described in the following section.

\subsubsection{Predicted Areal Extent}

As already noted, one of the major objectives of the RCRA assessment is to evaluate the areal extent of contamination. However, the cost of an adequate density of wells to fully delineate plume dimensions is prohibitive. Predictive modeling provides one means of extending the limited well point data available. If there is concordance between predicted and observed data at a few well locations, more reliance on predicted plumes to aid in evaluation of the extent of contamination can be made.

Spatial domain. The highest and most persistent groundwater contaminant concentrations occur at the southern end of Waste Management Area S-SX, where tank leaks have occurred in the past. This is also the area where old pressurized water-supply lines that are suspected of leaking pass near some of the waste tanks with soil column contamination. Thus, this portion of the waste management area is of particular interest for interim corrective measures and remediation (such as eliminating sources of infiltrating water and conducting groundwater pump and treat). The scale of interest chosen for predicting plume dimensions is 75 meters wide by 200 meters long beginning at tank SX-115.

Approach. Plume modeling requires dispersivity values at the scale of interest as input parameters to the model. Since such information does not exist for the study site, a curve matching approach was first used to estimate dispersivities at the appropriate scale. Efforts were first directed at matching model predicted concentrations with an observed downgradient time-concentration pattern from which apparent dispersivity can be extracted. Technetium-99 in well 299-W22-46 (Figure 5.3) was assumed to represent the arrival and continued passing of a plume from the SX-115 tank area. The variable but persistent elevated concentrations over time indicate there is a quasi-continuous upgradient release. The well is 
located $\sim 125$ meters directly downgradient from tank SX-115, the assumed source. Travel time from the tank location to well 299-W22-46 is estimated to be over 6 years at a nominal flow rate of 0.06 meter per day. The lower initial concentrations (from 1992 and 1996) may be due to another upgradient crib source.

A three-dimensional, analytical dispersion model (PLUME -3D, Van der Heijde and Beljin 1998) was used (1) to simulate the contaminant arrival time of technetium-99 at well 299-W22-46, (2) to approximate the plume shape, and (3) to help estimate the lateral extent of contamination from the source area. As noted in Van der Kamp et al. (1994), simulation of contaminant arrival times and breakthrough patterns at known well distances from the contaminant source is particularly valuable for determining groundwater flow velocity and longitudinal dispersion.

The analysis procedure included an initial simulation of the technetium-99 contaminant arrival time profile at well 299-W22-46 (see Figure 5.3) to obtain preliminary estimates for hydrologic and transport parameters (e.g., groundwater-flow velocity, longitudinal and transverse dispersivities) within the contaminant plume area. Well 299-W22-46 is located near the plume center and 125 meters from the contaminant source.

299-W22-46 Technetium-99 (pCi/L)

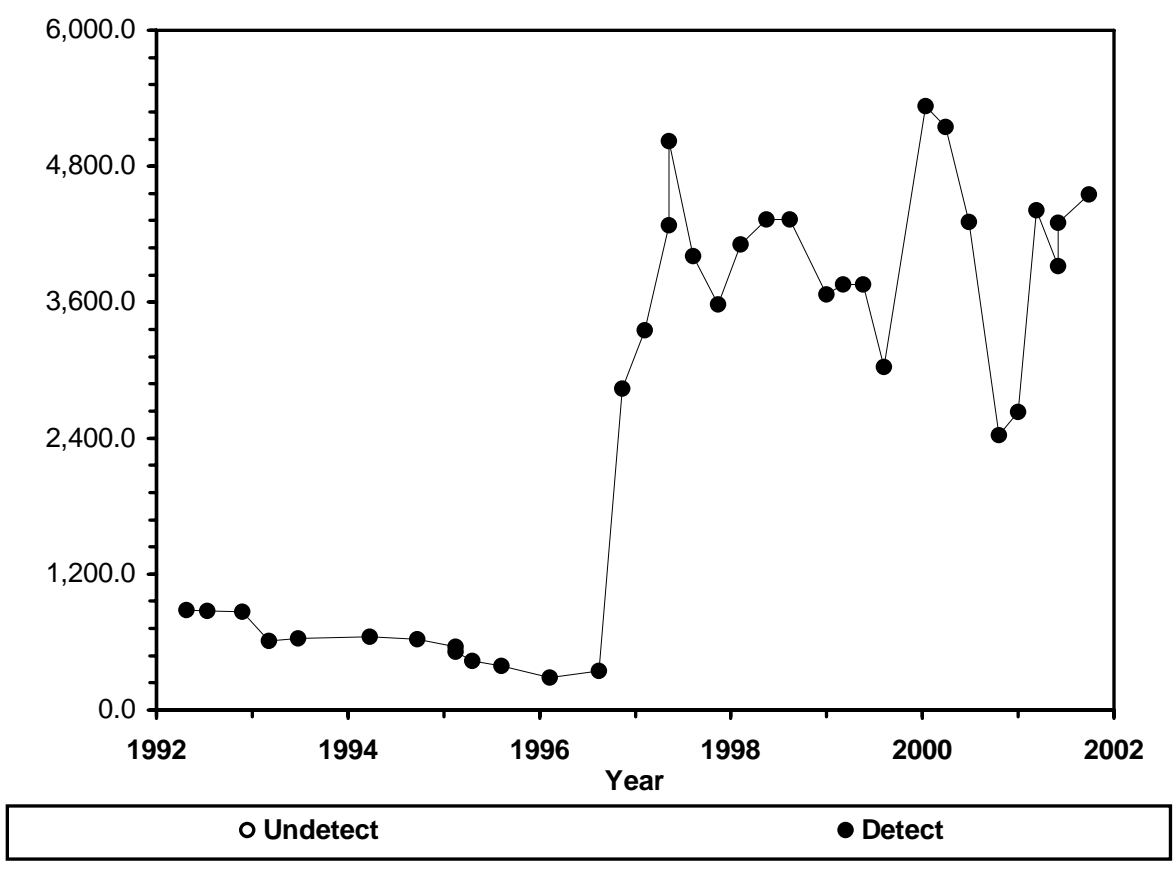

Figure 5.3. Technetium-99 Concentration in Well 299-W22-46 at SX Tank Farm 
For initial input parameters for the simulation, the following values were used:

- A contaminant source input rate ranging between 6.6E-6 and 6.6E-7 kilograms per day (based on vadose zone core sample data from the tank leak site, a source area of $400 \mathrm{~m}^{2}$, base area of a singleshell tank, and an infiltration rate of 10 centimeters per year)

- Ambient groundwater flow velocities ranging between 0.03 and 0.10 meter per day and an aquifer effective porosity of 0.25 (based on single-tracer test results: Spane et al. 2001)

- Transverse and longitudinal dispersivities of 1.2 and 8.5 meters, respectively (empirically derived from existing contaminant plumes in the vicinity, Wilson et al. 1992)

- An initial contaminant input date of circa 1990 (from Johnson and Chou 2001)

- A constant flow direction of 15 degrees south of due east (based on water level data for the nearest wells; Spane et al. 2001)

- Homogenous aquifer properties are assumed and concentrations were computed for the top of the aquifer where the highest technetium-99 concentrations have been observed (Johnson and Chou 2001).

The driving force for transporting contaminant from the tank to groundwater is assumed to be either enhanced natural infiltration or a leaking water line as depicted in Figure 5.4a. The single-shell tank (SX-115) is in a direct line of predicted flow to downgradient well 299-W22-46 (and adjacent well 299-W22-50).

Soil column characterization at borehole 48B revealed very high levels of cesium-137 (up to $1 \mathrm{E}+08 \mathrm{pCi} / \mathrm{g}$; Raymond and Shdo 1966) just beneath the bottom elevation of tank SX-115 (illustrated as the red patch in Figure 5.4a). Mobile tank waste (technetium-99, nitrate, and chromium), however, were distributed downward to a much greater extent and assumed to eventually reach the water table. The blue area in Figure 5.4a indicates hypothetical distribution of infiltrating water and water-soluble tank waste. The water table is at about 65 meters below ground surface at this location.

The water line piping diagram (Figure 5.4b) shows the proximity of a 6- and 8-inch water line to the single-shell tanks along the southern fence line of the SX tank farm. These old water distribution lines were pressurized over an unknown time period but were capped and sealed permanently on April 25, 2001.

If seepage of water from these old lines acted as the primary driving force for transporting tank waste to groundwater at this location, technetium-99 concentrations should start to decline in well 299-W23-19 in the near future. 


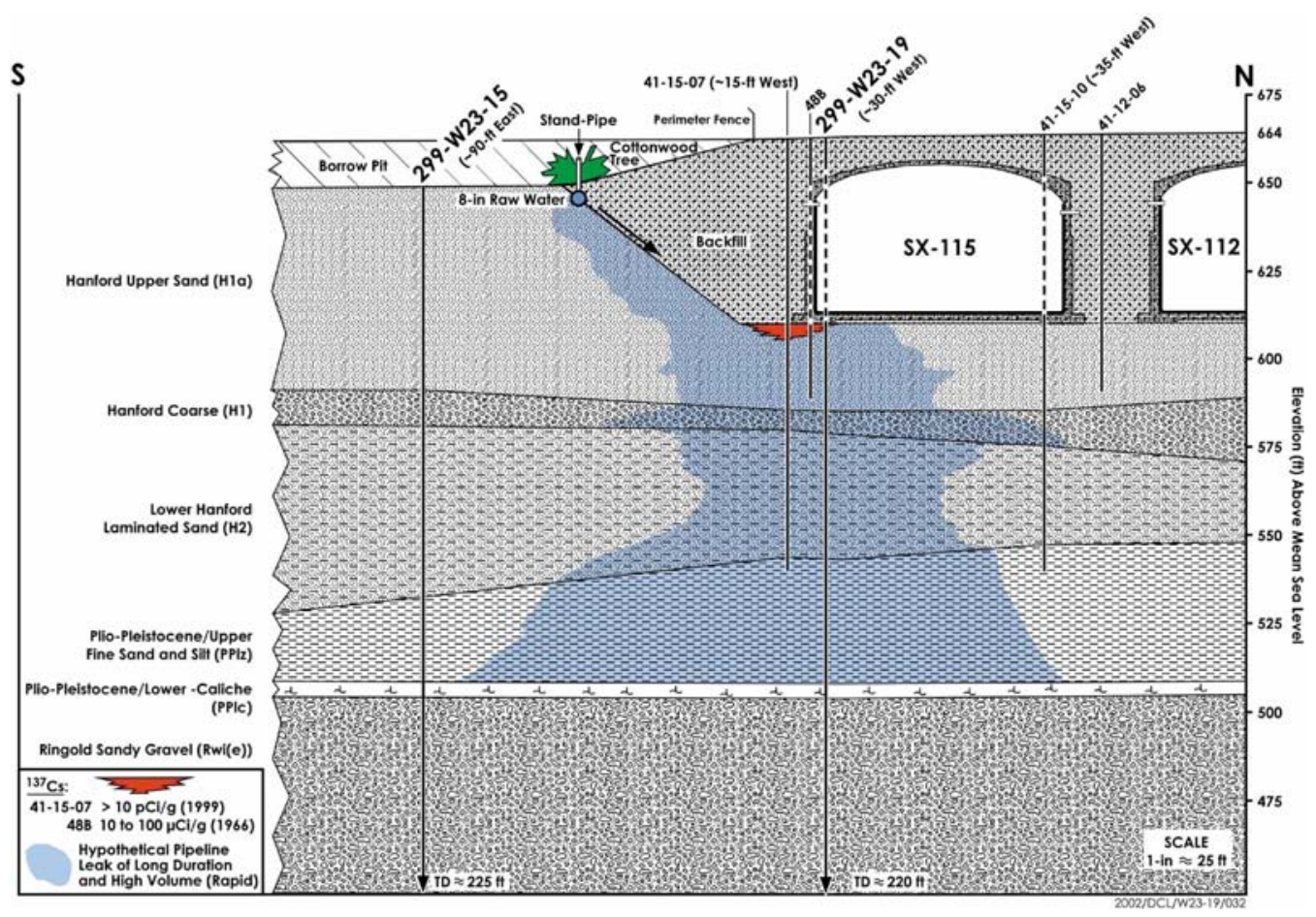

Figure 5.4a. Conceptual Model of Tank Waste Transport through Vadose Zone to Groundwater at Tank SX-115

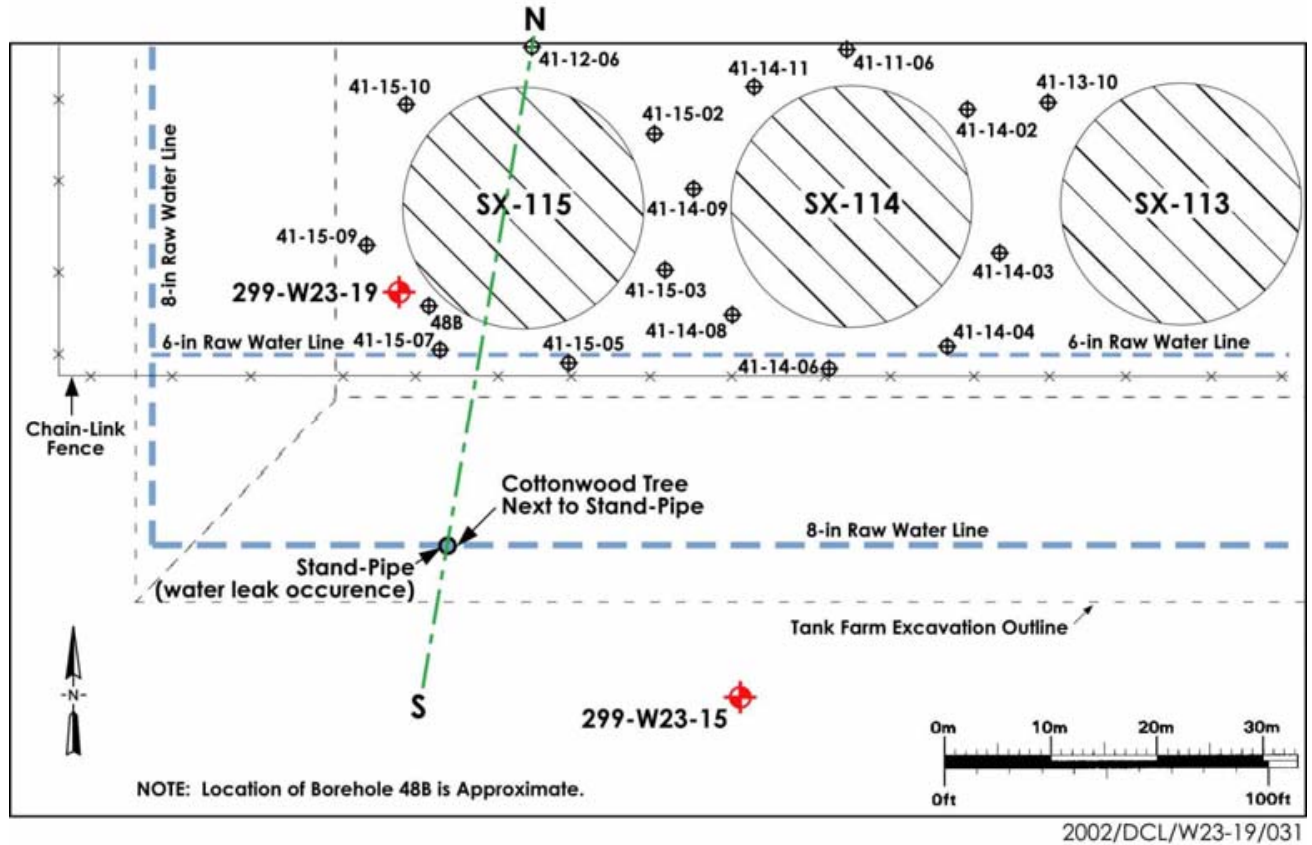

Figure 5.4b. Location of Water Lines at Southern End of SX Tank Farm (Pipeline locations are based on engineering drawings. Incomplete geophysical surveys suggest the 8-inch and 6-inch lines may have passed closer to tank SX-115 than shown.) 
The abrupt contaminant arrival-time profile exhibited in Figure 5.5 for well 299-W22-46 suggests that very little dispersion (spreading or mixing) is occurring along the contaminant plume flow front. Simulation efforts in using the initial input values for dispersivity were not successful in matching the observed arrival-time profile. Consequently, dispersivities had to be lowered significantly to match the observed pattern. The effects of channelization (i.e., boundaries) that commonly occur in alluvial-type aquifers and uniformity of groundwater flow conditions has been noted by others (e.g., Van der Kamp et al. 1994) as a possible cause for low calculated dispersion values, particularly transverse dispersivity. In addition, the relatively small area investigated may be contributing to the low calculated dispersivity values and may not be representative of larger scale transport behavior. The scale dependency of dispersivity has been previously noted by others (Palmer and Johnson 1989). Figure 5.6 shows the best simulation match for the observed technetium-99 arrival-time profile. The observed data were corrected for a small background technetium-99 value attributed to other surrounding sources, which was shown to occur previously in Figure 5.3 prior to contaminant breakthrough. The input parameters used in the simulation match include: groundwater-flow velocity of 0.05 meter per day, effective porosity of 0.25 , longitudinal and transverse dispersivities of 0.5 meter, and a contaminant source term of $2.0 \times 10^{-6}$ kilograms per day (34 $\mu \mathrm{Ci} / \mathrm{day})$.

To examine whether the dispersion parameters are reasonable for the area examined, a comparison with the observed technetium-99 concentrations in monitoring wells within the predicted path of the contaminant plume was undertaken. Technetium-99 concentrations observed for March-June 2001 are shown together with the predicted areal distribution (see Figure 5.6). As indicated, there is reasonable agreement between the predicted and observed well data. The slight deviation in observed data from the

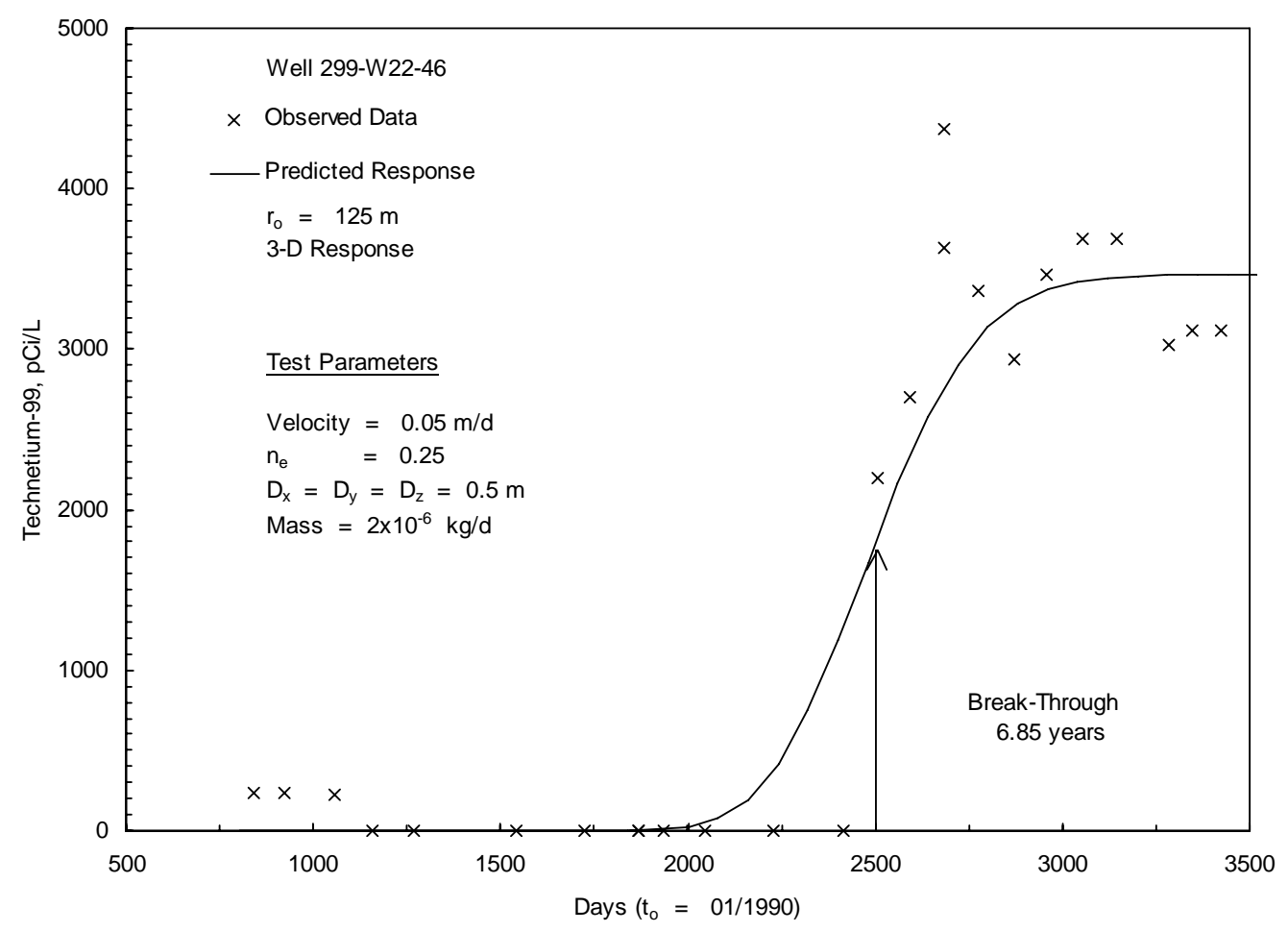

Figure 5.5. Predicted versus Observed Contaminant Arrival Time Response 


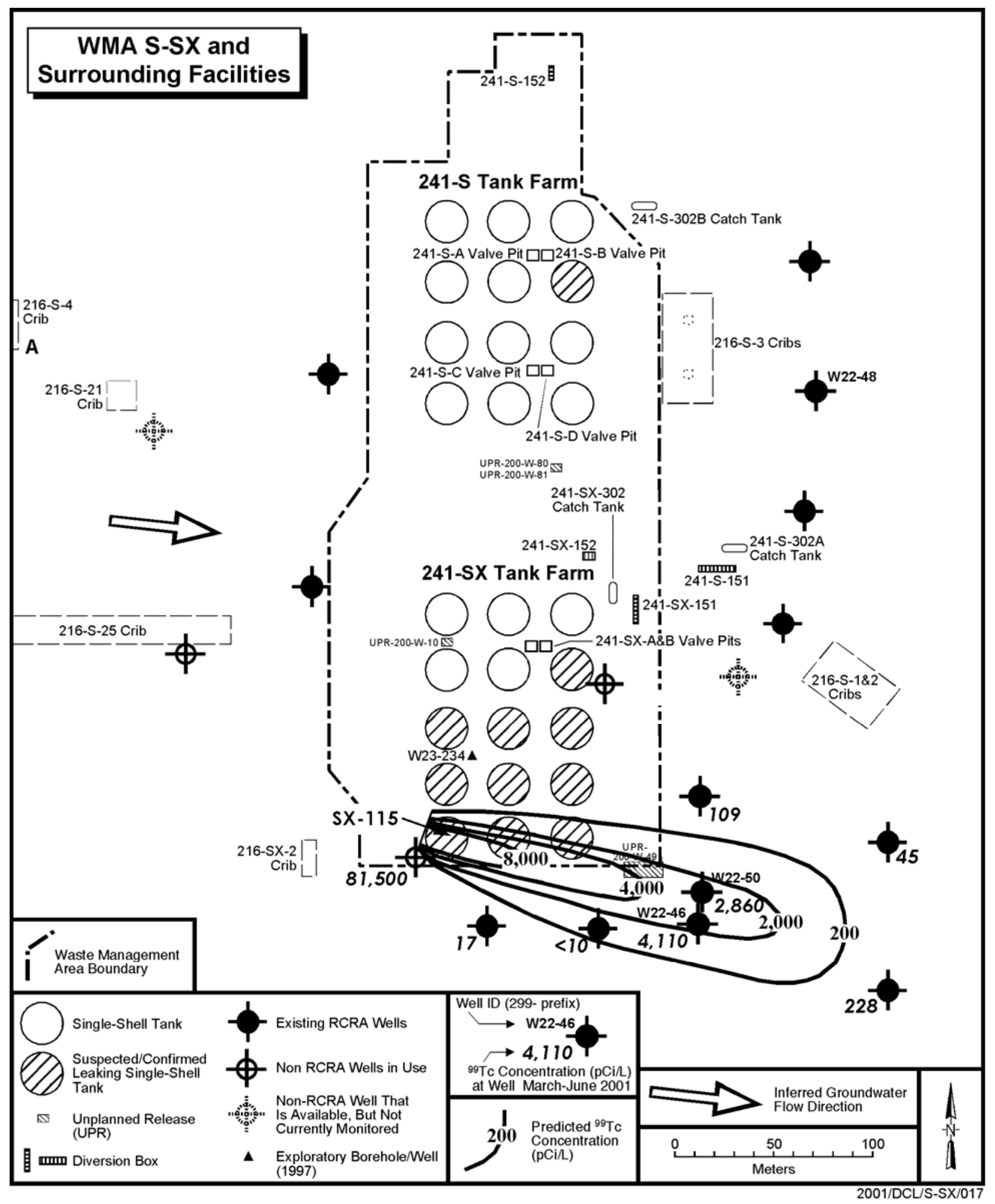

Figure 5.6. Predicted Technetium-99 Plume Downgradient from the Source Area Near Tank SX-115 
predicted symmetrical plume shape (along southern edge of the plume) may be attributed to local heterogeneities within the aquifer, or to a progressive change in groundwater flow direction (i.e., more easterly), which has been observed for this site over the past 10-year period. Nevertheless, the analytical model does approximate the general shape suggested by the observed distribution.

The predicted and observed technetium-99 suggest that dispersal of contamination in groundwater from the southwestern corner of the waste management area is very limited in both its longitudinal and transverse directions and migrates at a very slow rate. The slow rate of movement is consistent with the low hydraulic conductivities (see Chapter 3) especially those close to or within the southern end of the SX tank farm. 


\subsection{Summary and Conclusions}

Installation of eight new monitoring wells at Waste Management Area S-SX completes the well spacing needs previously identified (Johnson and Chou 2001). No significant new contamination was discovered at the new well sites. However, rapidly increasing concentrations of technetium-99 and associated mobile tank waste contaminants were detected in two wells at $\mathrm{S}$ tank farm.

Technetium-99 remains as the constituent with the highest concentration relative to a drinking water standard. Well 299-W23-19 at tank SX-115 continues to exhibit elevated concentrations with a maximum of $81,500 \mathrm{pCi} / \mathrm{L}$ relative to the drinking water standard of $900 \mathrm{pCi} / \mathrm{L}$. Interim corrective measures (conducted by CH2M HILL Hanford Group, Inc.) included

- permanently cutting and capping old pressurized water lines in close proximity to the source of contamination near tank SX-115

- surface run-on controls (berming and diversion ditches).

The water line work was completed on April 25, 2001. A downward trend in contaminant concentrations in groundwater in well 299-W23-19, located next to tank SX-115, has not been observed as of September 2001. However, there is no longer an upward trend in technetium-99, chromium, and nitrate as observed prior to the corrective measures work.

As noted above, technetium 99 concentrations in downgradient wells at $\mathrm{S}$ tank farm indicate rapidly increasing concentrations in two wells (299-W22-44, and 299-W22-48). The technetium-99 concentration in the latter well is over $4,000 \mathrm{pCi} / \mathrm{L}$. The steeply rising concentrations suggest a nearby source and or that very little dispersion is occurring between the source and the well.

Evaluation of the extent of the apparent contaminant plume at the southern end of the SX tank farm suggests the rate of movement is very slow and the contaminant plume concentrations of concern are limited in extent. Predicted areal distribution is consistent with contaminant concentrations in the observation wells within the boundaries of the theoretical concentration contours, lending confidence in the predictive modeling approach used.

Based on the predicted technetium-99 concentration contours, the areal extent of groundwater contamination that exceeds the cleanup target level of $9,000 \mathrm{pCi} / \mathrm{L}$ is estimated to be equivalent to the area of two single-shell tanks (about $800 \mathrm{~m}^{2}$ ). The very low hydraulic conductivities in the southwestern area of the SX tank farm suggest that movement of contaminants that reach the water table in this area may be hydraulically contained or at least severely restricted in lateral movement.

The groundwater quality assessment at Waste Management Area S-SX has matured from a detection phase to assessment and characterization followed by interim corrective measures. Groundwater monitoring at this site in the future should help to assess the efficacy of the corrective measures that were undertaken to reduce or eliminate sources of groundwater contamination within Waste Management Area S-SX. 


\subsection{References}

40 CFR 265, Title 40, Part 265. "Interim Status Standards for Owners and Operators of Hazardous Waste Treatment, Storage, and Disposal Facilities.” Code of Federal Regulations.

Beals, D. M, K. J. Hofstetter, V. G. Johnson, G. W. Patton, and D. C. Seely. 2001. "Development of Field Portable Sampling and Analysis Systems.” Journal of Radioanalytical and Nuclear Chemistry 28(2):315-319.

Connelly, M. P., B. H. Ford, and J. V. Borghese. 1992. Hydrogeologic Model of 200 West Groundwater Aggregate Area. WHC-SD-EN-TI-014, Rev. 0, Westinghouse Hanford Company, Richland, Washington.

Ecology - Washington State Department of Ecology, U.S. Environmental Protection Agency and U.S. Department of Energy. 1998. Hanford Federal Facility Agreement and Consent Order. Document No. 89-10, Rev. 5 (The Tri-Party Agreement), Olympia, Washington.

Horton, D. G. and V. G. Johnson. 2001. Borehole Data Package for Calendar Year 2000-2001 RCRA Wells at Single-Shell Tank Waste Management Area S-SX. PNNL-13589, Pacific Northwest National Laboratory, Richland, Washington.

Johnson, V. G. and C. J. Chou. 1998. Results of Phase I Groundwater Quality Assessment for SingleShell Tank Waste Management Area S-SX at the Hanford Site. PNNL-11810, Pacific Northwest National Laboratory, Richland, Washington.

Johnson, V. G. and C. J. Chou. 1999a. RCRA Assessment Plan for Single-Shell Tank Waste Management Area S-SX at the Hanford Site. PNNL-12114, Pacific Northwest National Laboratory, Richland, Washington.

Johnson, V. G. and C. J. Chou. 1999b. Addendum to the RCRA Assessment Report for Single-Shell Tank Waste Management Area S-SX at the Hanford Site (PNNL-11810), ADD. 1, PNNL-12114, Pacific Northwest National Laboratory, Richland, Washington.

Johnson, V. G. and C. J. Chou. 2001. RCRA Groundwater Quality Assessment Report for Waste Management Area S-SX. PNNL-13441, Pacific Northwest National Laboratory, Richland, Washington. (http://www.pnl.gov/main/publications/external/technical_reports/PNNL-13441f).

Martin-Hayden, J. M. and G. A. Robbins. 1997. "Distortion and Apparent Attenuation Due to Concentration Averaging in Monitoring Wells.” Ground Water 35(2):339-346.

Palmer, C. D. and R. L. Johnson. 1989. "Physical Processes Controlling the Transport of Contaminants in the Aqueous Phase." In: Transport and Fate of Contaminants in the Subsurface, EPA 625/4-89/019. 
Raymond, J. R. and E. G. Shdo. 1966. Characterization of Subsurface Contamination in the SX Tank Farm. BNWL-CC-701, Battelle Northwest Laboratory, Richland, Washington.

RCRA - Resource Conservation and Recovery Act. 1976. Public Law 94-580, as amended, 90 Stat. 2795, 42 USC 6901 et seq.

Spane, F. A., Jr., P. D. Thorne, and D. R. Newcomer. 2001. Results of Detailed Hydrologic Characterization Tests - FY 2000. PNNL-13514, Pacific Northwest National Laboratory, Richland, Washington.

Van der Heijde, P.K.M. and M. S. Beljin. 1998. Solute: Analytical Models for Solute Transport in Ground Water. Version 4.06, International Ground Water Modeling Center, Golden, Colorado.

Van der Kamp, G., L. D. Luba, J. A. Cherry, and H. Maathuis. 1994. “Field Study of a Long and Very Narrow Contaminant Plume.” Ground Water 32(6):1008-1016.

WAC 173-303. Dangerous Waste Regulations. Washington Administrative Code, Olympia, Washington.

Wilson, C. R., C. M. Einberger, R. L. Jackson, and R. B. Mercer. 1992. "Design of Ground-Water Monitoring Networks Using the Monitoring Efficiency Model (MEMO).” Ground Water 30(6):965-970. 


\section{Appendix A}

\section{Hydraulic Conductivity Estimates in Waste Management Area S-SX}




\section{sallelle \\ ... Putting Technology To Work}

Project No. $\underline{\text { F29504 }}$

\begin{tabular}{|c|c|c|}
\hline Date & April 14, 2005 & $\begin{array}{l}\text { S.P. Luttrell } \\
\text { D.R. Newcomer }\end{array}$ \\
\hline To & V.G. Johnson & $\begin{array}{l}\text { R.M. Smith } \\
\text { P.D. Thorne }\end{array}$ \\
\hline From & F.A. Spane & PFile/LB \\
\hline Subject & $\begin{array}{l}\text { Summary of Hydraulic Conductivity Estimates } \\
\text { Obtained From Recent Hydrologic Characterization } \\
\text { Tests Conducted in the } \\
\text { WMA S-SX }\end{array}$ & \\
\hline
\end{tabular}

This letter report presents a summary of hydraulic conductivity estimates obtained from recent hydrologic characterization tests conducted within the WMA S-SX over the past three years as part of PNNL's detailed characterization program. These estimates include those results reported previously in Spane et al. (2000), as well as test results that are in the process of being formally documented in subsequent PNNL technical reports. This letter report is being issued as an interim measure to meet current hydrologic data needs of the WMA S-SX project, prior to formal technical report issuance. The letter report only provides the hydraulic conductivity estimates for the various detailed hydrologic characterization test elements, and does not present discussions pertaining to test descriptions, and analytical methods and result comparison. These discussions will be presented in detailed fashion in the subsequent PNNL technical reports.

\section{Detailed Hydrologic Characterization Program}

As part of the Hanford Groundwater Monitoring Project, Pacific Northwest National Laboratory conducts detailed hydrologic characterization tests in wells at selected locations to provide information pertaining to the hydraulic properties and groundwater flow characteristics of the unconfined aquifer. The following identifies and briefly describes the various characterization components employed in FY-99 through FY-01, as part of the detailed hydrologic characterization program. Various individual test element activities include:

$\begin{array}{ll}\text { Groundwater Flow } & \text { for quantitative determination of groundwater flow } \\ \text { Characterization: } & \text { direction and hydraulic gradient conditions }\end{array}$

Barometric Response for determining well response characteristics to barometric Evaluation: fluctuations; for estimating vadose zone transmission characteristics; and for removal of barometric pressure effects from hydrologic test responses 
Slug Testing:

Tracer-Dilution Test: for evaluating well development conditions and to provide preliminary hydraulic property information (e.g., hydraulic conductivity) for design of subsequent hydrologic tests

for determining the vertical distribution of hydraulic conductivity and/or groundwater flow velocity within the well-screen section, and for identifying vertical flow conditions within the well column

Tracer-Pumpback Test: for tracer removal and characterizing effective porosity, an important hydraulic transport parameter

\section{Constant-Rate Pumping Test:}

conducted in concert with tracer-pumpback phase. Analysis of drawdown and recovery data provides quantitative, large-scale hydraulic characterization property information (e.g., hydraulic conductivity, storativity, specific yield)

Step-Drawdown Test: for determining well efficiency and well loss for the well-screen section; for removal of well loss effects from hydrologic test response

for determining the existence of vertical flow within the wellscreen section
In-Well Vertical TracerTest:

Of the various individual test element activities, only slug testing and constant-rate pumping tests are relevant for the estimates of hydraulic conductivity that are provided in this letter report. Slug testing is designed primarily to provide initial estimates of hydraulic conductivity, $\mathrm{K}$, for the design of subsequent, more quantitative hydrologic tests, and for well development assessment. At each well, slug tests are conducted using at least two different stress levels to provide information pertaining to well development and possible presence of near-well heterogeneities. A detailed description of the design, performance and analysis of slug test characterizations is presented in Butler et al. (1994) and Butler (1997).

As noted above, constant-rate pumping tests are conducted as part of the single-well tracerdilution and pumpback tests. Pumping is commonly extended for a duration longer than required for capturing the tracer centroid emplaced within the aquifer. The extended pumping time enables quantitative large-scale characterization of the surrounding hydraulic properties (i.e., hydraulic conductivity). The time required to obtain representative hydrologic property results can be determined by using diagnostic derivative analysis results of the drawdown data obtained from the pumped and nearby observation well locations. A detailed description of the use of derivative analysis techniques is provided in Spane (1993) and Spane and Wurstner (1993).

Following termination of the constant-rate pumping test phase, the recovery of water levels within the pumped well and surrounding observation wells can also be monitored. The time 
required for recovery monitoring can be assessed in a manner similar to drawdown data collected during the pumping phase, through the use of diagnostic derivative analysis. For general planning purposes, however, recovery monitoring should be maintained for a period equal to the pumping period and preferably longer.

\section{Hydraulic Conductivity Results}

The S-SX monitor wells are all constructed of 10.16-cm-diameter stainless-steel casing with wirewrapped stainless-steel screens and sand pack. All wells are screened across the water table and penetrate approximately the top 3 to $10 \mathrm{~m}$ of the unconfined aquifer. The unconfined aquifer lies almost entirely within unit 5 of the Ringold Formation (geologic unit E) and is composed of fluvial, gravel-dominated sediments with a fine-sand matrix (Spane et al., 2000). Sediments within unit 5 exhibit variable degrees of cementation, ranging from partially to well developed. Thin, laterally discontinuous, sand and silt beds also are intercalated in the gravelly deposits.

Table 1 lists the analysis results for hydraulic conductivity (and transmissivity) determined from slug tests and constant-rate pumping tests. The range for $\mathrm{K}$ listed for slug tests represent the average $\mathrm{K}$ value as determined using the Bouwer and Rice method (Bouwer and Rice, 1976; Bouwer 1989) and the type-curve matching procedure, respectively. As discussed in Spane et al. (2000), the Bouwer and Rice method consistently provides lower K estimates, in comparison to the type-curve method. Constant-rate pumping test results include the analysis of drawdown and/or recovery data using the methods identified previously. A close correspondence in estimates for $\mathrm{K}$ is evident between the two test methods (i.e., slug and pumping tests), particularly when type-curve analysis estimates are used for the slug test results. It should also be noted that the test methods were analyzed completely independently from each other using different analysts, i.e., F.A. Spane: slug tests and P.D. Thorne: constant-rate pumping tests.

As shown, the average $\mathrm{K}$ values for slug testing ranged from a low of $0.7 \mathrm{~m} / \mathrm{d}$ (well 299-W23-21) to a high of $17.1 \mathrm{~m} / \mathrm{d}$ (well 299-W23-20). Approximately 65\% of the wells (i.e., 9 out of 14 wells) characterized by slug testing exhibit $\mathrm{K}$ values within the range of 1.0 to $10.0 \mathrm{~m} / \mathrm{d}$ (Figure 2). The geometric mean for $\mathrm{K}$ for the fourteen SX wells tested equals $2.54 \mathrm{~m} / \mathrm{d}$, with a standard deviation of $5.09 \mathrm{~m} / \mathrm{d}$.

\section{References}

Bouwer H. 1989. The Bouwer and Rice Slug Test - An Update. Ground Water, Vol. 27, No. 3, pp.304309.

Bouwer H, and RC Rice. 1976. A Slug Test for Determining Hydraulic Conductivity of Unconfined Aquifers with Completely or Partially Penetrating Wells. Water Resources Research Vol. 12, No. 3, pp. 423-428. 
Butler, J.J., G.C. Bohling, Z. Hyder, and C.D. McElwee. 1994. The Use of Slug Tests to Describe Vertical Variations in Hydraulic Conductivity. Journal of Hydrology, Vol 156, pp. 137-162.

Butler, J.J. 1997. The Design, Performance, and Analysis of Slug Tests. Lewis Publishers, Boca Raton, Florida, 252 p.

Spane, F.A., Jr., P.D. Thorne, and D.R. Newcomer. 2001. Results of Detailed Hydrologic Characterization Tests - FY 2000. PNNL-13514. Pacific Northwest National Laboratory, Richland, Washington.

Spane, F.A., Jr. and S.K. Wurstner. 1993. DERIV: A Program for Calculating Pressure Derivatives for Use in Hydraulic Test Analysis. Ground Water, Vol. 31, No. 5, pp. 814-822; published also as Pacific Northwest Laboratory, PNL-SA-21569 (1992).

Spane, F.A., Jr. 1993. Selected Hydraulic Test Analysis Techniques for Constant-Rate Discharge Tests. Pacific Northwest Laboratory, PNL-8539, Richland, Washington.

Wurstner S.K., P.D. Thorne, M.A. Chamness, M.D. Freshley, and M.D. Williams. 1995. Development of a Three-Dimensional Ground-Water Model of the Hanford Site Unconfined Aquifer System: FY 1995 status report. PNL-10886, Pacific Northwest Laboratory, Richland, Washington. 
V.G. Johnson

April 14, 2005

Page 5

Figure 1. S-SX Monitor Well Location Map

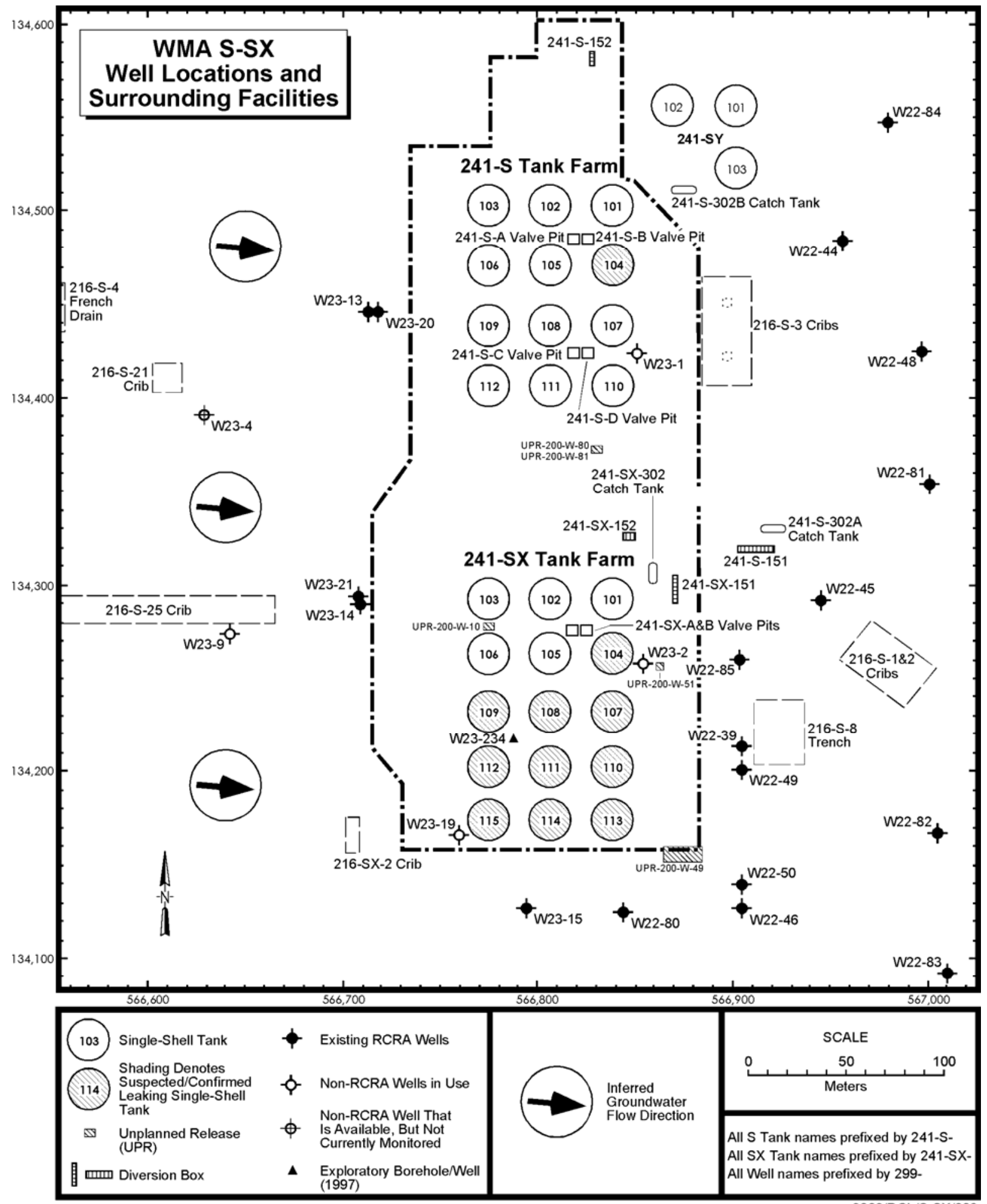

2002/DCL/S-SX/009 
V.G. Johnson

April 14, 2005

Page 6

Figure 2. Hydraulic Conductivity Distribution for S-SX Monitor Wells Based on Slug Test Results

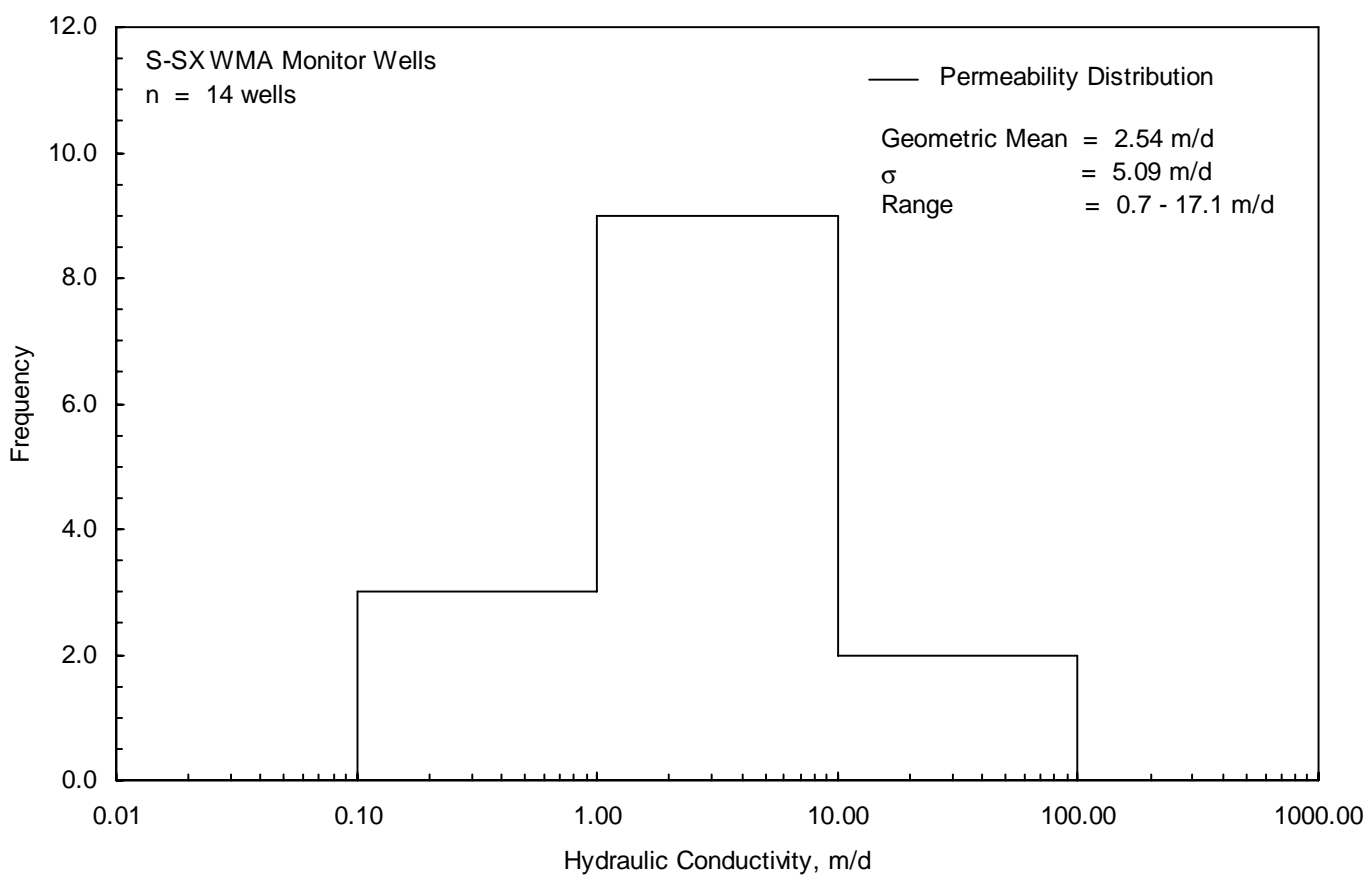

A.6 
V.G. Johnson

April 14, 2005

Page 7

Table 1. Hydraulic Property Summary for Slug- and Constant-Rate Pumping Tests Conducted During 1999 - 2001.

\begin{tabular}{|c|c|c|c|c|c|}
\hline \multirow[b]{2}{*}{$\begin{array}{c}\text { Waste } \\
\text { Management } \\
\text { Area }\end{array}$} & \multirow[b]{2}{*}{ Well } & Slug Test ${ }^{(\mathrm{a})}$ & \multicolumn{3}{|c|}{ "Constant-Rate Pumping Test } \\
\hline & & $\begin{array}{c}\text { Hydraulic } \\
\text { Conductivity, } \\
\mathrm{K}_{\mathrm{h}}, \mathrm{m} / \mathrm{d}\end{array}$ & $\begin{array}{c}\text { Hydraulic } \\
\text { Conductivity, } \\
\mathrm{K}_{\mathrm{h}}, \mathrm{m} / \mathrm{d}\end{array}$ & $\begin{array}{c}\text { Transmissivity, } \\
\mathrm{T}, \mathrm{m}^{2} / \mathrm{d}\end{array}$ & $\begin{array}{c}\text { Specific } \\
\text { Yield, } \\
\mathrm{S}_{\mathrm{y}}\end{array}$ \\
\hline \multirow{14}{*}{ S-SX } & $\begin{array}{l}\text { 299-W22-45* } \\
\text { heterogeneous }\end{array}$ & $\begin{array}{l}1.10-1.45 \\
\text { outer zone }\end{array}$ & $-^{-(b)}$ & - & 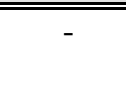 \\
\hline & \begin{tabular}{|l|} 
299-W22-46 \\
\end{tabular} & $2.43-3.37$ & - & - & - \\
\hline & \begin{tabular}{|l|}
$299-W 22-48$ \\
\end{tabular} & $1.42-1.86$ & 1.78 & 125 & 0.09 \\
\hline & 299-W22-49 & $6.04-7.97$ & 7.59 & 550 & 0.09 \\
\hline & \begin{tabular}{|l|}
$299-W 22-50$ \\
\end{tabular} & $4.24-5.70$ & 5.24 & 385 & 0.11 \\
\hline & 299-W22-80 & $(11.3-15.4)$ & (14.4) & (1035) & $(0.12)$ \\
\hline & \begin{tabular}{|l|} 
299-W22-81 \\
heterogeneous
\end{tabular} & $\begin{array}{c}(1.77-2.27) \\
\text { outer zone }\end{array}$ & (1.63) & $(112)$ & $(0.12)$ \\
\hline & \begin{tabular}{|l|} 
299-W22-82 \\
heterogeneous
\end{tabular} & $\begin{array}{c}(1.16-1.45) \\
\text { outer zone }\end{array}$ & - & - & - \\
\hline & \begin{tabular}{|l|} 
299-W22-83 \\
heterogeneous
\end{tabular} & $\begin{array}{c}(0.78-1.00) \\
\text { outer zone }\end{array}$ & - & - & - \\
\hline & \begin{tabular}{|l|} 
299-W22-84 \\
heterogeneous
\end{tabular} & $\begin{array}{c}(1.15-1.51) \\
\text { outer zone }\end{array}$ & - & - & - \\
\hline & \begin{tabular}{|l|} 
299-W22-85 \\
heterogeneous
\end{tabular} & $\begin{array}{c}\text { (5.69 - 7.73) } \\
\text { outer zone }\end{array}$ & - & - & - \\
\hline & \begin{tabular}{|l|} 
299-W23-15* \\
heterogeneous
\end{tabular} & $\begin{array}{l}0.56-0.78 \\
\text { outer zone }\end{array}$ & - & - & - \\
\hline & 299-W23-20 & $(16.9-17.2)$ & - & - & - \\
\hline & \begin{tabular}{|l|} 
299-W23-21 \\
heterogeneous
\end{tabular} & $\begin{array}{l}(0.59-0.75) \\
\text { outer zone }\end{array}$ & - & - & - \\
\hline \multicolumn{6}{|c|}{ 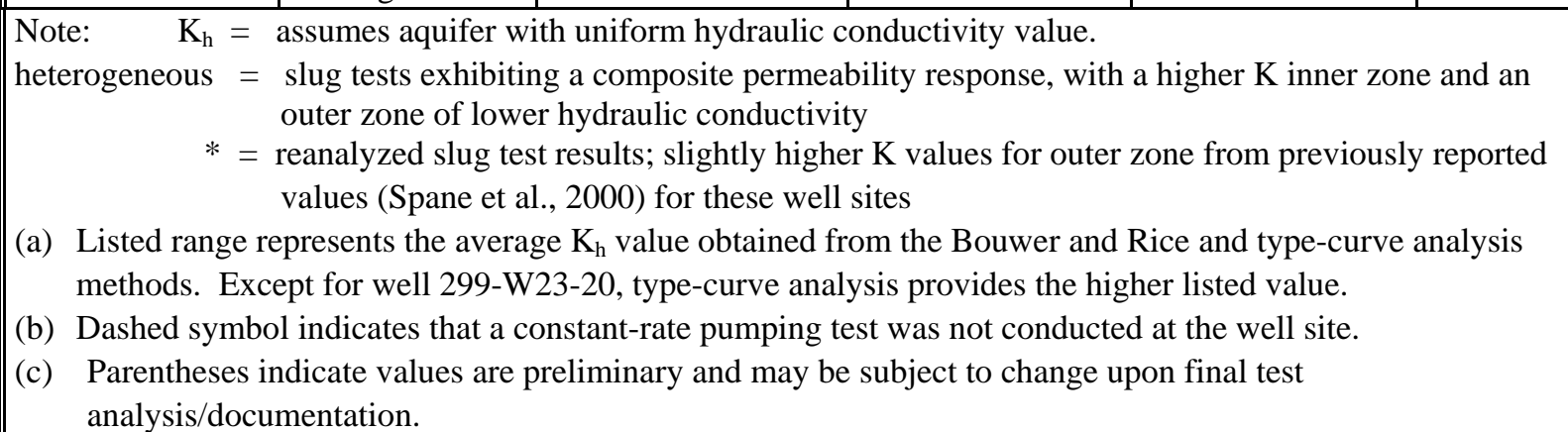 } \\
\hline
\end{tabular}




\section{Appendix B}

\section{Hydrologic Testing at Well 299-W23-19: Specific Conductance Results}




\section{Appendix B}

\section{Hydrologic Testing at Well 299-W23-19: Specific Conductance Results}

Specific conductance was monitored continuously with a flow through cell and a data logger during a step drawdown and constant discharge test conducted at well 299 W23-19 during the period of December 13 to 20, 2001. The test step drawdown was conducted first and covered a 250-minute period during which the well was pumped at 5 gallons per minute and then adjusted downward to about 1 gallon per minute. In general the specific conductance increased as the pumping rate decreased (Figure B.1).

The 72-hour constant discharge test was initiated three days following the step drawdown test. Specific conductance was recorded every minute for the first few hours and then at 10-minute intervals. Results are provided in the Table B.1. Initially the specific conductance was in the $1,500 \mu \mathrm{S} / \mathrm{cm}$ range. This was during an initial flow rate adjustment period when the rate was at about 1 gallon per minute. Then as the target flow rate of 3 gallons per minute was achieved, and thereafter, the specific conductance dropped to the 1,250 to $1,300 \mu \mathrm{S} / \mathrm{cm}$ range and remained at this level for the duration of the test.

Both of the above tests suggest that pumping rate has a significant impact on contaminant concentrations from this well. Also, the invariant specific conductance values over the 72-hour period, during which a volume of nearly 13,000 gallons was removed from the well, suggests contaminant concentrations are fairly uniform in the immediate vicinity of the well (radius of influence is estimated to be about $12 \mathrm{ft}$ (3.7 meters) assuming an effective porosity of 0.2). 


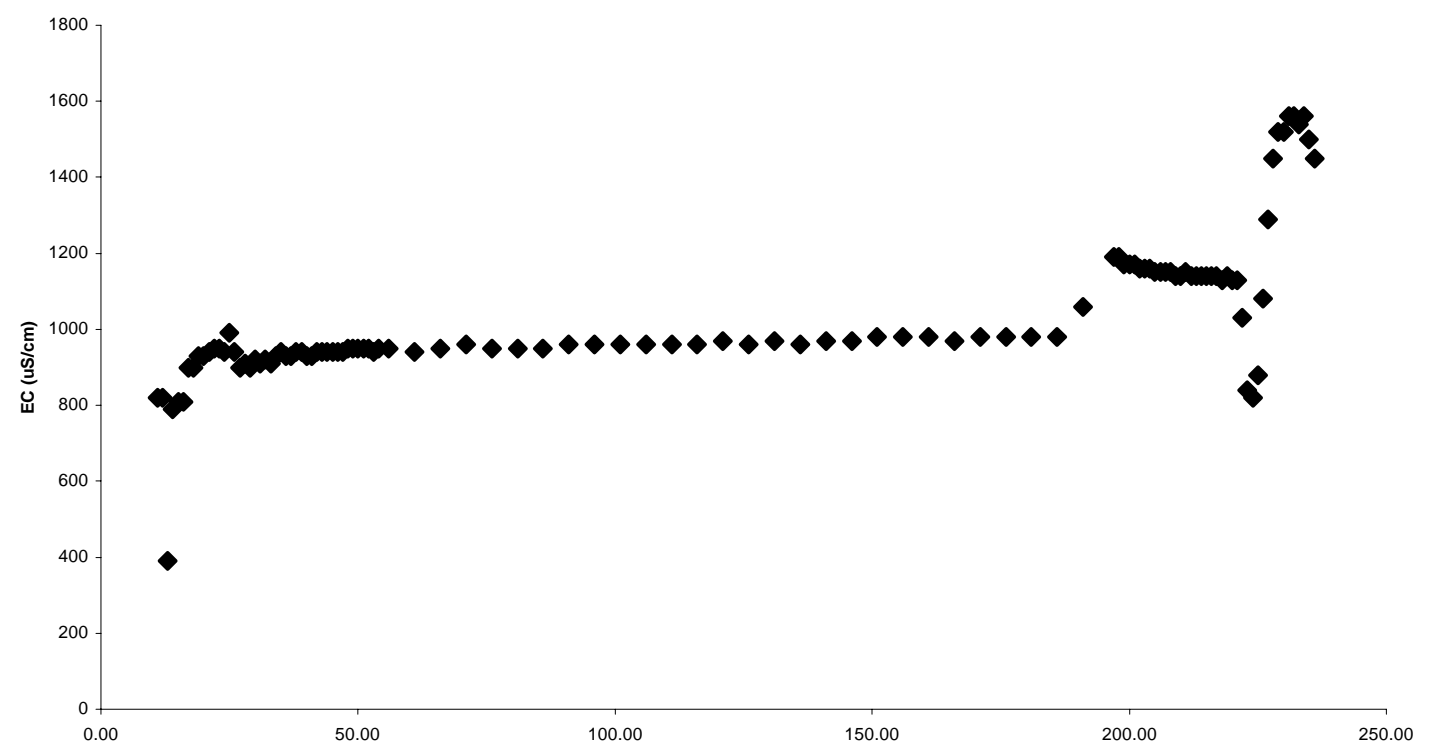

Figure B.1. Specific Conductance versus Time (minutes) at Well 299-W23-19 during a Step Drawdown Test (flow rate ranged from 1 to 5 gpm) 
Table B.1. Specific Conductance at Well 299-W23-19 during a 72-Hour Constant Discharge Test

\begin{tabular}{|c|c|c|c|c|c|}
\hline $\begin{array}{l}\text { Sample } \\
\text { Number }\end{array}$ & Date & Time & $\begin{array}{c}\text { Conductivity } \\
(\mu \mathrm{S} / \mathrm{cm})\end{array}$ & $\begin{array}{c}\text { Temperature } \\
\left({ }^{\circ} \mathrm{C}\right)\end{array}$ & Notes \\
\hline 1 & $12 / 17 / 2001$ & 08:52:00AM & 0.04 & 15.8 & \\
\hline 2 & $12 / 17 / 2001$ & 08:53:00AM & 0.03 & 16.4 & \\
\hline 3 & $12 / 17 / 2001$ & 08:54:00AM & 0.03 & 16.8 & \\
\hline 4 & $12 / 17 / 2001$ & 08:55:00AM & 1,258 & 10 & Pump started \\
\hline 5 & $12 / 17 / 2001$ & 08:56:00AM & 1,518 & 7.3 & \\
\hline 6 & $12 / 17 / 2001$ & 08:57:00AM & 1,538 & 7.1 & Flow was set too low ( 1gpm) \\
\hline 7 & $12 / 17 / 2001$ & 08:58:00AM & 1,552 & 7 & \\
\hline 8 & $12 / 17 / 2001$ & 08:59:00AM & 1,556 & 7.1 & \\
\hline 9 & $12 / 17 / 2001$ & 09:00:00AM & 1,557 & 7.1 & \\
\hline 10 & $12 / 17 / 2001$ & 09:01:00AM & 1,562 & 7.2 & \\
\hline 11 & $12 / 17 / 2001$ & 09:02:00AM & 1,568 & 7.3 & \\
\hline 12 & $12 / 17 / 2001$ & 09:03:00AM & 1,570 & 7.6 & \\
\hline 13 & $12 / 17 / 2001$ & 09:04:00AM & 1,572 & 8.1 & \\
\hline 14 & $12 / 17 / 2001$ & 09:05:00AM & 1,570 & 8.8 & \\
\hline 15 & $12 / 17 / 2001$ & 09:06:00AM & 1,566 & 9.5 & \\
\hline 16 & $12 / 17 / 2001$ & 09:07:00AM & 1,564 & 10.3 & \\
\hline 17 & $12 / 17 / 2001$ & 09:08:00AM & 1,557 & 11.2 & \\
\hline 18 & $12 / 17 / 2001$ & 09:09:00AM & 1,554 & 11.9 & \\
\hline 19 & $12 / 17 / 2001$ & 09:10:00AM & 1,549 & 12.6 & \\
\hline 20 & $12 / 17 / 2001$ & 09:11:00AM & 1,541 & 13.2 & \\
\hline 21 & $12 / 17 / 2001$ & 09:12:00AM & 1,533 & 13.7 & \\
\hline 22 & $12 / 17 / 2001$ & 09:13:00AM & 1,529 & 14.1 & \\
\hline 23 & $12 / 17 / 2001$ & 09:14:00AM & 1,521 & 14.4 & \\
\hline 24 & $12 / 17 / 2001$ & 09:15:00AM & 1,514 & 14.5 & \\
\hline 25 & $12 / 17 / 2001$ & 09:16:00AM & 1,505 & 14.6 & \\
\hline 26 & $12 / 17 / 2001$ & 09:17:00AM & 1,501 & 14.6 & \\
\hline 27 & $12 / 17 / 2001$ & 09:18:00AM & 1,497 & 14.5 & \\
\hline 28 & $12 / 17 / 2001$ & 09:19:00AM & 1,487 & 14.4 & \\
\hline 29 & $12 / 17 / 2001$ & 09:20:00AM & 1,475 & 14.2 & \\
\hline 30 & $12 / 17 / 2001$ & 09:21:00AM & 1,465 & 14.2 & \\
\hline 31 & $12 / 17 / 2001$ & 09:22:00AM & 1,438 & 14.1 & \\
\hline 32 & $12 / 17 / 2001$ & 09:23:00AM & 1,414 & 14 & \\
\hline 33 & $12 / 17 / 2001$ & 09:24:00AM & 1,374 & 13.8 & \\
\hline 34 & $12 / 17 / 2001$ & 09:25:00AM & 1,329 & 13.6 & \\
\hline 35 & $12 / 17 / 2001$ & 09:26:00AM & 1,293 & 13.5 & \\
\hline 36 & $12 / 17 / 2001$ & 09:27:00AM & 1,257 & 13.4 & \\
\hline 37 & $12 / 17 / 2001$ & 09:28:00AM & 1,144 & 13.4 & \\
\hline 38 & $12 / 17 / 2001$ & 09:29:00AM & 999 & 13.4 & \\
\hline 39 & $12 / 17 / 2001$ & 09:30:00AM & 908 & 13.4 & $\begin{array}{l}\text { Flow set back to } 3 \mathrm{gpm} \text { (took } \\
\text { awhile for DynCorp crew to get } \\
\text { system adjusted }\end{array}$ \\
\hline
\end{tabular}




\begin{tabular}{|c|c|c|c|c|c|}
\hline $\begin{array}{l}\text { Sample } \\
\text { Number } \\
\end{array}$ & Date & Time & $\begin{array}{c}\text { Conductivity } \\
(\mu \mathrm{S} / \mathrm{cm})\end{array}$ & $\begin{array}{c}\text { Temperature } \\
\left({ }^{\circ} \mathrm{C}\right) \\
\end{array}$ & Notes \\
\hline 40 & $12 / 17 / 2001$ & 09:31:00AM & 904 & 13.5 & \\
\hline 41 & $12 / 17 / 2001$ & 09:32:00AM & 1,019 & 14.3 & \\
\hline 42 & $12 / 17 / 2001$ & 09:33:00AM & 1,075 & 15.5 & \\
\hline 43 & $12 / 17 / 2001$ & 09:34:00AM & 1,337 & 16.8 & \\
\hline 44 & $12 / 17 / 2001$ & 09:35:00AM & 1,471 & 17.8 & \\
\hline 45 & $12 / 17 / 2001$ & 09:36:00AM & 1,245 & 18.9 & \\
\hline 46 & $12 / 17 / 2001$ & 09:37:00AM & 1,231 & 18.9 & \\
\hline 47 & $12 / 17 / 2001$ & 09:38:00AM & 1,267 & 18.6 & \\
\hline 48 & $12 / 17 / 2001$ & 09:39:00AM & 1,319 & 18.4 & \\
\hline 49 & $12 / 17 / 2001$ & 09:40:00AM & 1,293 & 19 & \\
\hline 50 & $12 / 17 / 2001$ & 09:41:00AM & 1,338 & 19 & \\
\hline 51 & $12 / 17 / 2001$ & 09:42:00AM & 1,347 & 18.9 & \\
\hline 52 & $12 / 17 / 2001$ & 09:43:00AM & 1,313 & 18.9 & \\
\hline 53 & $12 / 17 / 2001$ & 09:44:00AM & 1,312 & 18.9 & \\
\hline 54 & $12 / 17 / 2001$ & 09:45:00AM & 1,327 & 18.9 & \\
\hline 55 & $12 / 17 / 2001$ & 09:46:00AM & 1,337 & 18.8 & \\
\hline 56 & $12 / 17 / 2001$ & 09:47:00AM & 1,314 & 18.8 & \\
\hline 57 & $12 / 17 / 2001$ & 09:48:00AM & 1,319 & 18.7 & \\
\hline 58 & $12 / 17 / 2001$ & 09:49:00AM & 1,320 & 18.7 & \\
\hline 59 & $12 / 17 / 2001$ & 09:50:00AM & 1,300 & 18.7 & \\
\hline 60 & $12 / 17 / 2001$ & 09:51:00AM & 1,309 & 18.6 & \\
\hline 61 & $12 / 17 / 2001$ & 09:52:00AM & 1,322 & 18.5 & \\
\hline 62 & $12 / 17 / 2001$ & 09:53:00AM & 1,355 & 18.5 & \\
\hline 63 & $12 / 17 / 2001$ & 09:54:00AM & 1,335 & 18.5 & \\
\hline 64 & $12 / 17 / 2001$ & 09:55:00AM & 1,315 & 18.5 & \\
\hline 65 & $12 / 17 / 2001$ & 09:56:00AM & 1,314 & 18.5 & \\
\hline 66 & $12 / 17 / 2001$ & 09:57:00AM & 1,301 & 18.5 & \\
\hline 67 & $12 / 17 / 2001$ & 09:58:00AM & 1,286 & 18.5 & \\
\hline 68 & $12 / 17 / 2001$ & 09:59:00AM & 1,273 & 18.5 & \\
\hline 69 & $12 / 17 / 2001$ & 10:00:00AM & 1,261 & 18.4 & \\
\hline 70 & $12 / 17 / 2001$ & 10:01:00AM & 1,260 & 18.3 & \\
\hline 71 & $12 / 17 / 2001$ & 10:02:00AM & 1,253 & 18.3 & \\
\hline 72 & $12 / 17 / 2001$ & 10:03:00AM & 1,248 & 18.1 & \\
\hline 73 & $12 / 17 / 2001$ & 10:04:00AM & 1,245 & 18 & \\
\hline 74 & $12 / 17 / 2001$ & 10:05:00AM & 1,239 & 18 & \\
\hline 75 & $12 / 17 / 2001$ & 10:06:00AM & 1,237 & 18 & \\
\hline 76 & $12 / 17 / 2001$ & 10:07:00AM & 1,235 & 17.9 & \\
\hline 77 & $12 / 17 / 2001$ & 10:08:00AM & 1,239 & 17.9 & \\
\hline 78 & $12 / 17 / 2001$ & 10:09:00AM & 1,230 & 17.9 & \\
\hline 79 & $12 / 17 / 2001$ & 10:10:00AM & 1,235 & 17.9 & \\
\hline 80 & $12 / 17 / 2001$ & 10:15:00AM & 1,248 & 17.9 & \\
\hline 81 & $12 / 17 / 2001$ & 10:20:00AM & 1,241 & 18.2 & \\
\hline 82 & $12 / 17 / 2001$ & 10:25:00AM & 1,246 & 18.3 & \\
\hline
\end{tabular}

\section{B. 4}




\begin{tabular}{|c|c|c|c|c|c|}
\hline $\begin{array}{c}\text { Sample } \\
\text { Number } \\
\end{array}$ & Date & Time & $\begin{array}{c}\text { Conductivity } \\
(\mu \mathrm{S} / \mathrm{cm})\end{array}$ & $\begin{array}{c}\text { Temperature } \\
\left({ }^{\circ} \mathrm{C}\right) \\
\end{array}$ & Notes \\
\hline 83 & $12 / 17 / 2001$ & 10:30:00AM & 1,245 & 18.1 & \\
\hline 84 & $12 / 17 / 2001$ & 10:35:00AM & 1,257 & 18.2 & \\
\hline 85 & $12 / 17 / 2001$ & 10:40:00AM & 1,248 & 18.3 & \\
\hline 86 & $12 / 17 / 2001$ & 10:45:00AM & 1,241 & 18.2 & \\
\hline 87 & $12 / 17 / 2001$ & 10:50:00AM & 1,245 & 17.9 & \\
\hline 88 & $12 / 17 / 2001$ & 10:55:00AM & 1,244 & 18 & \\
\hline 89 & $12 / 17 / 2001$ & 11:00:00AM & 1,249 & 18 & \\
\hline 90 & $12 / 17 / 2001$ & 11:05:00AM & 1,248 & 17.4 & \\
\hline 91 & $12 / 17 / 2001$ & 11:10:00AM & 1,245 & 16.7 & \\
\hline 92 & $12 / 17 / 2001$ & 11:15:00AM & 1,242 & 16.5 & \\
\hline 93 & $12 / 17 / 2001$ & 11:20:00AM & 1,246 & 16.7 & \\
\hline 94 & $12 / 17 / 2001$ & 11:25:00AM & 1,239 & 16.7 & \\
\hline 95 & $12 / 17 / 2001$ & 11:30:00AM & 1,244 & 16.7 & \\
\hline 96 & $12 / 17 / 2001$ & 11:35:00AM & 1,239 & 16.6 & \\
\hline 97 & $12 / 17 / 2001$ & 11:40:00AM & 1,247 & 17 & \\
\hline 98 & $12 / 17 / 2001$ & 11:45:00AM & 1,236 & 17.1 & \\
\hline 99 & $12 / 17 / 2001$ & 11:50:00AM & 1,242 & 16.9 & \\
\hline 100 & $12 / 17 / 2001$ & 11:55:00AM & 1,247 & 16.6 & \\
\hline 101 & $12 / 17 / 2001$ & 12:00:00PM & 1,242 & 16.6 & \\
\hline 102 & $12 / 17 / 2001$ & 12:05:00PM & 1,230 & 16.9 & \\
\hline 103 & $12 / 17 / 2001$ & 12:10:00PM & 1,234 & 17 & \\
\hline 104 & $12 / 17 / 2001$ & 12:15:00PM & 1,233 & 17.1 & \\
\hline 105 & $12 / 17 / 2001$ & 12:20:00PM & 1,231 & 17 & \\
\hline 106 & $12 / 17 / 2001$ & 12:25:00PM & 1,239 & 17.1 & \\
\hline 107 & $12 / 17 / 2001$ & 12:30:00PM & 1,226 & 17.3 & \\
\hline 108 & $12 / 17 / 2001$ & 12:35:00PM & 1,228 & 17 & \\
\hline 109 & $12 / 17 / 2001$ & 12:40:00PM & 1,226 & 16.9 & \\
\hline 110 & $12 / 17 / 2001$ & 12:45:00PM & 1,228 & 17.2 & \\
\hline 111 & $12 / 17 / 2001$ & 12:50:00PM & 1,233 & 17.3 & \\
\hline 112 & $12 / 17 / 2001$ & 12:55:00PM & 1,232 & 17.2 & \\
\hline 113 & $12 / 17 / 2001$ & 01:00:00PM & 1,238 & 17.2 & \\
\hline 114 & $12 / 17 / 2001$ & 01:05:00PM & 1,236 & 17.1 & \\
\hline 115 & $12 / 17 / 2001$ & 01:10:00PM & 1,232 & 17.1 & \\
\hline 116 & $12 / 17 / 2001$ & 01:15:00PM & 1,230 & 17.1 & \\
\hline 117 & $12 / 17 / 2001$ & 01:20:00PM & 1,228 & 17.1 & \\
\hline 118 & $12 / 17 / 2001$ & 01:25:00PM & 1,238 & 17.1 & \\
\hline 119 & $12 / 17 / 2001$ & 01:30:00PM & 1,242 & 17.2 & \\
\hline 120 & $12 / 17 / 2001$ & 01:35:00PM & 1,225 & 17.2 & \\
\hline 121 & $12 / 17 / 2001$ & 01:40:00PM & 1,234 & 17.3 & \\
\hline 122 & $12 / 17 / 2001$ & 01:45:00PM & 1,230 & 17.4 & \\
\hline 123 & $12 / 17 / 2001$ & 01:50:00PM & 1,235 & 17.3 & \\
\hline 124 & $12 / 17 / 2001$ & 01:55:00PM & 1,224 & 17.4 & \\
\hline 125 & $12 / 17 / 2001$ & 02:00:00PM & 1,228 & 17.5 & \\
\hline
\end{tabular}

B. 5 


\begin{tabular}{|c|c|c|c|c|c|}
\hline $\begin{array}{c}\text { Sample } \\
\text { Number } \\
\end{array}$ & Date & Time & $\begin{array}{c}\text { Conductivity } \\
(\mu \mathrm{S} / \mathrm{cm})\end{array}$ & $\begin{array}{c}\text { Temperature } \\
\left({ }^{\circ} \mathrm{C}\right) \\
\end{array}$ & Notes \\
\hline 126 & $12 / 17 / 2001$ & 02:05:00PM & 1,233 & 17.5 & \\
\hline 127 & $12 / 17 / 2001$ & 02:10:00PM & 1,226 & 17.5 & \\
\hline 128 & $12 / 17 / 2001$ & 02:15:00PM & 1,231 & 17.4 & \\
\hline 129 & $12 / 17 / 2001$ & 02:20:00PM & 1,234 & 17.3 & \\
\hline 130 & $12 / 17 / 2001$ & 02:25:00PM & 1,231 & 17.2 & \\
\hline 131 & $12 / 17 / 2001$ & 02:30:00PM & 1,235 & 17.4 & \\
\hline 132 & $12 / 17 / 2001$ & 02:35:00PM & 1,226 & 17.6 & \\
\hline 133 & $12 / 17 / 2001$ & 02:40:00PM & 1,232 & 17.6 & \\
\hline 134 & $12 / 17 / 2001$ & 02:45:00PM & 1,236 & 17.7 & \\
\hline 135 & $12 / 17 / 2001$ & 02:50:00PM & 1,227 & 17.7 & \\
\hline 136 & $12 / 17 / 2001$ & 02:55:00PM & 1,225 & 17.7 & \\
\hline 137 & $12 / 17 / 2001$ & 03:00:00PM & 1,227 & 17.5 & \\
\hline 138 & $12 / 17 / 2001$ & 03:05:00PM & 1,235 & 17.7 & \\
\hline 139 & $12 / 17 / 2001$ & 03:10:00PM & 1,228 & 17.6 & \\
\hline 140 & $12 / 17 / 2001$ & 03:15:00PM & 1,231 & 17.6 & \\
\hline 141 & $12 / 17 / 2001$ & 03:20:00PM & 1,237 & 17.5 & \\
\hline 142 & $12 / 17 / 2001$ & 03:25:00PM & 1,222 & 17.3 & \\
\hline 143 & $12 / 17 / 2001$ & 03:30:00PM & 1,233 & 17.3 & \\
\hline 144 & $12 / 17 / 2001$ & 03:35:00PM & 1,233 & 17.2 & \\
\hline 145 & $12 / 17 / 2001$ & 03:40:00PM & 1,234 & 17.2 & \\
\hline 146 & $12 / 17 / 2001$ & 03:45:00PM & 1,224 & 17.1 & \\
\hline 147 & $12 / 17 / 2001$ & 03:50:00PM & 1,231 & 17 & \\
\hline 148 & $12 / 17 / 2001$ & 03:55:00PM & 1,234 & 17 & \\
\hline 149 & $12 / 17 / 2001$ & 04:00:00PM & 1,229 & 17.1 & \\
\hline 150 & $12 / 17 / 2001$ & 04:05:00PM & 1,233 & 17 & \\
\hline 151 & $12 / 17 / 2001$ & 04:10:00PM & 1,235 & 16.8 & \\
\hline 152 & $12 / 17 / 2001$ & 04:15:00PM & 1,224 & 16.9 & \\
\hline 153 & $12 / 17 / 2001$ & 04:20:00PM & 1,230 & 16.8 & \\
\hline 154 & $12 / 17 / 2001$ & 04:25:00PM & 1,231 & 16.8 & \\
\hline 155 & $12 / 17 / 2001$ & 04:30:00PM & 1,227 & 17 & \\
\hline 156 & $12 / 17 / 2001$ & 04:35:00PM & 1,232 & 16.8 & \\
\hline 157 & $12 / 17 / 2001$ & 04:40:00PM & 1,243 & 16.8 & \\
\hline 158 & $12 / 17 / 2001$ & 04:45:00PM & 1,233 & 16.8 & \\
\hline 159 & $12 / 17 / 2001$ & 04:50:00PM & 1,238 & 16.7 & \\
\hline 160 & $12 / 17 / 2001$ & 04:55:00PM & 1,234 & 16.8 & \\
\hline 161 & $12 / 17 / 2001$ & 05:00:00PM & 1,241 & 16.7 & \\
\hline 162 & $12 / 17 / 2001$ & 05:05:00PM & 1,226 & 16.9 & \\
\hline 163 & $12 / 17 / 2001$ & 05:10:00PM & 1,244 & 16.6 & \\
\hline 164 & $12 / 17 / 2001$ & 05:15:00PM & 1,233 & 16.6 & \\
\hline 165 & $12 / 17 / 2001$ & 05:20:00PM & 1,243 & 16.7 & \\
\hline 166 & $12 / 17 / 2001$ & 05:25:00PM & 1,230 & 16.4 & \\
\hline 167 & $12 / 17 / 2001$ & 05:30:00PM & 1,236 & 16.3 & \\
\hline 168 & $12 / 17 / 2001$ & 05:35:00PM & 1,241 & 16.3 & \\
\hline
\end{tabular}

B. 6 


\begin{tabular}{|c|c|c|c|c|c|}
\hline $\begin{array}{c}\text { Sample } \\
\text { Number } \\
\end{array}$ & Date & Time & $\begin{array}{c}\text { Conductivity } \\
(\mu \mathrm{S} / \mathrm{cm})\end{array}$ & $\begin{array}{c}\text { Temperature } \\
\left({ }^{\circ} \mathrm{C}\right) \\
\end{array}$ & Notes \\
\hline 169 & $12 / 17 / 2001$ & 05:40:00PM & 1,233 & 16.4 & \\
\hline 170 & $12 / 17 / 2001$ & 05:45:00PM & 1,242 & 16.5 & \\
\hline 171 & $12 / 17 / 2001$ & 05:50:00PM & 1,232 & 16.4 & \\
\hline 172 & $12 / 17 / 2001$ & 05:55:00PM & 1,239 & 16.6 & \\
\hline 173 & $12 / 17 / 2001$ & 06:00:00PM & 1,231 & 16.7 & \\
\hline 174 & $12 / 17 / 2001$ & 06:05:00PM & 1,236 & 16.2 & \\
\hline 175 & $12 / 17 / 2001$ & 06:10:00PM & 1,236 & 16.1 & \\
\hline 176 & $12 / 17 / 2001$ & 06:15:00PM & 1,232 & 15.7 & \\
\hline 177 & $12 / 17 / 2001$ & 06:20:00PM & 1,241 & 15.4 & \\
\hline 178 & $12 / 17 / 2001$ & 06:25:00PM & 1,238 & 15.7 & \\
\hline 179 & $12 / 17 / 2001$ & 06:30:00PM & 1,241 & 16.2 & \\
\hline 180 & $12 / 17 / 2001$ & 06:35:00PM & 1,238 & 16.4 & \\
\hline 181 & $12 / 17 / 2001$ & 06:40:00PM & 1,234 & 16.2 & \\
\hline 182 & $12 / 17 / 2001$ & 06:45:00PM & 1,231 & 16.1 & \\
\hline 183 & $12 / 17 / 2001$ & 06:50:00PM & 1,240 & 16.2 & \\
\hline 184 & $12 / 17 / 2001$ & 06:55:00PM & 1,233 & 16.2 & \\
\hline 185 & $12 / 17 / 2001$ & 07:00:00PM & 1,243 & 16.1 & \\
\hline 186 & $12 / 17 / 2001$ & 07:05:00PM & 1,236 & 16 & \\
\hline 187 & $12 / 17 / 2001$ & 07:10:00PM & 1,239 & 16 & \\
\hline 188 & $12 / 17 / 2001$ & 07:15:00PM & 1,237 & 15.9 & \\
\hline 189 & $12 / 17 / 2001$ & 07:20:00PM & 1,241 & 15.9 & \\
\hline 190 & $12 / 17 / 2001$ & 07:25:00PM & 1,232 & 16 & \\
\hline 191 & $12 / 17 / 2001$ & 07:30:00PM & 1,234 & 15.9 & \\
\hline 192 & $12 / 17 / 2001$ & 07:35:00PM & 1,241 & 15.5 & \\
\hline 193 & $12 / 17 / 2001$ & 07:40:00PM & 1,242 & 15.5 & \\
\hline 194 & $12 / 17 / 2001$ & 07:45:00PM & 1,239 & 15.5 & \\
\hline 195 & $12 / 17 / 2001$ & 07:50:00PM & 1,238 & 15.8 & \\
\hline 196 & $12 / 17 / 2001$ & 07:55:00PM & 1,242 & 15.9 & \\
\hline 197 & $12 / 17 / 2001$ & 08:00:00PM & 1,242 & 16 & \\
\hline 198 & $12 / 17 / 2001$ & 08:05:00PM & 1,235 & 16 & \\
\hline 199 & $12 / 17 / 2001$ & 08:10:00PM & 1,236 & 15.9 & \\
\hline 200 & $12 / 17 / 2001$ & 08:15:00PM & 1,239 & 15.8 & \\
\hline 201 & $12 / 17 / 2001$ & 08:20:00PM & 1,243 & 15.9 & \\
\hline 202 & $12 / 17 / 2001$ & 08:25:00PM & 1,233 & 16.2 & \\
\hline 203 & $12 / 17 / 2001$ & 08:30:00PM & 1,244 & 16.3 & \\
\hline 204 & $12 / 17 / 2001$ & 08:35:00PM & 1,234 & 16 & \\
\hline 205 & $12 / 17 / 2001$ & 08:40:00PM & 1,248 & 15.8 & \\
\hline 206 & $12 / 17 / 2001$ & 08:45:00PM & 1,246 & 16.1 & \\
\hline 207 & $12 / 17 / 2001$ & 08:50:00PM & 1,240 & 16 & \\
\hline 208 & $12 / 17 / 2001$ & 08:55:00PM & 1,233 & 16.1 & \\
\hline 209 & $12 / 17 / 2001$ & 09:00:00PM & 1,233 & 16.1 & \\
\hline 210 & $12 / 17 / 2001$ & 09:05:00PM & 1,242 & 16.3 & \\
\hline 211 & $12 / 17 / 2001$ & 09:10:00PM & 1,236 & 16.2 & \\
\hline
\end{tabular}

B. 7 


\begin{tabular}{|c|c|c|c|c|c|}
\hline $\begin{array}{l}\text { Sample } \\
\text { Number } \\
\end{array}$ & Date & Time & $\begin{array}{c}\text { Conductivity } \\
(\mu \mathrm{S} / \mathrm{cm})\end{array}$ & $\begin{array}{c}\text { Temperature } \\
\left({ }^{\circ} \mathrm{C}\right) \\
\end{array}$ & Notes \\
\hline 212 & $12 / 17 / 2001$ & 09:15:00PM & 1,241 & 16.2 & \\
\hline 213 & $12 / 17 / 2001$ & 09:20:00PM & 1,241 & 15.9 & \\
\hline 214 & $12 / 17 / 2001$ & 09:25:00PM & 1,240 & 15.7 & \\
\hline 215 & $12 / 17 / 2001$ & 09:30:00PM & 1,247 & 15.8 & \\
\hline 216 & $12 / 17 / 2001$ & 09:35:00PM & 1,242 & 16.1 & \\
\hline 217 & $12 / 17 / 2001$ & 09:40:00PM & 1,246 & 16.1 & \\
\hline 218 & $12 / 17 / 2001$ & 09:45:00PM & 1,234 & 15.9 & \\
\hline 219 & $12 / 17 / 2001$ & 09:50:00PM & 1,246 & 15.8 & \\
\hline 220 & $12 / 17 / 2001$ & 09:55:00PM & 1,237 & 15.8 & \\
\hline 221 & $12 / 17 / 2001$ & 10:00:00PM & 1,242 & 15.7 & \\
\hline 222 & $12 / 17 / 2001$ & 10:05:00PM & 1,238 & 15.6 & \\
\hline 223 & $12 / 17 / 2001$ & 10:10:00PM & 1,241 & 15.9 & \\
\hline 224 & $12 / 17 / 2001$ & 10:15:00PM & 1,237 & 15.8 & \\
\hline 225 & $12 / 17 / 2001$ & 10:20:00PM & 1,240 & 15.8 & \\
\hline 226 & $12 / 17 / 2001$ & 10:25:00PM & 1,244 & 15.5 & \\
\hline 227 & $12 / 17 / 2001$ & 10:30:00PM & 1,246 & 15.4 & \\
\hline 228 & $12 / 17 / 2001$ & 10:35:00PM & 1,242 & 15.6 & \\
\hline 229 & $12 / 17 / 2001$ & 10:40:00PM & 1,244 & 15.6 & \\
\hline 230 & $12 / 17 / 2001$ & 10:45:00PM & 1,235 & 15.7 & \\
\hline 231 & $12 / 17 / 2001$ & 10:50:00PM & 1,249 & 15.7 & \\
\hline 232 & $12 / 17 / 2001$ & 10:55:00PM & 1,240 & 15.8 & \\
\hline 233 & $12 / 17 / 2001$ & 11:00:00PM & 1,245 & 15.8 & \\
\hline 234 & $12 / 17 / 2001$ & 11:05:00PM & 1,234 & 15.7 & \\
\hline 235 & $12 / 17 / 2001$ & 11:10:00PM & 1,238 & 15.3 & \\
\hline 236 & $12 / 17 / 2001$ & 11:15:00PM & 1,245 & 15.4 & \\
\hline 237 & $12 / 17 / 2001$ & 11:20:00PM & 1,245 & 15.4 & \\
\hline 238 & $12 / 17 / 2001$ & 11:25:00PM & 1,247 & 15.4 & \\
\hline 239 & $12 / 17 / 2001$ & 11:30:00PM & 1,242 & 15.4 & \\
\hline 240 & $12 / 17 / 2001$ & 11:35:00PM & 1,242 & 15.4 & \\
\hline 241 & $12 / 17 / 2001$ & 11:40:00PM & 1,241 & 15.4 & \\
\hline 242 & $12 / 17 / 2001$ & 11:45:00PM & 1,245 & 15.5 & \\
\hline 243 & $12 / 17 / 2001$ & 11:50:00PM & 1,245 & 15.5 & \\
\hline 244 & $12 / 17 / 2001$ & 11:55:00PM & 1,244 & 15.6 & \\
\hline 245 & $12 / 17 / 2001$ & 12:00:00AM & 1,236 & 15.7 & \\
\hline 246 & $12 / 18 / 2001$ & 12:05:00AM & 1,242 & 15.7 & \\
\hline 247 & $12 / 18 / 2001$ & 12:10:00AM & 1,244 & 15.6 & \\
\hline 248 & $12 / 18 / 2001$ & 12:15:00AM & 1,241 & 15.5 & \\
\hline 249 & $12 / 18 / 2001$ & 12:20:00AM & 1,240 & 16 & \\
\hline 250 & $12 / 18 / 2001$ & 12:25:00AM & 1,244 & 16.1 & \\
\hline 251 & $12 / 18 / 2001$ & 12:30:00AM & 1,242 & 16.1 & \\
\hline 252 & $12 / 18 / 2001$ & 12:35:00AM & 1,245 & 16.4 & \\
\hline 253 & $12 / 18 / 2001$ & 12:40:00AM & 1,241 & 16.5 & \\
\hline 254 & $12 / 18 / 2001$ & 12:45:00AM & 1,239 & 16.2 & \\
\hline
\end{tabular}

\section{B. 8}




\begin{tabular}{|c|c|c|c|c|c|}
\hline $\begin{array}{l}\text { Sample } \\
\text { Number } \\
\end{array}$ & Date & Time & $\begin{array}{c}\text { Conductivity } \\
(\mu \mathrm{S} / \mathrm{cm})\end{array}$ & $\begin{array}{c}\text { Temperature } \\
\left({ }^{\circ} \mathrm{C}\right) \\
\end{array}$ & Notes \\
\hline 255 & $12 / 18 / 2001$ & 12:50:00AM & 1,233 & 16 & \\
\hline 256 & $12 / 18 / 2001$ & 12:55:00AM & 1,241 & 16 & \\
\hline 257 & $12 / 18 / 2001$ & 01:00:00AM & 1,239 & 16.1 & \\
\hline 258 & $12 / 18 / 2001$ & 01:05:00AM & 1,237 & 16.3 & \\
\hline 259 & $12 / 18 / 2001$ & 01:10:00AM & 1,233 & 16.4 & \\
\hline 260 & $12 / 18 / 2001$ & 01:15:00AM & 1,246 & 16.4 & \\
\hline 261 & $12 / 18 / 2001$ & 01:20:00AM & 1,244 & 16.3 & \\
\hline 262 & $12 / 18 / 2001$ & 01:25:00AM & 1,239 & 16.3 & \\
\hline 263 & $12 / 18 / 2001$ & 01:30:00AM & 1,240 & 16.5 & \\
\hline 264 & $12 / 18 / 2001$ & 01:35:00AM & 1,238 & 16.6 & \\
\hline 265 & $12 / 18 / 2001$ & 01:40:00AM & 1,236 & 16.5 & \\
\hline 266 & $12 / 18 / 2001$ & 01:45:00AM & 1,240 & 16.1 & \\
\hline 267 & $12 / 18 / 2001$ & 01:50:00AM & 1,236 & 16.2 & \\
\hline 268 & $12 / 18 / 2001$ & 01:55:00AM & 1,234 & 16.5 & \\
\hline 269 & $12 / 18 / 2001$ & 02:00:00AM & 1,228 & 14.5 & \\
\hline 270 & $12 / 18 / 2001$ & 02:05:00AM & 1,239 & 16.1 & \\
\hline 271 & $12 / 18 / 2001$ & 02:10:00AM & 1,237 & 16.1 & \\
\hline 272 & $12 / 18 / 2001$ & 02:15:00AM & 1,206 & 15.9 & \\
\hline 273 & $12 / 18 / 2001$ & 02:20:00AM & 1,256 & 16.1 & \\
\hline 274 & $12 / 18 / 2001$ & 02:25:00AM & 1,269 & 15.8 & \\
\hline 275 & $12 / 18 / 2001$ & 02:30:00AM & 1,249 & 15.8 & \\
\hline 276 & $12 / 18 / 2001$ & 02:35:00AM & 1,245 & 15.8 & \\
\hline 277 & $12 / 18 / 2001$ & 02:40:00AM & 1,246 & 16.1 & \\
\hline 278 & $12 / 18 / 2001$ & 02:45:00AM & 1,330 & 15.9 & \\
\hline 279 & $12 / 18 / 2001$ & 02:50:00AM & 1,249 & 15.8 & \\
\hline 280 & $12 / 18 / 2001$ & 02:55:00AM & 1,196 & 15.7 & \\
\hline 281 & $12 / 18 / 2001$ & 03:00:00AM & 1,194 & 15.9 & \\
\hline 282 & $12 / 18 / 2001$ & 03:05:00AM & 1,240 & 16.1 & \\
\hline 283 & $12 / 18 / 2001$ & 03:10:00AM & 1,349 & 16 & \\
\hline 284 & $12 / 18 / 2001$ & 03:15:00AM & 1,244 & 15.8 & \\
\hline 285 & $12 / 18 / 2001$ & 03:20:00AM & 1,243 & 15.9 & \\
\hline 286 & $12 / 18 / 2001$ & 03:25:00AM & 1,240 & 15.9 & \\
\hline 287 & $12 / 18 / 2001$ & 03:30:00AM & 1,250 & 15.5 & \\
\hline 288 & $12 / 18 / 2001$ & 03:35:00AM & 1,255 & 15.6 & \\
\hline 289 & $12 / 18 / 2001$ & 03:40:00AM & 1,254 & 15.7 & \\
\hline 290 & $12 / 18 / 2001$ & 03:45:00AM & 1,255 & 15.8 & \\
\hline 291 & $12 / 18 / 2001$ & 03:50:00AM & 1,256 & 15.9 & \\
\hline 292 & $12 / 18 / 2001$ & 03:55:00AM & 1,255 & 15.8 & \\
\hline 293 & $12 / 18 / 2001$ & 04:00:00AM & 1,253 & 15.9 & \\
\hline 294 & $12 / 18 / 2001$ & 04:05:00AM & 1,259 & 15.8 & \\
\hline 295 & $12 / 18 / 2001$ & 04:10:00AM & 1,254 & 15.7 & \\
\hline 296 & $12 / 18 / 2001$ & 04:15:00AM & 1,254 & 15.6 & \\
\hline 297 & $12 / 18 / 2001$ & 04:20:00AM & 1,259 & 15.3 & \\
\hline
\end{tabular}

B.9 


\begin{tabular}{|c|c|c|c|c|c|}
\hline $\begin{array}{l}\text { Sample } \\
\text { Number } \\
\end{array}$ & Date & Time & $\begin{array}{c}\text { Conductivity } \\
(\mu \mathrm{S} / \mathrm{cm})\end{array}$ & $\begin{array}{c}\text { Temperature } \\
\left({ }^{\circ} \mathrm{C}\right) \\
\end{array}$ & Notes \\
\hline 298 & $12 / 18 / 2001$ & 04:25:00AM & 1,257 & 14.9 & \\
\hline 299 & $12 / 18 / 2001$ & 04:30:00AM & 1,259 & 14.6 & \\
\hline 300 & $12 / 18 / 2001$ & 04:35:00AM & 1,258 & 14.6 & \\
\hline 301 & $12 / 18 / 2001$ & 04:40:00AM & 1,258 & 14.8 & \\
\hline 302 & $12 / 18 / 2001$ & 04:45:00AM & 1,268 & 14.9 & \\
\hline 303 & $12 / 18 / 2001$ & 04:50:00AM & 1,255 & 15.2 & \\
\hline 304 & $12 / 18 / 2001$ & 04:55:00AM & 1,265 & 15.4 & \\
\hline 305 & $12 / 18 / 2001$ & 05:00:00AM & 1,267 & 15.7 & \\
\hline 306 & $12 / 18 / 2001$ & 05:05:00AM & 1,263 & 15.6 & \\
\hline 307 & $12 / 18 / 2001$ & 05:10:00AM & 1,260 & 15.5 & \\
\hline 308 & $12 / 18 / 2001$ & 05:15:00AM & 1,261 & 15.5 & \\
\hline 309 & $12 / 18 / 2001$ & 05:20:00AM & 1,259 & 15.4 & \\
\hline 310 & $12 / 18 / 2001$ & 05:25:00AM & 1,260 & 15.1 & \\
\hline 311 & $12 / 18 / 2001$ & 05:30:00AM & 1,256 & 15 & \\
\hline 312 & $12 / 18 / 2001$ & 05:35:00AM & 1,257 & 14.6 & \\
\hline 313 & $12 / 18 / 2001$ & 05:40:00AM & 1,264 & 14.5 & \\
\hline 314 & $12 / 18 / 2001$ & 05:45:00AM & 1,265 & 14.3 & \\
\hline 315 & $12 / 18 / 2001$ & 05:50:00AM & 1,264 & 14.4 & \\
\hline 316 & $12 / 18 / 2001$ & 05:55:00AM & 1,268 & 14.3 & \\
\hline 317 & $12 / 18 / 2001$ & 06:00:00AM & 1,265 & 14.5 & \\
\hline 318 & $12 / 18 / 2001$ & 06:05:00AM & 1,255 & 14.6 & \\
\hline 319 & $12 / 18 / 2001$ & 06:10:00AM & 1,260 & 14.5 & \\
\hline 320 & $12 / 18 / 2001$ & 06:15:00AM & 1,266 & 14.5 & \\
\hline 321 & $12 / 18 / 2001$ & 06:20:00AM & 1,259 & 14.6 & \\
\hline 322 & $12 / 18 / 2001$ & 06:25:00AM & 1,257 & 14.7 & \\
\hline 323 & $12 / 18 / 2001$ & 06:30:00AM & 1,261 & 14.8 & \\
\hline 324 & $12 / 18 / 2001$ & 06:35:00AM & 1,261 & 14.9 & \\
\hline 325 & $12 / 18 / 2001$ & 06:40:00AM & 1,256 & 14.6 & \\
\hline 326 & $12 / 18 / 2001$ & 06:45:00AM & 1,263 & 14.5 & \\
\hline 327 & $12 / 18 / 2001$ & 06:50:00AM & 1,263 & 15 & \\
\hline 328 & $12 / 18 / 2001$ & 06:55:00AM & 1,260 & 15 & \\
\hline 329 & $12 / 18 / 2001$ & 07:00:00AM & 1,258 & 15.2 & \\
\hline 330 & $12 / 18 / 2001$ & 07:05:00AM & 1,256 & 14.8 & \\
\hline 331 & $12 / 18 / 2001$ & 07:10:00AM & 1,271 & 14.6 & \\
\hline 332 & $12 / 18 / 2001$ & 07:15:00AM & 1,270 & 14.5 & \\
\hline 333 & $12 / 18 / 2001$ & 07:20:00AM & 1,261 & 14.8 & \\
\hline 334 & $12 / 18 / 2001$ & 07:25:00AM & 1,267 & 15 & \\
\hline 335 & $12 / 18 / 2001$ & 07:30:00AM & 1,263 & 15.2 & \\
\hline 336 & $12 / 18 / 2001$ & 07:35:00AM & 1,260 & 15.4 & \\
\hline 337 & $12 / 18 / 2001$ & 07:40:00AM & 1,269 & 15.1 & \\
\hline 338 & $12 / 18 / 2001$ & 07:45:00AM & 1,265 & 15.4 & \\
\hline 339 & $12 / 18 / 2001$ & 07:50:00AM & 1,260 & 15.6 & \\
\hline 340 & $12 / 18 / 2001$ & 07:55:00AM & 1,264 & 15.5 & \\
\hline
\end{tabular}




\begin{tabular}{|c|c|c|c|c|c|}
\hline $\begin{array}{l}\text { Sample } \\
\text { Number }\end{array}$ & Date & Time & $\begin{array}{l}\text { Conductivity } \\
(\mu \mathrm{S} / \mathrm{cm})\end{array}$ & $\begin{array}{c}\text { Temperature } \\
\left({ }^{\circ} \mathrm{C}\right)\end{array}$ & Notes \\
\hline 341 & $12 / 18 / 2001$ & 08:00:00AM & 1,259 & 15.5 & \\
\hline 342 & $12 / 18 / 2001$ & 08:05:00AM & 1,261 & 15.5 & \\
\hline 343 & $12 / 18 / 2001$ & 08:10:00AM & 1,264 & 15.5 & \\
\hline 344 & $12 / 18 / 2001$ & 08:15:00AM & 1,265 & 15.3 & \\
\hline 345 & $12 / 18 / 2001$ & 08:20:00AM & 1,260 & 14.9 & \\
\hline 346 & $12 / 18 / 2001$ & 08:25:00AM & 1,261 & 14.9 & \\
\hline 347 & $12 / 18 / 2001$ & 08:30:00AM & 1,261 & 15.1 & \\
\hline 348 & $12 / 18 / 2001$ & 08:35:00AM & 1,267 & 15.1 & \\
\hline 349 & $12 / 18 / 2001$ & 08:40:00AM & 1,260 & 15.1 & \\
\hline 350 & $12 / 18 / 2001$ & 08:45:00AM & 1,259 & 14.9 & \\
\hline 351 & $12 / 18 / 2001$ & 08:50:00AM & 1,266 & 15 & \\
\hline 352 & $12 / 18 / 2001$ & 08:55:00AM & 1,265 & 15.1 & \\
\hline 353 & $12 / 18 / 2001$ & 09:00:00AM & 1,265 & 15.1 & \\
\hline 354 & $12 / 18 / 2001$ & 09:05:00AM & 1,261 & 15.8 & \\
\hline 355 & $12 / 18 / 2001$ & 09:10:00AM & 1,262 & 15.7 & \\
\hline 356 & $12 / 18 / 2001$ & 09:15:00AM & 1,361 & 15.5 & \\
\hline 357 & $12 / 18 / 2001$ & 09:20:00AM & 1,245 & 15.4 & \\
\hline 358 & $12 / 18 / 2001$ & 09:25:00AM & 1,242 & 15.6 & \\
\hline 359 & $12 / 18 / 2001$ & 09:30:00AM & 1,249 & 15.8 & \\
\hline 360 & $12 / 18 / 2001$ & 09:35:00AM & 1,251 & 15.8 & \\
\hline 361 & $12 / 18 / 2001$ & 09:40:00AM & 1,254 & 16 & \\
\hline 362 & $12 / 18 / 2001$ & 09:45:00AM & 1,246 & 15.7 & \\
\hline 363 & $12 / 18 / 2001$ & 09:50:00AM & 1,252 & 15.8 & \\
\hline 364 & $12 / 18 / 2001$ & 09:55:00AM & 1,246 & 15.8 & \\
\hline 365 & $12 / 18 / 2001$ & 10:00:00AM & 1,253 & 15.8 & \\
\hline 366 & $12 / 18 / 2001$ & 10:05:00AM & 1,252 & 16 & \\
\hline 367 & $12 / 18 / 2001$ & 10:10:00AM & 1,251 & 16.3 & \\
\hline 368 & $12 / 18 / 2001$ & 10:15:00AM & 1,254 & 16 & \\
\hline 369 & $12 / 18 / 2001$ & 10:20:00AM & 1,249 & 15.7 & \\
\hline 370 & $12 / 18 / 2001$ & 10:25:00AM & 1,254 & 16.1 & \\
\hline 371 & $12 / 18 / 2001$ & 10:30:00AM & 1,255 & 16.2 & \\
\hline 372 & $12 / 18 / 2001$ & 10:35:00AM & 1,250 & 16.2 & \\
\hline 373 & $12 / 18 / 2001$ & 10:40:00AM & 1,252 & 16 & \\
\hline 374 & $12 / 18 / 2001$ & 10:45:00AM & 1,256 & 16 & \\
\hline 375 & $12 / 18 / 2001$ & 10:50:00AM & 1,252 & 16.3 & \\
\hline 376 & $12 / 18 / 2001$ & 10:55:00AM & 1,256 & 16.3 & \\
\hline 377 & $12 / 18 / 2001$ & 11:00:00AM & 1,252 & 16.3 & \\
\hline 378 & $12 / 18 / 2001$ & 11:05:00AM & 1,252 & 16.3 & \\
\hline 379 & $12 / 18 / 2001$ & 11:10:00AM & 1,257 & 16.2 & \\
\hline 380 & $12 / 18 / 2001$ & 11:15:00AM & 1,256 & 16.3 & \\
\hline 381 & $12 / 18 / 2001$ & 11:26:56AM & 2,710 & 19.9 & 2,764 $\mu \mathrm{S}$ calibration standard \\
\hline 382 & $12 / 18 / 2001$ & 11:28:51AM & 447 & 19.8 & $447 \mu \mathrm{S}$ calibration standard \\
\hline 383 & $12 / 18 / 2001$ & 11:40:00AM & 1,303 & 15.9 & \\
\hline
\end{tabular}

B.11 


\begin{tabular}{|c|c|c|c|c|c|}
\hline $\begin{array}{l}\text { Sample } \\
\text { Number } \\
\end{array}$ & Date & Time & $\begin{array}{c}\text { Conductivity } \\
(\mu \mathrm{S} / \mathrm{cm})\end{array}$ & $\begin{array}{c}\text { Temperature } \\
\left({ }^{\circ} \mathrm{C}\right) \\
\end{array}$ & Notes \\
\hline 384 & $12 / 18 / 2001$ & 11:50:00AM & 1,318 & 15.7 & \\
\hline 385 & $12 / 18 / 2001$ & 12:00:00PM & 1,277 & 15 & \\
\hline 386 & $12 / 18 / 2001$ & 12:10:00PM & 1,280 & 14.5 & \\
\hline 387 & $12 / 18 / 2001$ & 12:20:00PM & 1,270 & 14.7 & \\
\hline 388 & $12 / 18 / 2001$ & $12: 30: 00 \mathrm{PM}$ & 1,276 & 14.9 & \\
\hline 389 & $12 / 18 / 2001$ & 12:40:00PM & 1,281 & 15 & \\
\hline 390 & $12 / 18 / 2001$ & 12:50:00PM & 1,275 & 15.4 & \\
\hline 391 & $12 / 18 / 2001$ & 01:00:00PM & 1,281 & 15.8 & \\
\hline 392 & $12 / 18 / 2001$ & 01:10:00PM & 1,277 & 16.4 & \\
\hline 393 & $12 / 18 / 2001$ & 01:20:00PM & 1,278 & 16.1 & \\
\hline 394 & $12 / 18 / 2001$ & 01:30:00PM & 1,274 & 15.8 & \\
\hline 395 & $12 / 18 / 2001$ & 01:40:00PM & 1,277 & 15.7 & \\
\hline 396 & $12 / 18 / 2001$ & 01:50:00PM & 1,275 & 16.4 & \\
\hline 397 & $12 / 18 / 2001$ & 02:00:00PM & 1,279 & 16 & \\
\hline 398 & $12 / 18 / 2001$ & 02:10:00PM & 1,282 & 16.2 & \\
\hline 399 & $12 / 18 / 2001$ & 02:20:00PM & 1,279 & 16.1 & \\
\hline 400 & $12 / 18 / 2001$ & 02:30:00PM & 1,282 & 16 & \\
\hline 401 & $12 / 18 / 2001$ & 02:40:00PM & 1,286 & 15.9 & \\
\hline 402 & $12 / 18 / 2001$ & 02:50:00PM & 1,283 & 16 & \\
\hline 403 & $12 / 18 / 2001$ & 03:00:00PM & 1,282 & 16 & \\
\hline 404 & $12 / 18 / 2001$ & 03:10:00PM & 1,277 & 16.1 & \\
\hline 405 & $12 / 18 / 2001$ & 03:20:00PM & 1,279 & 16.2 & \\
\hline 406 & $12 / 18 / 2001$ & 03:30:00PM & 1,280 & 16.2 & \\
\hline 407 & $12 / 18 / 2001$ & 03:40:00PM & 1,279 & 16.8 & \\
\hline 408 & $12 / 18 / 2001$ & 03:50:00PM & 1,278 & 16.8 & \\
\hline 409 & $12 / 18 / 2001$ & 04:00:00PM & 1,281 & 16.5 & \\
\hline 410 & $12 / 18 / 2001$ & 04:10:00PM & 1,285 & 16.1 & \\
\hline 411 & $12 / 18 / 2001$ & 04:20:00PM & 1,287 & 16.1 & \\
\hline 412 & $12 / 18 / 2001$ & 04:30:00PM & 1,286 & 15.8 & \\
\hline 413 & $12 / 18 / 2001$ & 04:40:00PM & 1,278 & 15.8 & \\
\hline 414 & $12 / 18 / 2001$ & 04:50:00PM & 1,288 & 15.9 & \\
\hline 415 & $12 / 18 / 2001$ & 05:00:00PM & 1,288 & 15.8 & \\
\hline 416 & $12 / 18 / 2001$ & 05:10:00PM & 1,276 & 16.3 & \\
\hline 417 & $12 / 18 / 2001$ & 05:20:00PM & 1,275 & 16.1 & \\
\hline 418 & $12 / 18 / 2001$ & 05:30:00PM & 1,280 & 15.9 & \\
\hline 419 & $12 / 18 / 2001$ & 05:40:00PM & 1,276 & 15.5 & \\
\hline 420 & $12 / 18 / 2001$ & 05:50:00PM & 1,283 & 15.5 & \\
\hline 421 & $12 / 18 / 2001$ & 06:00:00PM & 1,277 & 16.1 & \\
\hline 422 & $12 / 18 / 2001$ & 06:10:00PM & 1,291 & 15.5 & \\
\hline 423 & $12 / 18 / 2001$ & 06:20:00PM & 1,281 & 15.6 & \\
\hline 424 & $12 / 18 / 2001$ & 06:30:00PM & 1,280 & 15.7 & \\
\hline 425 & $12 / 18 / 2001$ & 06:40:00PM & 1,275 & 15.5 & \\
\hline 426 & $12 / 18 / 2001$ & 06:50:00PM & 1,281 & 15.7 & \\
\hline
\end{tabular}

B.12 


\begin{tabular}{|c|c|c|c|c|c|}
\hline $\begin{array}{c}\text { Sample } \\
\text { Number } \\
\end{array}$ & Date & Time & $\begin{array}{c}\text { Conductivity } \\
(\mu \mathrm{S} / \mathrm{cm})\end{array}$ & $\begin{array}{c}\text { Temperature } \\
\left({ }^{\circ} \mathrm{C}\right) \\
\end{array}$ & Notes \\
\hline 427 & $12 / 18 / 2001$ & 07:00:00PM & 1,276 & 15.7 & \\
\hline 428 & $12 / 18 / 2001$ & 07:10:00PM & 1,283 & 15.7 & \\
\hline 429 & $12 / 18 / 2001$ & 07:20:00PM & 1,279 & 15.8 & \\
\hline 430 & $12 / 18 / 2001$ & 07:30:00PM & 1,277 & 15.9 & \\
\hline 431 & $12 / 18 / 2001$ & 07:40:00PM & 1,277 & 15.6 & \\
\hline 432 & $12 / 18 / 2001$ & 07:50:00PM & 1,275 & 15.6 & \\
\hline 433 & $12 / 18 / 2001$ & 08:00:00PM & 1,277 & 16 & \\
\hline 434 & $12 / 18 / 2001$ & 08:10:00PM & 1,281 & 15.7 & \\
\hline 435 & $12 / 18 / 2001$ & 08:20:00PM & 1,274 & 16.4 & \\
\hline 436 & $12 / 18 / 2001$ & 08:30:00PM & 1,275 & 16.2 & \\
\hline 437 & $12 / 18 / 2001$ & 08:40:00PM & 1,269 & 16.2 & \\
\hline 438 & $12 / 18 / 2001$ & 08:50:00PM & 1,271 & 15.4 & \\
\hline 439 & $12 / 18 / 2001$ & 09:00:00PM & 1,275 & 15.8 & \\
\hline 440 & $12 / 18 / 2001$ & 09:10:00PM & 1,277 & 15.9 & \\
\hline 441 & $12 / 18 / 2001$ & 09:20:00PM & 1,277 & 15.4 & \\
\hline 442 & $12 / 18 / 2001$ & 09:30:00PM & 1,276 & 15.7 & \\
\hline 443 & $12 / 18 / 2001$ & 09:40:00PM & 1,280 & 15.1 & \\
\hline 444 & $12 / 18 / 2001$ & 09:50:00PM & 1,280 & 15.4 & \\
\hline 445 & $12 / 18 / 2001$ & 10:00:00PM & 1,280 & 15.4 & \\
\hline 446 & $12 / 18 / 2001$ & 10:10:00PM & 1,274 & 15.2 & \\
\hline 447 & $12 / 18 / 2001$ & 10:20:00PM & 1,281 & 15.2 & \\
\hline 448 & $12 / 18 / 2001$ & 10:30:00PM & 1,277 & 14.8 & \\
\hline 449 & $12 / 18 / 2001$ & 10:40:00PM & 1,281 & 14.7 & \\
\hline 450 & $12 / 18 / 2001$ & 10:50:00PM & 1,286 & 14.6 & \\
\hline 451 & $12 / 18 / 2001$ & 11:00:00PM & 1,284 & 14.9 & \\
\hline 452 & $12 / 18 / 2001$ & 11:10:00PM & 1,283 & 14.3 & \\
\hline 453 & $12 / 18 / 2001$ & 11:20:00PM & 1,280 & 15.1 & \\
\hline 454 & $12 / 18 / 2001$ & 11:30:00PM & 1,279 & 14.8 & \\
\hline 455 & $12 / 18 / 2001$ & 11:40:00PM & 1,286 & 14.9 & \\
\hline 456 & $12 / 18 / 2001$ & 11:50:00PM & 1,281 & 14.9 & \\
\hline 457 & $12 / 19 / 2001$ & 12:00:00AM & 1,281 & 15.1 & \\
\hline 458 & $12 / 19 / 2001$ & 12:10:00AM & 1,279 & 15.2 & \\
\hline 459 & $12 / 19 / 2001$ & 12:20:00AM & 1,288 & 14.9 & \\
\hline 460 & $12 / 19 / 2001$ & 12:30:00AM & 1,284 & 14.5 & \\
\hline 461 & $12 / 19 / 2001$ & 12:40:00AM & 1,283 & 14.5 & \\
\hline 462 & $12 / 19 / 2001$ & 12:50:00AM & 1,289 & 15.5 & \\
\hline 463 & $12 / 19 / 2001$ & 01:00:00AM & 1,367 & 15 & \\
\hline 464 & $12 / 19 / 2001$ & 01:10:00AM & 1,251 & 15.3 & \\
\hline 465 & $12 / 19 / 2001$ & 01:20:00AM & 1,313 & 15.5 & \\
\hline 466 & $12 / 19 / 2001$ & 01:30:00AM & 1,300 & 15.2 & \\
\hline 467 & $12 / 19 / 2001$ & 01:40:00AM & 1,293 & 14.7 & \\
\hline 468 & $12 / 19 / 2001$ & 01:50:00AM & 1,326 & 15.3 & \\
\hline 469 & $12 / 19 / 2001$ & 02:00:00AM & 1,205 & 15.1 & \\
\hline
\end{tabular}

B.13 


\begin{tabular}{|c|c|c|c|c|c|}
\hline $\begin{array}{c}\text { Sample } \\
\text { Number } \\
\end{array}$ & Date & Time & $\begin{array}{c}\text { Conductivity } \\
(\mu \mathrm{S} / \mathrm{cm})\end{array}$ & $\begin{array}{c}\text { Temperature } \\
\left({ }^{\circ} \mathrm{C}\right) \\
\end{array}$ & Notes \\
\hline 470 & $12 / 19 / 2001$ & 02:10:00AM & 1,240 & 15.5 & \\
\hline 471 & $12 / 19 / 2001$ & 02:20:00AM & 1,248 & 15.1 & \\
\hline 472 & $12 / 19 / 2001$ & 02:30:00AM & 1,255 & 15.1 & \\
\hline 473 & $12 / 19 / 2001$ & 02:40:00AM & 1,250 & 14.8 & \\
\hline 474 & $12 / 19 / 2001$ & 02:50:00AM & 1,285 & 14.8 & \\
\hline 475 & $12 / 19 / 2001$ & 03:00:00AM & 1,279 & 14.2 & \\
\hline 476 & $12 / 19 / 2001$ & 03:10:00AM & 1,288 & 14.3 & \\
\hline 477 & $12 / 19 / 2001$ & 03:20:00AM & 1,283 & 14.3 & \\
\hline 478 & $12 / 19 / 2001$ & 03:30:00AM & 1,280 & 14.7 & \\
\hline 479 & $12 / 19 / 2001$ & 03:40:00AM & 1,281 & 13.9 & \\
\hline 480 & $12 / 19 / 2001$ & 03:50:00AM & 1,282 & 13.4 & \\
\hline 481 & $12 / 19 / 2001$ & 04:00:00AM & 1,284 & 13.9 & \\
\hline 482 & $12 / 19 / 2001$ & 04:10:00AM & 1,278 & 13.7 & \\
\hline 483 & $12 / 19 / 2001$ & 04:20:00AM & 1,283 & 13.9 & \\
\hline 484 & $12 / 19 / 2001$ & 04:30:00AM & 1,282 & 13.6 & \\
\hline 485 & $12 / 19 / 2001$ & 04:40:00AM & 1,279 & 14.2 & \\
\hline 486 & $12 / 19 / 2001$ & 04:50:00AM & 1,289 & 14.4 & \\
\hline 487 & $12 / 19 / 2001$ & 05:00:00AM & 1,281 & 14.4 & \\
\hline 488 & $12 / 19 / 2001$ & 05:10:00AM & 1,281 & 14.9 & \\
\hline 489 & $12 / 19 / 2001$ & 05:20:00AM & 1,282 & 14.9 & \\
\hline 490 & $12 / 19 / 2001$ & 05:30:00AM & 1,282 & 14.3 & \\
\hline 491 & $12 / 19 / 2001$ & 05:40:00AM & 1,292 & 14.4 & \\
\hline 492 & $12 / 19 / 2001$ & 05:50:00AM & 1,282 & 14.2 & \\
\hline 493 & $12 / 19 / 2001$ & 06:00:00AM & 1,277 & 14.2 & \\
\hline 494 & $12 / 19 / 2001$ & 06:10:00AM & 1,287 & 14.6 & \\
\hline 495 & $12 / 19 / 2001$ & 06:20:00AM & 1,286 & 14.6 & \\
\hline 496 & $12 / 19 / 2001$ & 06:30:00AM & 1,282 & 13.5 & \\
\hline 497 & $12 / 19 / 2001$ & 06:40:00AM & 1,283 & 13.1 & \\
\hline 498 & $12 / 19 / 2001$ & 06:50:00AM & 1,286 & 13.3 & \\
\hline 499 & $12 / 19 / 2001$ & 07:00:00AM & 1,287 & 13 & \\
\hline 500 & $12 / 19 / 2001$ & 07:10:00AM & 1,281 & 12.8 & \\
\hline 501 & $12 / 19 / 2001$ & 07:20:00AM & 1,282 & 13.3 & \\
\hline 502 & $12 / 19 / 2001$ & 07:30:00AM & 1,283 & 13.4 & \\
\hline 503 & $12 / 19 / 2001$ & 07:40:00AM & 1,285 & 14.7 & \\
\hline 504 & $12 / 19 / 2001$ & 07:50:00AM & 1,279 & 14.7 & \\
\hline 505 & $12 / 19 / 2001$ & 08:00:00AM & 1,282 & 15 & \\
\hline 506 & $12 / 19 / 2001$ & 08:10:00AM & 1,284 & 15.6 & \\
\hline 507 & $12 / 19 / 2001$ & 08:20:00AM & 1,281 & 15.7 & \\
\hline 508 & $12 / 19 / 2001$ & 08:30:00AM & 1,281 & 15.2 & \\
\hline 509 & $12 / 19 / 2001$ & 08:40:00AM & 1,277 & 15.9 & \\
\hline 510 & $12 / 19 / 2001$ & 08:50:00AM & 1,278 & 15.9 & \\
\hline 511 & $12 / 19 / 2001$ & 09:00:00AM & 1,277 & 15.9 & \\
\hline 512 & $12 / 19 / 2001$ & 09:10:00AM & 1,275 & 16.3 & \\
\hline
\end{tabular}

\section{B.14}




\begin{tabular}{|c|c|c|c|c|c|}
\hline $\begin{array}{c}\text { Sample } \\
\text { Number } \\
\end{array}$ & Date & Time & $\begin{array}{c}\text { Conductivity } \\
(\mu \mathrm{S} / \mathrm{cm})\end{array}$ & $\begin{array}{c}\text { Temperature } \\
\left({ }^{\circ} \mathrm{C}\right) \\
\end{array}$ & Notes \\
\hline 513 & $12 / 19 / 2001$ & 09:20:00AM & 1,275 & 16.5 & \\
\hline 514 & $12 / 19 / 2001$ & 09:30:00AM & 1,275 & 16.6 & \\
\hline 515 & $12 / 19 / 2001$ & 09:40:00AM & 1,273 & 16.6 & \\
\hline 516 & $12 / 19 / 2001$ & 09:50:00AM & 1,270 & 16.6 & \\
\hline 517 & $12 / 19 / 2001$ & 10:00:00AM & 1,269 & 16.7 & \\
\hline 518 & $12 / 19 / 2001$ & 10:10:00AM & 1,264 & 16.6 & \\
\hline 519 & $12 / 19 / 2001$ & 10:20:00AM & 1,272 & 16.6 & \\
\hline 520 & $12 / 19 / 2001$ & 10:30:00AM & 1,271 & 16.3 & \\
\hline 521 & $12 / 19 / 2001$ & 10:40:00AM & 1,267 & 16.5 & \\
\hline 522 & $12 / 19 / 2001$ & 10:50:00AM & 1,266 & 16.6 & \\
\hline 523 & $12 / 19 / 2001$ & 11:00:00AM & 1,270 & 16.4 & \\
\hline 524 & $12 / 19 / 2001$ & 11:10:00AM & 1,276 & 16.6 & \\
\hline 525 & $12 / 19 / 2001$ & 11:20:00AM & 1,269 & 17 & \\
\hline 526 & $12 / 19 / 2001$ & 11:30:00AM & 1,268 & 15.9 & \\
\hline 527 & $12 / 19 / 2001$ & 11:40:00AM & 1,267 & 16.5 & \\
\hline 528 & $12 / 19 / 2001$ & 11:50:00AM & 1,274 & 16.5 & \\
\hline 529 & $12 / 19 / 2001$ & 12:00:00PM & 1,268 & 16.8 & \\
\hline 530 & $12 / 19 / 2001$ & 12:10:00PM & 1,273 & 16.3 & \\
\hline 531 & $12 / 19 / 2001$ & 12:20:00PM & 1,270 & 16.6 & \\
\hline 532 & $12 / 19 / 2001$ & 12:30:00PM & 1,272 & 15.9 & \\
\hline 533 & $12 / 19 / 2001$ & 12:40:00PM & 1,222 & 16.3 & \\
\hline 534 & $12 / 19 / 2001$ & 12:50:00PM & 1,416 & 16.8 & \\
\hline 535 & $12 / 19 / 2001$ & 01:00:00PM & 1,284 & 16.3 & \\
\hline 536 & $12 / 19 / 2001$ & 01:10:00PM & 1,267 & 16.5 & \\
\hline 537 & $12 / 19 / 2001$ & 01:20:00PM & 1,274 & 16.4 & \\
\hline 538 & $12 / 19 / 2001$ & 01:30:00PM & 1,273 & 16.3 & \\
\hline 539 & $12 / 19 / 2001$ & 01:40:00PM & 1,272 & 16.5 & \\
\hline 540 & $12 / 19 / 2001$ & 01:50:00PM & 1,268 & 16.3 & \\
\hline 541 & $12 / 19 / 2001$ & 02:00:00PM & 1,274 & 16.1 & \\
\hline 542 & $12 / 19 / 2001$ & 02:10:00PM & 1,268 & 16.1 & \\
\hline 543 & $12 / 19 / 2001$ & 02:20:00PM & 1,270 & 15.8 & \\
\hline 544 & $12 / 19 / 2001$ & 02:30:00PM & 1,267 & 15.8 & \\
\hline 545 & $12 / 19 / 2001$ & 02:40:00PM & 1,275 & 15.6 & \\
\hline 546 & $12 / 19 / 2001$ & 02:50:00PM & 1,268 & 15.5 & \\
\hline 547 & $12 / 19 / 2001$ & 03:00:00PM & 1,274 & 15.2 & \\
\hline 548 & $12 / 19 / 2001$ & 03:10:00PM & 1,273 & 15.1 & \\
\hline 549 & $12 / 19 / 2001$ & 03:20:00PM & 1,270 & 15.4 & \\
\hline 550 & $12 / 19 / 2001$ & 03:30:00PM & 1,271 & 15.7 & \\
\hline 551 & $12 / 19 / 2001$ & 03:40:00PM & 1,280 & 15.5 & \\
\hline 552 & $12 / 19 / 2001$ & 03:50:00PM & 1,262 & 15.7 & \\
\hline 553 & $12 / 19 / 2001$ & 04:00:00PM & 1,277 & 15.6 & \\
\hline 554 & $12 / 19 / 2001$ & 04:10:00PM & 1,272 & 15.5 & \\
\hline 555 & $12 / 19 / 2001$ & 04:20:00PM & 1,279 & 15.5 & \\
\hline
\end{tabular}

B.15 


\begin{tabular}{|c|c|c|c|c|c|}
\hline $\begin{array}{l}\text { Sample } \\
\text { Number } \\
\end{array}$ & Date & Time & $\begin{array}{c}\text { Conductivity } \\
(\mu \mathrm{S} / \mathrm{cm})\end{array}$ & $\begin{array}{c}\text { Temperature } \\
\left({ }^{\circ} \mathrm{C}\right) \\
\end{array}$ & Notes \\
\hline 556 & $12 / 19 / 2001$ & 04:30:00PM & 1,280 & 15.2 & \\
\hline 557 & $12 / 19 / 2001$ & 04:40:00PM & 1,278 & 15.2 & \\
\hline 558 & $12 / 19 / 2001$ & 04:50:00PM & 1,281 & 14.8 & \\
\hline 559 & $12 / 19 / 2001$ & 05:00:00PM & 1,281 & 14.5 & \\
\hline 560 & $12 / 19 / 2001$ & 05:10:00PM & 1,282 & 14.5 & \\
\hline 561 & $12 / 19 / 2001$ & 05:20:00PM & 1,282 & 14.4 & \\
\hline 562 & $12 / 19 / 2001$ & 05:30:00PM & 1,278 & 14.4 & \\
\hline 563 & $12 / 19 / 2001$ & 05:40:00PM & 1,276 & 14.3 & \\
\hline 564 & $12 / 19 / 2001$ & 05:50:00PM & 1,280 & 14.4 & \\
\hline 565 & $12 / 19 / 2001$ & 06:00:00PM & 1,278 & 14.4 & \\
\hline 566 & $12 / 19 / 2001$ & 06:10:00PM & 1,274 & 14.3 & \\
\hline 567 & $12 / 19 / 2001$ & 06:20:00PM & 1,280 & 14.3 & \\
\hline 568 & $12 / 19 / 2001$ & 06:30:00PM & 1,284 & 14.5 & \\
\hline 569 & $12 / 19 / 2001$ & 06:40:00PM & 1,281 & 14.7 & \\
\hline 570 & $12 / 19 / 2001$ & 06:50:00PM & 1,277 & 14.5 & \\
\hline 571 & $12 / 19 / 2001$ & 07:00:00PM & 1,282 & 14.6 & \\
\hline 572 & $12 / 19 / 2001$ & 07:10:00PM & 1,279 & 14.5 & \\
\hline 573 & $12 / 19 / 2001$ & 07:20:00PM & 1,280 & 14.4 & \\
\hline 574 & $12 / 19 / 2001$ & 07:30:00PM & 1,288 & 14 & \\
\hline 575 & $12 / 19 / 2001$ & 07:40:00PM & 1,284 & 14.4 & \\
\hline 576 & $12 / 19 / 2001$ & 07:50:00PM & 1,279 & 14.1 & \\
\hline 577 & $12 / 19 / 2001$ & 08:00:00PM & 1,283 & 13.7 & \\
\hline 578 & $12 / 19 / 2001$ & 08:10:00PM & 1,283 & 13.8 & \\
\hline 579 & $12 / 19 / 2001$ & 08:20:00PM & 1,277 & 13.8 & \\
\hline 580 & $12 / 19 / 2001$ & 08:30:00PM & 1,284 & 14 & \\
\hline 581 & $12 / 19 / 2001$ & 08:40:00PM & 1,282 & 13.9 & \\
\hline 582 & $12 / 19 / 2001$ & 08:50:00PM & 1,286 & 14 & \\
\hline 583 & $12 / 19 / 2001$ & 09:00:00PM & 1,285 & 14.4 & \\
\hline 584 & $12 / 19 / 2001$ & 09:10:00PM & 1,282 & 14 & \\
\hline 585 & $12 / 19 / 2001$ & 09:20:00PM & 1,286 & 14.1 & \\
\hline 586 & $12 / 19 / 2001$ & 09:30:00PM & 1,288 & 14.3 & \\
\hline 587 & $12 / 19 / 2001$ & 09:40:00PM & 1,287 & 14.4 & \\
\hline 588 & $12 / 19 / 2001$ & 09:50:00PM & 1,284 & 14.2 & \\
\hline 589 & $12 / 19 / 2001$ & 10:00:00PM & 1,286 & 13.9 & \\
\hline 590 & $12 / 19 / 2001$ & 10:10:00PM & 1,288 & 13.8 & \\
\hline 591 & $12 / 19 / 2001$ & 10:20:00PM & 1,290 & 13.9 & \\
\hline 592 & $12 / 19 / 2001$ & 10:30:00PM & 1,290 & 13.8 & \\
\hline 593 & $12 / 19 / 2001$ & 10:40:00PM & 1,293 & 13.9 & \\
\hline 594 & $12 / 19 / 2001$ & 10:50:00PM & 1,286 & 14 & \\
\hline 595 & $12 / 19 / 2001$ & 11:00:00PM & 1,290 & 14.2 & \\
\hline 596 & $12 / 19 / 2001$ & 11:10:00PM & 1,294 & 14.6 & \\
\hline 597 & $12 / 19 / 2001$ & 11:20:00PM & 1,287 & 14.7 & \\
\hline 598 & $12 / 19 / 2001$ & 11:30:00PM & 1,282 & 14.8 & \\
\hline
\end{tabular}

B.16 


\begin{tabular}{|c|c|c|c|c|c|}
\hline $\begin{array}{l}\text { Sample } \\
\text { Number } \\
\end{array}$ & Date & Time & $\begin{array}{c}\text { Conductivity } \\
(\mu \mathrm{S} / \mathrm{cm})\end{array}$ & $\begin{array}{c}\text { Temperature } \\
\left({ }^{\circ} \mathrm{C}\right) \\
\end{array}$ & Notes \\
\hline 599 & $12 / 19 / 2001$ & 11:40:00PM & 1,286 & 14.9 & \\
\hline 600 & $12 / 19 / 2001$ & 11:50:00PM & 1,304 & 15.4 & \\
\hline 601 & $12 / 19 / 2001$ & 12:00:00AM & 1,269 & 15.7 & \\
\hline 602 & $12 / 20 / 2001$ & 12:10:00AM & 1,219 & 15.3 & \\
\hline 603 & $12 / 20 / 2001$ & 12:20:00AM & 1,292 & 15.7 & \\
\hline 604 & $12 / 20 / 2001$ & 12:30:00AM & 1,273 & 15.8 & \\
\hline 605 & $12 / 20 / 2001$ & 12:40:00AM & 1,271 & 15.5 & \\
\hline 606 & $12 / 20 / 2001$ & 12:50:00AM & 1,272 & 15.5 & \\
\hline 607 & $12 / 20 / 2001$ & 01:00:00AM & 1,269 & 15.2 & \\
\hline 608 & $12 / 20 / 2001$ & 01:10:00AM & 1,269 & 15.1 & \\
\hline 609 & $12 / 20 / 2001$ & 01:20:00AM & 1,271 & 14.8 & \\
\hline 610 & $12 / 20 / 2001$ & 01:30:00AM & 1,274 & 14.9 & \\
\hline 611 & $12 / 20 / 2001$ & 01:40:00AM & 1,280 & 14.9 & \\
\hline 612 & $12 / 20 / 2001$ & 01:50:00AM & 1,270 & 15.2 & \\
\hline 613 & $12 / 20 / 2001$ & 02:00:00AM & 1,279 & 15.3 & \\
\hline 614 & $12 / 20 / 2001$ & 02:10:00AM & 1,273 & 15.3 & \\
\hline 615 & $12 / 20 / 2001$ & 02:20:00AM & 1,271 & 15.4 & \\
\hline 616 & $12 / 20 / 2001$ & 02:30:00AM & 1,268 & 15.4 & \\
\hline 617 & $12 / 20 / 2001$ & 02:40:00AM & 1,274 & 15 & \\
\hline 618 & $12 / 20 / 2001$ & 02:50:00AM & 1,269 & 14.4 & \\
\hline 619 & $12 / 20 / 2001$ & 03:00:00AM & 1,268 & 14.2 & \\
\hline 620 & $12 / 20 / 2001$ & 03:10:00AM & 1,275 & 14.4 & \\
\hline 621 & $12 / 20 / 2001$ & 03:20:00AM & 1,276 & 14.4 & \\
\hline 622 & $12 / 20 / 2001$ & 03:30:00AM & 1,280 & 14.5 & \\
\hline 623 & $12 / 20 / 2001$ & 03:40:00AM & 1,271 & 14.7 & \\
\hline 624 & $12 / 20 / 2001$ & 03:50:00AM & 1,275 & 14.8 & \\
\hline 625 & $12 / 20 / 2001$ & 04:00:00AM & 1,271 & 15.1 & \\
\hline 626 & $12 / 20 / 2001$ & 04:10:00AM & 1,277 & 15.3 & \\
\hline 627 & $12 / 20 / 2001$ & 04:20:00AM & 1,276 & 15.1 & \\
\hline 628 & $12 / 20 / 2001$ & 04:30:00AM & 1,272 & 15.2 & \\
\hline 629 & $12 / 20 / 2001$ & 04:40:00AM & 1,276 & 15.2 & \\
\hline 630 & $12 / 20 / 2001$ & 04:50:00AM & 1,276 & 15.2 & \\
\hline 631 & $12 / 20 / 2001$ & 05:00:00AM & 1,269 & 15.3 & \\
\hline 632 & $12 / 20 / 2001$ & 05:10:00AM & 1,273 & 15.2 & \\
\hline 633 & $12 / 20 / 2001$ & 05:20:00AM & 1,273 & 15.4 & \\
\hline 634 & $12 / 20 / 2001$ & 05:30:00AM & 1,279 & 15.2 & \\
\hline 635 & $12 / 20 / 2001$ & 05:40:00AM & 1,281 & 15 & \\
\hline 636 & $12 / 20 / 2001$ & 05:50:00AM & 1,274 & 15 & \\
\hline 637 & $12 / 20 / 2001$ & 06:00:00AM & 1,275 & 15.1 & \\
\hline 638 & $12 / 20 / 2001$ & 06:10:00AM & 1,277 & 15.2 & \\
\hline 639 & $12 / 20 / 2001$ & 06:20:00AM & 1,274 & 15.3 & \\
\hline 640 & $12 / 20 / 2001$ & 06:30:00AM & 1,275 & 15.1 & \\
\hline 641 & $12 / 20 / 2001$ & 06:40:00AM & 1,272 & 15.2 & \\
\hline
\end{tabular}




\begin{tabular}{|c|c|c|c|c|c|}
\hline $\begin{array}{l}\text { Sample } \\
\text { Number }\end{array}$ & Date & Time & $\begin{array}{c}\text { Conductivity } \\
(\mu \mathrm{S} / \mathrm{cm})\end{array}$ & $\begin{array}{c}\text { Temperature } \\
\left({ }^{\circ} \mathrm{C}\right) \\
\end{array}$ & Notes \\
\hline 642 & $12 / 20 / 2001$ & 06:50:00AM & 1,278 & 15.3 & \\
\hline 643 & $12 / 20 / 2001$ & 07:00:00AM & 1,281 & 15.1 & \\
\hline 644 & $12 / 20 / 2001$ & 07:10:00AM & 1,270 & 15.5 & \\
\hline 645 & $12 / 20 / 2001$ & 07:20:00AM & 1,277 & 15.4 & \\
\hline 646 & $12 / 20 / 2001$ & 07:30:00AM & 1,273 & 15.1 & \\
\hline 647 & $12 / 20 / 2001$ & 07:40:00AM & 1,272 & 15 & \\
\hline 648 & $12 / 20 / 2001$ & 07:50:00AM & 1,270 & 15.2 & \\
\hline 649 & $12 / 20 / 2001$ & 08:00:00AM & 1,276 & 15.1 & \\
\hline 650 & $12 / 20 / 2001$ & 08:10:00AM & 1,279 & 15.1 & \\
\hline 651 & $12 / 20 / 2001$ & 08:20:00AM & 1,275 & 15.2 & \\
\hline 652 & $12 / 20 / 2001$ & 08:30:00AM & 1,278 & 15.4 & \\
\hline 653 & $12 / 20 / 2001$ & 08:40:00AM & 1,243 & 16 & \\
\hline 654 & $12 / 20 / 2001$ & 08:50:00AM & 1,262 & 13.9 & Pump off at 0854 \\
\hline 655 & $12 / 20 / 2001$ & 09:00:00AM & 0.03 & 17.5 & \\
\hline 656 & $12 / 20 / 2001$ & 09:10:00AM & 0.1 & 20 & \\
\hline 657 & $12 / 20 / 2001$ & 09:20:00AM & 0.11 & 21.1 & \\
\hline 658 & $12 / 20 / 2001$ & 09:30:00AM & 0.32 & 21.4 & \\
\hline 659 & $12 / 20 / 2001$ & 09:40:00AM & 0.29 & 21.2 & \\
\hline 660 & $12 / 20 / 2001$ & 09:50:00AM & 0.29 & 21 & \\
\hline 661 & $12 / 20 / 2001$ & 10:00:00AM & 0.28 & 21.1 & \\
\hline 662 & $12 / 20 / 2001$ & 10:10:00AM & 0.26 & 21.2 & \\
\hline
\end{tabular}




\section{Distribution}

No. of

Copies

OFFSITE

C. Abraham

U.S. General Accounting Office

825 Jadwin Ave., MSIN \#A1-80

Richland, WA 99352

Confederated Tribes and Bands of the

Yakama Indian Nation

Environmental Restoration Waste

Management Program

P.O. Box 151

Toppenish, WA 98948

Confederated Tribes of the Umatilla Indian

Reservation

P.O. Box 638

Pendleton, OR 97801

Nez Perce Tribe

Nez Perce Tribal Department of

Environmental Restoration and Waste

Management

P.O. Box 365

Lapwai, ID 83540

R. Patt

Oregon Water Resources

Water Resources Department

$55513^{\text {th }}$ Street Northeast

Salem, OR 97301
No. of

Copies

ONSITE

5 DOE Richland Operations Office

M. J. Furman

A5-13

J. G. Morse

A5-13

K. M. Thompson

A5-13

R. M. Yasek

H6-60

Public Reading Room

H2-53

3 CH2M HILL Hanford Group
A. J. Knepp
$\mathrm{H} 0-22$
F. M. Mann
$\mathrm{H} 0-22$
D. A. Myers
$\mathrm{H} 0-22$

6 Washington State Department of Ecology

M. J. Brown B5-18

S. L. Dahl B5-18

J. Caggiano B5-18

J. A. Hedges B5-18

A. D. Huckaby B5-18

S. McKinney (Olympia) B5-18

12 Pacific Northwest National Laboratory

C. J. Chou

K6-81

J. S. Fruchter

K6-96

D. G. Horton

K6-81

V. G. Johnson (4)

K6-96

S. P. Luttrell

K6-96

S. M. Narbutovskih

K6-96

R. M. Smith

K6-96

Hanford Technical Library (2) 